Studia Źródłoznawcze, t. LVI

p-ISSN 0081-7147

e-ISSN 2451-1331

Jakub ROGULSKI

Wydział Historyczny Uniwersytetu Jagiellońskiego

\title{
Genealogia rodu Sanguszków księcia Symeona Samuela Sanguszki*
}

Zarys treści: Genealogia rodu Sanguszków autorstwa Symeona Samuela Sanguszki (zm. 1638) znana jest z trzech rękopisów: oryginału oraz dwóch XVIII-wiecznych kopii. W pracy przedstawiono filiację znanych oraz ustalonych rękopisów, określono czas ich powstania, przeznaczenie oraz losy archiwalno-biblioteczne. Następnie ustalono źródła informacji: piśmiennictwo historyczne oraz pamięć zbiorową rodu, a na tej podstawie omówiono warsztat historyczny autora oraz kulturę pamięci jego familii. Na koniec zaprezentowano znaczenie genealogii dla tożsamości rodu Sanguszków oraz staropolskich badań genealogicznych. W aneksie zamieszczono edycję tekstu źródła, odtworzonego na podstawie staropolskich rękopisów oraz XIX-wiecznej transkrypcji oryginału.

\begin{abstract}
A genealogy of the Sanguszko Family produced by Symeon Samuel Sanguszko (died 1638) has been preserved in three versions: the original and its two $18^{\text {th }}$-century copies. The work contains the filiation of known and established manuscript texts, time of their creation, their purpose, and their archival and library history. Next, the sources of information are established: historical writings and the collective memory of the family, and based on this the historian's craft of the author and the memory culture of his family are discussed. And finally, the importance of the genealogy for the Sanguszko Family's identity and old-Polish genealogical studies is presented. The annex contains an edition of the genealogy text, reconstructed on the basis of old-Polish manuscripts and a nineteenth-century transcription of the original manuscript.
\end{abstract}

Słowa kluczowe: genealogia, świadomość genealogiczna, staropolskie piśmiennictwo historyczne, pamięć zbiorowa, tożsamość rodów szlacheckich, kultura rodów szlacheckich, Sanguszkowie, Rzeczpospolita Obojga Narodów

Keywords: genealogy, genealogical awareness, old-Polish historical writings, collective memory, identity of noble families, culture of noble families, the Sanguszkos, Polish-Lithuanian Commonwealth

W literaturze poświęconej dziejom książąt Sanguszków nietrudno natrafić na informację o rękopiśmiennej genealogii tego rodu ${ }^{1}$ sporządzonej w epoce staropolskiej. O dziełku tym wspomniał jako pierwszy Kasper Niesiecki w czwartym tomie herbarza Korona polska z 1743 r. $^{2}$ W drugiej połowie

* Praca powstała w ramach realizacji projektu badawczego pt. „Pamięć o dynastycznym pochodzeniu litewskich rodów książęcych: pisemne i wizualne formy jej utrwalania od XV do XVIII w.”, finansowego przez Narodowe Centrum Nauki na podstawie decyzji nr UMO-2013/11/N/HS3/04848.

${ }^{1}$ Terminu „ród” używam świadomie na określenie wspólnoty krewniaczej szerszej niż rodzina. Jako rodzinę rozumiem natomiast grupę osób wzajemnie od siebie zależnych, skupionych w jednym gospodarstwie domowym; za: C. Kuklo, Demografia Rzeczypospolitej przedrozbiorowej, Warszawa 2011, s. 354-356. W moim rozumieniu ród (dom, familia) jest strukturą mogącą obejmować więcej niż jedną rodzinę.

${ }^{2}$ K. Niesiecki, Korona polska przy złotej wolności starożytnemi rycerstwa polskiego i Wielkiego Księstwa Litewskiego klejnotami [...] ozdobiona, t. 4, Lwów 1743 [dalej: K. Niesiecki, Herbarz polski, t. 8, wyd. J.N. Bobrowicz, Lipsk 1841], s. 234, 236. 
XIX i na początku XX w. do genealogii tej odnosili się wielokrotnie badacze rodowodów kniaziów litewskich Giedyminowego pochodzenia ${ }^{3}$. W 1892 r. dziełkiem zainteresował się Marian Sokołowski na marginesie badań nad modlitewnikiem francuskim z 1505 r., w którym przez długi czas znajdował się najstarszy rękopis utworu ${ }^{4}$. Również we współczesnej literaturze odnajdujemy liczne wzmianki poświęcone staropolskiej genealogii Sanguszków. Garść uwag poświęcił jej Mirosław Nagielski w biogramie jej autora, księcia Symeona Samuela Sanguszki ${ }^{5}$. Z jego ustaleń korzystali następnie Krzysztof Syta i Jolanta Marszalska w swoich pracach na temat dziejów archiwum i biblioteki Sanguszków6. Szereg cennych ustaleń na temat losów najstarszego rękopisu poczyniła Jolanta Grala przy okazji prezentacji kolekcji Michała Marczaka z Archiwum Głównego Akt Dawnych w Warszawie, gdzie obecnie przechowywany jest ten zabytek ${ }^{7}$. Informacja o interesującej nas genealogii znalazła się nawet w popularnym Poczcie polskich rodów arystokratycznych autorstwa Teresy Zielińskiej ${ }^{8}$. Do treści dziełka odniosłem się także w kilku artykułach poświęconych świadomości genealogicznej książąt Sanguszków w epoce nowożytnej ${ }^{9}$.

Jak zatem widać, staropolska genealogia Sanguszków jest znana w historiografii od długiego czasu. Stan wiedzy na temat owego dzieła pozostaje jednak ubogi. Pomijając prace dotyczące biblioteczno-archiwalnych losów poszczególnych rękopisów, literatura ogranicza się do odnotowania faktu istnienia utworu, wskazania jego autora, a przede wszystkim - do wykazania fałszywości zawartego tam rodowodu. Genealogia bowiem wywodzi Sanguszków od księcia Lubarta Giedyminowicza, podczas gdy ród ten, jak dowiedli już w XIX w. badacze genealogii kniaziów litewskich, pochodził od księcia Fiodora, syna Olgierda ${ }^{10}$. „Bałamutność” ta wpłynęła na brak zainteresowania dziełkiem, jako że jego treść była bezużyteczna dla historyków zajmujących się odtworzeniem rodowodu familii.

Tymczasem wartość poznawcza genealogii Symeona Samuela tkwi nie w zawartych tam informacjach genealogicznych, chociaż i na tym polu dziełko niejednokrotnie okazuje się bezcenne, zwłaszcza dla późniejszych dziejów familii. W genealogii należy widzieć przede wszystkim znakomite źródło do badań nad pamięcią i kulturą historyczną magnaterii Rzeczypospolitej Obojga Narodów. Sporządzona osobiście przez jednego z reprezentantów rodu genealogia stanowi zapis wiedzy XVII-wiecznego magnata

\footnotetext{
${ }^{3}$ K. Stadnicki, Synowie Gedymina, t. 2: Lubart xiążę wołyński, Lwów 1853, s. 261; Encyklopedia powszechna, t. 22, wyd. S. Orgelbrand, Warszawa 1866, s. 909; T. Żychliński, Złota księga szlachty polskiej, t. 5, Poznań 1883, s. 296; Z.L. Radzimiński, Wstępne stowo do monografii xięcia Fedora Olgerdowicza Ratneńskiego i jego potomków, w: Sprawa początków rodu XX. Sanguszków, Lwów 1901, s. 3-4; Z.D. Kozicki, W sprawie rodowodu X. X. Sanguszków, w: tamże, s. 64; Monografia XX. Sanguszków oraz innych potomków Lubarta-Fedora Olgerdowicza x. ratneńskiego, t. 1, oprac. Z.L. Radzimiński, Lwów 1906, s. 2-3. Informacja o genealogii znalazła się także w niewydanym czwartym tomie monografii: Biblioteka Naukowa Akademii Nauk Ukrainy im. Wasyla Stefanyka we Lwowie [dalej: BNANU-Lw.], f. 91, k. 225. Ponadto B. Gorczak w katalogu rękopisów archiwum sławuckiego wskazał i opisał jednostkę archiwalną zawierającą dwa rękopisy dziełka; Katalog rękopisów archiwum XX. Sanguszków w Stawucie, oprac. B. Gorczak, Sławuta 1902, s. 179.

${ }^{4}$ M. Sokołowski, Miniatury włoskie Biblioteki Jagiellońskiej i modlitewnik francuski ks. Samuela Sanguszki w bibliotece dzikowskiej, Kraków 1892, s. 29-30.

5 M. Nagielski, Sanguszko Samuel Szymon (Symeon, Semen), w: PSB, t. 34, Wrocław 1992-1993, s. 512.

${ }^{6}$ K. Syta, Dzieje archiwum książąt Sanguszków, „Miscellanea Historico-Archivistica”, 11, 2000, s. 97-110; J.M. Marszalska, Biblioteka i archiwum Sanguszków. Zarys dziejów, Tarnów 2000, s. 21; zob. też: taż, Fundacje i życie religijne książat Lubartowiczów-Sanguszków linii koszyrskiej i kowelskiej na przełomie XVII i XVIII stulecia, w: Veritati serviens. Księa pamiątkowa Ojcu Profesorowi Januszowi Zbudniewkowi zp, Warszawa 2009, s. 203-224; Testamenty książat Lubartowiczów-Sanguszków. Wybór tekstów źródtowych z lat 1750-1876, wyd. J.M. Marszalska, W. Graczyk, Kraków 2011.

7 J. Grala, Kolekcja Michała Marczaka w zbiorach Archiwum Głównego Akt Dawnych, „Miscellanea Historico-Archivistica”, 4, 1994, s. 228-232.

${ }^{8}$ T. Zielińska, Poczet polskich rodów arystokratycznych, Warszawa 1997, s. 366-367.

9 J. Rogulski, Nowożytny ród szlachecki jako „,wspólnota pamięci”. Przypadek książat Sanguszków (XV-XVIII w.), Przegl. Hist., 108, 2017, nr 3, s. 520 n.; tenże, Memory of Social Elites. What Should not be Forgotten. The Case of the Lithuanian Princes in the Sixteenth to Eighteenth Centuries, „Court Historian”, 22, 2017, nr 2, s. 191-194; tenże, „Gutullae sanguinis Iagellonici”. Jagiellonian Identity among the Princes of Poland-Lithuania in the Early Modern Period, „Canadian-American Slavic Studies", 52, 2018, nr 2 (w druku).

10 J. Wolff, Kniaziowie litewsko-ruscy od końca czternastego wieku, Warszawa 1895, s. 422; J. Tęgowski, Pierwsze pokolenia Giedyminowiczów, Poznań-Wrocław 1999, s. 64.
} 
o dziejach własnej familii. Utwór ten bez wątpienia zasługuje na udostępnienie badaczom zajmującym się społeczno-kulturowymi dziejami stanu szlacheckiego Rzeczypospolitej ${ }^{11}$.

\title{
Autor, czas powstania, rękopisy
}

\begin{abstract}
Autor
Książę Symeon Samuel Sanguszko (zm. 1638) był przedstawicielem litewskiego rodu Giedyminowego pochodzenia, który wywodził się od księcia Sanguszki (zm. 1454/1463), syna Fiodora Olgierdowicza $^{12}$. Na znak swoich dynastycznych korzeni członkowie familii posługiwali się tytułem książęcym oraz herbem Pogoń ${ }^{13}$. Symeon Samuel reprezentował młodszą gałąź rodu, kowelską, nazywaną tak od położonego na Wołyniu Kowla, pierwotnego uposażenia linii. W 1543 r. pradziad autora genealogii, kniaź Wasyl Michałowicz, wymienił tę włość na położone w województwach witebskim i mińskim Smolany, Obolce i Horwol ${ }^{14}$. Odtąd Sanguszkowie kowelscy zamieszkiwali na wschodnich rubieżach Wielkiego Księstwa Litewskiego.

Symeon Samuel Sanguszko urodził się ok. 1583 r. ${ }^{15}$ Pierwszy w swojej linii katolik, jako młodzieniec był dworzaninem pokojowym Zygmunta III Wazy. Po opuszczeniu dworu podróżował po Europie. Odwiedził wiele krajów, w tym Niemcy, gdzie na uniwersytecie w Ingolsztadt podjął studia. Po powrocie do ojczyzny przez wiele lat służył w wojsku. W wojnach ze Szwecją i Moskwą zdobył sławę i uznanie, a nagrodą za zasługi były awanse urzędnicze i status senatorski. Książę piastował kolejno: chorążostwo orszańskie (1620), kasztelanię mścisławską (1620), kasztelanię witebską (1621) i wreszcie województwo witebskie $(1626)^{16}$. W latach 20 . XVII w. pełnił ponadto odpowiedzialne funkcje komisarza królewskiego oraz członka królewskiej komisji śledczej ${ }^{17}$. Zmarł w 1638 r. w Smolanach, a pochowany został w położonej nieopodal tej miejscowości rezydencji Sanguszków zwanej Biały Kowel.

Symeon Samuel Sanguszko był magnatem wyróżniającym się ze względu na swoje zdolności literackie i artystyczne oraz liczne zainteresowania. Próbował swoich sił w twórczości okazjonalnej, malował i rytował, głównie wizerunki świętych ${ }^{18}$. Pasjonował się nauką. W swojej rezydencji Biały Kowel

${ }^{11}$ Tworzenie genealogii rodów szlacheckich wydaje się zjawiskiem powszechnym w XVI-XVIII w. Sam Niesiecki wspomina w swoim herbarzu 50 dzieł tego rodzaju; zob. I. Dacka, „Korona polska” Kaspra Niesieckiego. Pomnik staropolskiego piśmiennictwa heraldycznego, Warszawa 2004, s. 77-81. Niemniej wśród polskich wydawnictw źródłowych nie odnajdujemy jak dotąd edycji typowej genealogii rodowej, prezentującej rodowód danego domu od jego początków aż po czasy współczesne autorowi.

${ }^{12}$ Zob. najważniejszą literaturę genealogiczną poświęconą Sanguszkom: J. Wolff, Kniaziowie, s. 422-455; Monografia XX. Sanguszków, t. 1; t. 2: Linia niesuchojeżska, cz. 1-2, oprac. Z.L. Radzimiński, Lwów 1911-1933, t. 3: Gałą́ koszyrska, oprac. B. Gorczak, Lwów 1906; biogramy Sanguszków w: PSB, t. 34, s. 462-524.

13 J. Rogulski, Nowożytny ród szlachecki, s. $502 \mathrm{n}$.

${ }_{14}$ M. Machynia, Sanguszko Wasyl, w: PSB, t. 34, s. 513-514.

15 Taką datę podaje Z.L. Radzimiński w niewydanym czwartym tomie Monografii XX. Sanguszków: BNANU-Lw., f. 91, k. 272. Pozostałe fakty biograficzne, o ile nie podano w przypisie inaczej, za: M. Nagielski, Sanguszko Samuel Szymon, s. 510-513. Autor biogramu podaje księcia pod imionami Samuel Szymon, jednak dokumenty, listy, a także sama genealogia (zob. aneks) nie pozostawiają wątpliwości, że sam zainteresowany posługiwał się imionami: Symeon Samuel. W taki też sposób nazywamy go w niniejszej pracy.

${ }^{16}$ Za metryką litewską J. Wolff, Kniaziowie, s. 453, podał, że Symeon Samuel Sanguszko otrzymał nominację na wojewodę witebskiego 21 V 1625. Podważył to M. Nagielski (tenże, Sanguszko Samuel Szymon, s. 511), który powołując się na list księcia z 1629 r., zasugerował, że urząd ten mógł zostać objęty przezeń nieco później. Cytowany list musi jednak zawierać błąd w dacie lub tytulaturze urzędniczej, gdyż w Archiwum Narodowym w Krakowie, Archiwum Sanguszków [dalej: ASang], odnajdujemy szereg listów i dokumentów z lat 1627-1628, które zawierają podpis: „Samuel Sanguszko z Kowla wojewoda witebski” (m.in.: tamże, rkps 86, k. 24; teka XXXVIII/4, s. 5; teka XXXXIX/51, s. 1).

17 W 1622 r. został mianowany komisarzem Rzeczypospolitej do rozmów z przedstawicielami Moskwy, a w 1623 r. został członkiem komisji śledczej do zbadania sprawy zamordowania w Witebsku arcybiskupa połockiego Jozafata Kuncewicza.

${ }_{18}$ Niektóre jego wiersze ukazały się drukiem; zob. zbiór wierszy z okazji ślubu Lwa Sapiehy i Elżbiety Radziwiłłowej: In nuptias Leonis Sapihae M. D. L. supremi cancellarii et Elisabethae Radiviliae ducis a Bierze et Dubinki..., Wilno 1599. Próbkę swoich umiejętności artystycznych książę Symeon Samuel dał na kartkach wszytych do francuskiego modlitewnika,
\end{abstract}


zgromadził pokaźny księgozbiór, na którego potrzeby przeznaczył osobne pomieszczenie biblioteczne ${ }^{19}$. Najcenniejszą i najsłynniejszą należącą do niego książką był zbiór modlitw maryjnych (godzinek) Horae Dive Virginis Marie secundum verum usum Romanum, wydany w Paryżu w oficynie Thelmana Kervera z datą 21 I $1505^{20}$. Ten kunsztowny, bogato zdobiony modlitewnik Symeon Samuel otrzymał od swojego przyjaciela, kasztelana połockiego Mikołaja Zenowicza, który poległ w bitwie chocimskiej we wrześniu $1621 \mathrm{r}^{21}$ Drogocenny nabytek nabrał wyjątkowej wartości dla księcia, osoby bardzo religijnej i w typowy dla neofity sposób mocno przywiązanej do wiary rzymskiej. To właśnie z tej „książęczki” postanowił uczynić swego rodzaju „relikwię” rodową i spisać w niej genealogię. Symeon Samuel kolekcjonował także drogocenne rękodzieła, które cieszyły się wielką sławą wśród jego współczesnych ${ }^{22}$.

Wśród nauk i zajęć, około których bawił się Symeon Samuel Sanguszko, czołowe miejsce zajmowały historia i genealogia. Książę interesował się dziejami litewskich rodów szlacheckich, a przede wszystkim dziejami własnej familii. Po raz pierwszy dał tego wyraz w 1620 r., kiedy to określił się mianem „Lubartowicza”, to jest potomka księcia Lubarta Giedyminowicza ${ }^{23}$. Następnie, ok. 1626 r., skomponował swój sześciopolowy herb złożony, w którym - jako drugi znak rodowy Sanguszków - pojawiły się Kolumny, rzekome „starożytne” godło Giedyminowiczów, uważanych wtedy za potomków rzymskiego rodu Kolumnów. W herbie tym pomieścił godła czterech potężnych familii litewskich, z którymi Sanguszkowie kowelscy byli blisko skoligaceni ${ }^{24}$. W latach 20. XVII w. Symeon Samuel wzniósł w Smolanach wspominaną rezydencję Biały Kowel, utrzymaną w stylu wczesnego baroku i w owym czasie bardzo efektowną ${ }^{25}$. Jej nazwa nawiązywała do dawnego gniazda rodzinnego Sanguszków kowelskich. Do wołyńskich korzeni odnosił się także przydomek „z Kowla”, którym Symeon Samuel regularnie posługiwał się w swoich listach i dokumentach ${ }^{26}$.

Jak więc widzimy, w spisaniu genealogii rodowej należy widzieć zwieńczenie studiów, jakie książę podjął nad dziejami własnego domu. Utwór ten powstał w tym samym czasie, w którym pojawiły się wyżej wymienione symbole nawiązujące do najdawniejszych dziejów familii, to jest w latach 20 . XVII w. Warto przy tym odnotować, że właśnie wtedy Symeon Samuel ukończył 40 lat. W świetle badań antropologicznych jest to wiek, kiedy pojawia się najsilniejsza potrzeba utrwalenia ważnych dla swojej wspólnoty wspomnień i przekazania ich potomstwu ${ }^{27}$. Symeon Samuel postanowił te wspomnienia przekazać w formie genealogii rodowej.

gdzie narysował św. Marię Magdalenę i św. Symeona. Kartki te musiały ulec zniszczeniu w trakcie I wojny światowej (por. dalej). Wcześniej widział je M. Sokołowski, Miniatury włoskie, s. 28-29, który stwierdził, że wykonane zostały „nie bez pewnego talentu".

${ }^{19}$ Księgozbiór Symeona Samuela Sanguszki omawia J.M. Marszalska, Biblioteka i archiwum Sanguszków, s. 79 n.

${ }^{20}$ Modlitewnik obecnie przechowywany w BN opatrzony sygn. XVI.O.2729. Opis druku w: Inventaire chronologique des éditions parisiennes du XVI siècle, wyd. B. Moreau z rkpsu Ph. Renouard, cz. 1: 1501-1510, Paryż 1972, nr 99, s. 161.

${ }^{21}$ Symeon Samuel Sanguszko opisał w modlitewniku okoliczności, w jakich ta książeczka znalazła się w jego rękach (por. dalej).

${ }^{22}$ Posiadał m.in. zegar, „na którego wierzchołku śmierć widzieć było, na niej zaś kolumna światowej nikczemności symbola reprezentowała, która za każdem godziny wybijaniem obracała się"; za: K. Niesiecki, Herbarz polski, t. 8, s. 238.

23 J. Wolff, Kniaziowie, s. 453; wg Z. Radzimińskiego patronimik pojawił się już w 1605 r. (BNANU-Lw, f. 91, spr. 210, k. 273), wymaga to jednak weryfikacji, gdyż jego regularna obecność jest odnotowana dopiero dla lat 20.-30. XVII w. Wtedy to pojawia się w dokumentach Symeona Samuela (m.in. AN, ASang, teka XLIV/38, s. 580; teka XXXIV/51, s. 1), w legendzie jego pieczęci z 1629 r. (m.in. tamże, teka XL/47, s. 290) oraz w licznych dedykacjach i utworach panegirycznych (J. Herdel, Złote godziny [...] k woli szczęśliwemu hymenowi [...] Symeona Samuela Lubartowicza Sanguszka, [Wilno 1627]; T. Dygoń, Przemiana koni poszosnych pod lektykę [...] Symeona Samuela Lubartowicza Sanguszka, [Wilno] 1639; A. Hączel Mokrski, Pogonia żałobna [...] Symeona Samuela Lubartowicza Sanguszka, Wilno 1639).

${ }^{24}$ Były to herby: Lis Sapiehów, Kościesza Chodkiewiczów, Gozdawa Paców oraz Hipocentaurus Hornostajów; zob. analizę treści herbu w: J. Rogulski, Treści propagandowe herbu złożonego księcia Szymona Samuela Sanguszki z 1626 roku, w: Insignia et splendor. Heraldyka w stużbie rodów szlacheckich i instytucji Kościoła, red. W. Drelicharz, Kraków 2011, s. 9-84.

${ }^{25}$ R. Nestorow, Smolany Sanguszków w świetle inwentarzy i nieznanych materiałów archiwalnych, w: Wokót Sanguszków. Dzieje - sztuka - kultura. Materiały I Ogólnopolskiej Konferencji Naukowej, 29-30 czerwiec 2006, Ratusz, Muzeum Okręgowe w Tarnowie, red. J. Skrabski, B. Bułdys, Tarnów 2007, s. 109-117.

${ }^{26}$ M.in. AN, ASang, teka XXXIX/48 s. 311; por. dalej.

27 J. Assmann, Pamięć kulturowa. Pismo, zapamiętywanie i polityczna tożsamość w cywilizacjach starożytnych, tłum. A. Kryczyńska-Pham, wstęp i red. R. Traba, wyd. 2, Warszawa 2015, s. 66. 


\section{Czas powstania zabytku}

O tym, kiedy Symeon Samuel Sanguszko zaczął pisać swoje dziełko dowiadujemy się z jego krótkiego wstępu, w którym przedstawił się jako kasztelan witebski (Aneks, s. 1/177) ${ }^{28}$. Jak wspomniano, książę piastował ten urząd w latach 1621-1626, w związku z tym nie ulega wątpliwości, że to wtedy zaczął pracować na tekstem. Już jednak pisząc o sobie w dalszej części utworu, podał inny tytuł urzędniczy: „wojewoda witebski, suraski starosta” (s. 6/183). Wynika stąd, że pisał genealogię w dwóch etapach, przy czym opracowanie drugiej części nastąpiło nieco później, już po otrzymaniu nominacji na urząd wojewody witebskiego (21 V 1626).

Datę rozpoczęcia opracowywania utworu możemy uściślić na postawie informacji, które Symeon Samuel wpisał do drogocennego modlitewnika francuskiego, gdzie, jak pamiętamy, postanowił zamieścić swoje dziełko. Ze wstępu do niego wynika jednoznacznie, że książę pracował na kartkach wszytych do godzinek ${ }^{29}$. Na podstawie kilku dopisków z modlitewnika można stwierdzić, że wszycie tych kartek, mających formę niewielkiego zeszyciku, nastąpiło w latach 1625-1626. W 1625 r. na karcie tytułowej cennego druku książę dodał sygnaturę oznajmiającą, kto jest właścicielem modlitewnika ${ }^{30}$, a niezawodnie przy tej samej okazji dorysował tam swój herb złożony ${ }^{31}$. Wydaje się pewne, że obie te czynności nastąpiły zaraz po tym, jak darowany Sanguszce modlitewnik dotarł do adresata. Spisanie genealogii (przynajmniej na tych kartkach) nie mogło więc nastąpić przed 1625 r. Z kolei rok później w omawianym zeszyciku Symeon Samuel narysował wizerunek św. Marii Magdaleny. Fakt ten wskazuje, że już wtedy kartki były dołączone do książeczki ${ }^{32}$. Obserwacje te pozwalają datować początek powstawania dziełka Symeona Samuela na lata 1625-1626.

Z kolei analiza informacji zawartych $\mathrm{w}$ treści genealogii pozwala doprecyzować, kiedy nastąpił drugi etap opracowywania tekstu. Najwcześniej mogło to nastąpić pod koniec 1629 r., gdyż z tego roku pochodzą najpóźniejsze fakty biograficzne odnotowane na jego kartach: nominacja Adama Aleksandra Sanguszki z linii koszyrskiej na województwo wołyńskie (4 VIII 1629) (s. 4/182) oraz śmierć Zofii, drugiej córki Symeona Samuela (1629; s. 6/183). Z kolei ukończenie pisania nie mogło nastąpić później niż w 1634 r., gdyż w tym roku owdowiała najstarsza córka księcia, Katarzyna Stetkiewiczowa, a fakt ten bez wątpienia zostałby odnotowany w genealogii. Ramy czasowe dokończenia dziełka można zawęzić do lat 1629-1634.

Genealogia rodu Sanguszków powstała zatem w dwóch etapach - w latach 1625-1626 i 1629-1634. Analiza pisma pozwala wskazać miejsce, gdzie Symeon Samuel skończył pisać pierwszą część utworu, by po kilku latach wrócić do jego dalszego opracowania. Początek genealogii pisany jest drobną i zdyscyplinowaną kursywą, równym wersami zapełniającą płaszczyznę pergaminowej karty, przy zachowaniu bocznego marginesu. Taki dukt utrzymuje się mniej więcej do połowy trzeciej strony genealogii, tj. biogramu księcia Romana Sanguszki. W tym miejscu pismo ulega zmianie: litery stają się większe, dukt nieco chaotyczny (choć wciąż staranny), wersy rozluźniają się, a zjawiska te przybierają na sile

${ }^{28}$ Numeracja stron wg oryginału wraz z podaniem strony w opublikowanym dalej Aneksie.

29 Autor apeluje do syna, aby nie zapomniał „tej książki, której antiquitas godna jest zachowania”, gdyż „origo i pożycie familii jest [tam] opisane"; zob. Aneks, s. 1/177.

30 „Sum possesor huius libri Symeon Samuel Sanguscius Dux de Kowel kasthe[lanus] witeb[ciensis]. Anno 1625 et editus est liber ab - a[nno] 1505 ad hunc annu[m] 120 annis"; napis ten jest obecnie częściowo zatarty, a jego pełne brzmienie za: M. Sokołowski, Miniatury włoskie, s. 24.

31 Jest to skromniejsza wersja późniejszej sześciopolowej kompozycji, zbudowana z Pogoni Sanguszków, Lisa Sapiehów, Kościeszy Chodkiewiczów i Gozdawy Paców. W tym samym czasie książę Symeon Samuel musiał także dodać na jednej z dalszych stron dopisek objaśniający okoliczności, w jakich wszedł w posiadanie książeczki: „Facta expeditione contra Turcas cum in conflictu in finibus Walachie a Turcis vulneribus multis de fatigatus obiit mag[nificus] dominus Nicolaus Boguslaus Zienovic castellanus polocensis a[nno] d[omini] 1621 iste libellus antiquitate clarus ad manus meas pervenit Symeonis Samueli Lubartovic Sanguscii ducis de Cowel cast[ellanus] witeb[censis]"; napis ten jest obecnie całkowicie zatarty, jego treść za: tamże, s. 28.

32 Według M. Sokołowskiego (tamże, s. 28), pod wizerunkiem św. Marii Magdaleny znajdował się wyraźny napis: „per me S. Sangusko delineata 1626". Niewątpliwie z tego samego czasu pochodzi także wizerunek patrona księcia, św. Symeona, gdyż oba te rysunki miały na celu uzupełnić zespół świętych ukazanych w modlitewniku. 
na kolejnych kartach utworu. Różnice te wydają się wynikać z faktu, że tekst był pisany w dwóch etapach, oddalonych od siebie o kilka lat. Co ciekawe, w miejscu tym następuje także zmiana dominującego źródła informacji, z którego korzystał autor: pierwsza część tekstu oparta jest na przekazie kronik, druga zaś na wiadomościach utrwalonych w pamięci rodowej Sanguszków (por. dalej).

Na podstawie powyższych obserwacji można stwierdzić, że Symeon Samuel zaczął spisywać dziełko w latach 1625-1626, dysponując wyłącznie przekazem dzieł historiograficznych. Dopiero po spisaniu tej części zaczął gromadzić materiały do dalszych dziejów familii, co polegało na pozyskiwaniu wiadomości od krewnych bądź odnajdywaniu nośników ważnych informacji gromadzonymi przez ród. Z tego też powodu druga część genealogii powstała dopiero po kilku latach, to jest pomiędzy 1629 a 1634 r. Pomimo znacznego odstępu czasu Symeonowi Samuelowi nie udało się uzyskać wszystkich potrzebnych mu informacji. Świadczy o tym wiele pustych miejsc pozostawionych przez niego w drugiej części utworu (por. dalej). Długotrwały proces spisywania dzieła oraz niekompletność wiadomości dowodzi, że dla XVII-wiecznego magnata sporządzenie genealogii obejmującej całość dziejów własnej familii było nie lada wyzwaniem, wymagającym wieloletnich badań i pokonania wielu trudności.

\section{Rękopisy}

Jak wiadomo, losy najstarszego rękopisu dziełka były od początku związane z drogocennym zbiorem godzinek Horae Dive Virginis Marie secundum verum usum Romanum z 1505 r. (il. 1). Jest to niewielki, kunsztowny druk in $8^{\mathrm{vo}}$, na gładkim i cienkim pergaminie, z licznymi rycinami i ornamentami, oprawiony w skórę, ze skuwkami. Na samym końcu tej książeczki Symeon Samuel doprawił niewielki, ośmiokartkowy zeszycik, o wymiarach ok. 16,5 x $10,5 \mathrm{~cm}$, również in $8^{\mathrm{vo}}$, wykonany jednak z grubszego i gorszej jakości pergaminu (il. 2). W tym to zeszyciku, na ostatnich czterech kartach, była spisana genealogia. Karty te zachowały się szczęśliwie do naszych czasów i są obecnie przechowane w zasobie AGAD, w szóstym tomie kolekcji Michała Marczaka ${ }^{33}$.

Po śmierci Symeona Samuela Sanguszki cenna książeczka pozostawała w Białym Kowlu, tam też tekst genealogii został dwukrotnie uzupełniony innymi rękoma. Pierwszy dopisek pochodzi z $1661 \mathrm{r}$. i został dokonany przez Katarzynę Sanguszkównę, wnuczkę Symeona Samuela ${ }^{34}$. Jest on poświęcony rodzicom księżnej, wujom oraz bratu. Drugi wpis powstał po 1692 r. ${ }^{35}$ Niestety ręki, którego go dokonała, nie sposób jednoznacznie zidentyfikować, gdyż ten fragment rękopisu jest obecnie nieczytelny. Biorąc jednak pod uwagę treść i formę dopisku (znane z późniejszych kopii), należy przypuszczać, że jego autorem była prawnuczka autora, Anna Sanguszkówna (1676-1746) ${ }^{36}$. Księżna ta nie tylko wiedziała o modlitewniku i obecnej w niej genealogii, ale także wielce sobie ceniła tę książeczkę, skoro włączyła je do swojej kolekcji bibliotecznej i po ślubie z Karolem Stanisławem Radziwiłłem w 1692 r. zabrała do swojej nowej rezydencji. O nowym miejscu przechowywania dowiadujemy się z listu Józefa Andrzeja Załuskiego z 1731 r., w którym słynny bibliofil chwali się, że posiada genealogię

33 AGAD, Zespół Michała Marczaka, s. 7-14. Rękopis ten zostanie dokładnie opisany w rozdziale poświęconym podstawie i zasadom edycji.

${ }^{34}$ Ręka, która dokonała tego wpisu, podaję datę jego sporządzenia (Aneks, s. 6/184). Ponieważ księżną Annę Radziwiłłównę, żonę Jana Władysława Sanguszki, określa mianem „księżnej matki”, autorem musiało być któreś z dwójki ich dzieci, Hieronim i Katarzyna. Wpisu tego mogła dokonać tylko ta ostatnia, gdyż syn Hieronim miał w 1661 r. zaledwie 12 lat, o czym zresztą wspomina sama autorka wpisu.

35 Dopisek odnotowuje datę zawarcia małżeństwa pomiędzy Anną Sanguszkówną a Karolem Stanisławem Radziwiłłem (1692), musiał więc powstać po tej dacie. Z drugiej zaś strony nie wspomina o małżeństwie Krystyny Sanguszkówny z księciem Władysławem Jozafatem Sapiehą (1697), co zamyka ramy chronologiczne powstania wpisu.

${ }^{36}$ Wpis zawiera informację o małżeństwie księcia Hieronima Sanguszki z Konstancją Sapieżanką oraz wykaz ich dzieci. Para ta miała czwórkę dzieci, Kazimierza Antoniego, Annę, Pawła Karola i Krystynę, przy czym ostatnia dwójka była na początku lat 90. XVII w. zbyt młoda, aby dokonać tego wpisu, zatem jego autorem mógł być Kazimierz Antoni lub Anna, a ze względu na fakt, że księżna ta była potem w posiadaniu modlitewnika, ostatnią możliwość należy uznać za bardziej prawdopodobną. Więcej o księżnej Annie z Sanguszków Radziwiłłowej zob. W. Karkucińska, Anna z Sanguszków Radziwiłłowa (1676-1746). Działalność gospodarcza i mecenat, Warszawa 2000. 


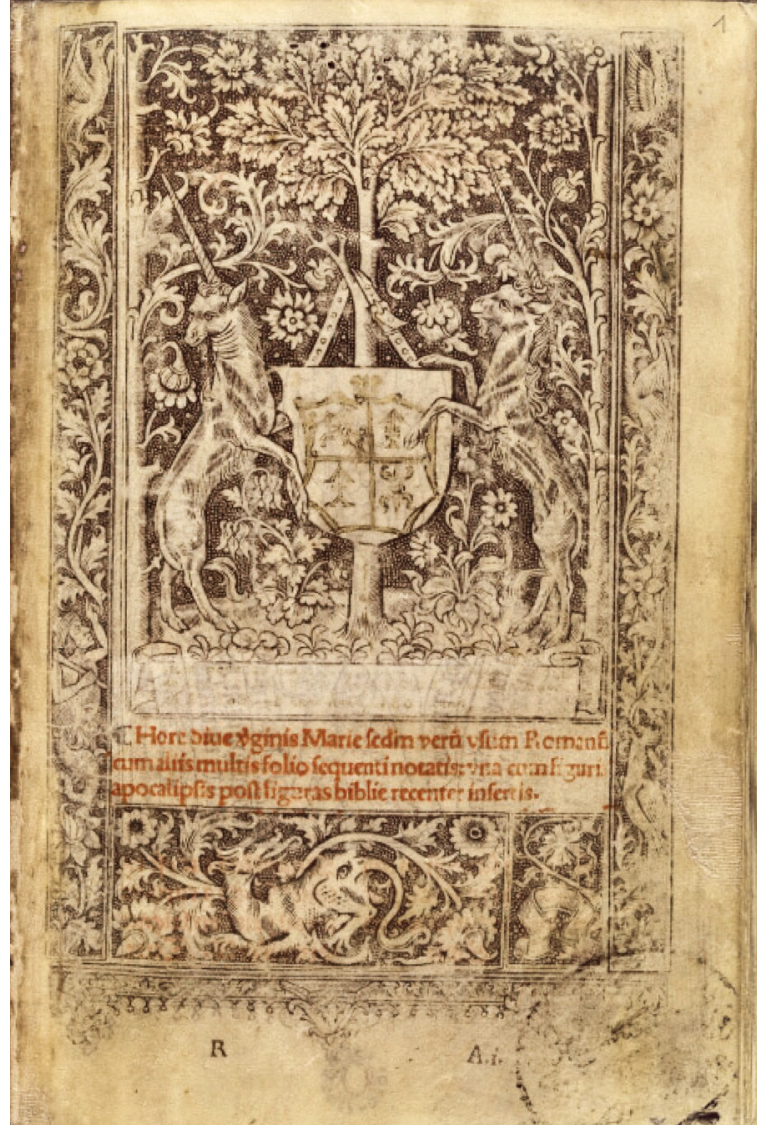

I1. 1. Karta tytułowa francuskiego modlitewnika Horae Dive Virginis Mariae secundum verum usum Romanum z 1505 r. W polu tarczy trzymanej przez jednorożce herb złożony Symeona Samuela Sanguszki, narysowany przez właściciela; BN, sygn. XVI.O.2729, k. 1r (Polona.pl)

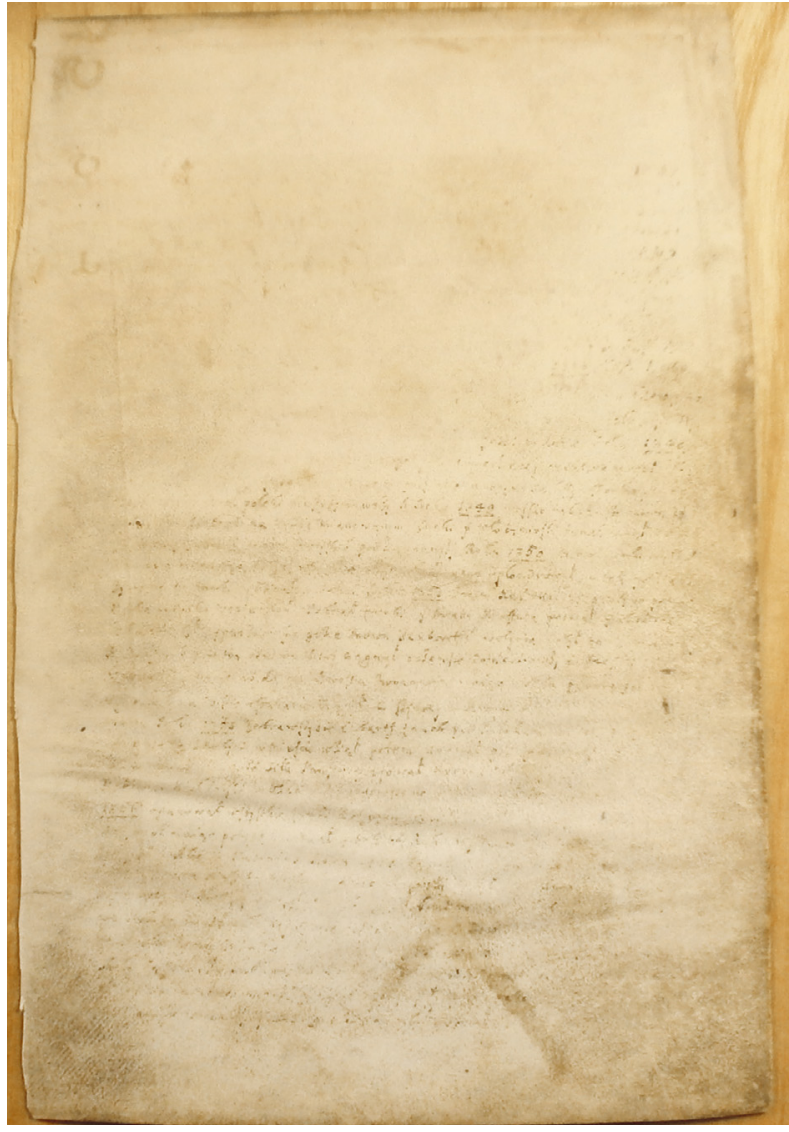

Il. 2. Pierwsza strona rękopisu Symeona Samuela Sanguszki z lat 1625-1634; AGAD, Zespół Michała Marczaka, t. 6, s. 7

Sanguszków „exactissime zrobioną”, a wziętą „,ex manuscripto samego książęcia Sanguszki, wojewody wołyńskiego [sic!], mając go sobie propria eius manus komunikowany in originali, od księżnej Jejmości kanclerzynej litewskiej sub tempus prosperitatis"37. Ze względu na obecność rękopisu Symeona Samuela książeczka musiała znajdować się w skarbcu księżnej jako część zgromadzonej przez nią kolekcji genealogii rodowych ${ }^{38}$.

$\mathrm{W}$ ten oto sposób cenny modlitewnik z najstarszym rękopisem genealogii rodowej opuścił dom Sanguszków i trafił w ręce Radziwiłłów. Od $1731 \mathrm{r}$. ślad po cennym starodruku urywa się na przeszło sto lat. Niewątpliwie książeczka wraz z całą kolekcją Anny Radziwiłłówny została ok. 1750 r. prze-

${ }^{37}$ Korespondencja Józefa Andrzeja Załuskiego 1724-1736, oprac. B.S. Kupść, K. Muszyńska, Wrocław-Warszawa-Kraków 1967, nr 108, list do Jana Fryderyka Sapiehy, 10 VI 1731, s. 62-63.

38 Zastanawiające jednak, że inwentarze księgozbioru Anny z Białej nie odnotowują cennych francuskich godzinek: przejrzano trzy katalogi podręcznego księgozbioru Anny Radziwiłłówny opublikowane jako aneks do: W. Karkucińska, Anna z Sanguszków Radziwiłłowa, s. 174-285. Księżna posiadała także drugi księgozbiór, określany mianem „biblioteki łacińskiej”, która miała inny profil niż biblioteka podręczna, lecz z analizy W. Karkucińskiej wynika, że modlitewnik nie znajdował się w tym zbiorze; tamże, s. 95-104. Wiadomo natomiast, że księżna Anna miała kolekcję genealogii obejmującą kilkadziesiąt zabytków tego rodzaju: w inwentarzu skarbca księżnej z 5 I 1733 znajdują się następujące pozycje: „enelogie papierowe”, „enelogy familijej Radziwił 34”, „,enelogy familijej Radziwił jedna stara 1”; cyt. za: W. Karkucińska, Anna z Sanguszków Radziwiłlowa, s. 103. 
wieziona z Białej do Nieświeża ${ }^{39}$. Tam, wraz z innymi genealogiami księżnej, musiała wejść do zasobu archiwum, gdyż w 1772 r. nieświeską bibliotekę wywieziono z Polski do Petersburga, a modlitewnik miał za kilkadziesiąt lat odnaleźć się w Dzikowie. W 1875 r. Franciszek Radziszewski wspominał, że „wiele rzeczy z archiwum [w Nieświeżu - J.R.] rozeszło się w różne ręce”"40. Taki los spotkał zapewne interesujący nas modlitewnik, skoro z artykułu opublikowanego 31 VIII 1852 w krakowskim „Czasie” dowiadujemy się, że „wielce ciekawa książeczka do modlenia łacińska”, z „dopiskami ręką księcia Simeona Janusza [sic!] Sanguszki” i ,spisaną przez niego własnoręcznie genealogią Sanguszków”, znajduje się w zamku w Dzikowie ${ }^{41}$. Okoliczności, w jakich modlitewnik trafił w ręce hrabiów Tarnowskich, wydają się oczywiste: musiało to być zasługą sławnego „książkołapa” Tadeusza Czackiego, krewnego Jana Feliksa Tarnowskiego ${ }^{42}$. Tym samym cenny druk trafił do rodziny Tarnowskich w pierwszej połowie XIX w. To właśnie wtedy książę Władysław Hieronim Sanguszko, niewątpliwie pod wpływem świeżej informacji o „odkryciu” modlitewnika i obecnej tam genealogii rodu, zaoferował za ten „,enny dla jego rodziny zabytek" pięknego konia ${ }^{43}$.

Modlitewnik z genealogią pozostał w Dzikowie aż do I wojny światowej ${ }^{44}$. Według J. Grali, na początku wojny książeczka wraz z innymi najcenniejszymi eksponatami zostały ukryte $\mathrm{w}$ ziemi ${ }^{45}$. Po odkopaniu okazało się, iż znajdująca się w modlitewniku genealogia jest w tak złym stanie, że dzikowski bibliotekarz i archiwista Michał Marczak postanowił wyciąć zeszycik pergaminowy, aby zapobiec jego całkowitej deformacji. Po wysuszeniu włączył zabytek do swojej bogatej kolekcji archiwalnej, którą w $1951 \mathrm{r}$. wdowa po nim sprzedała $\mathrm{AGAD}^{46}$. Natomiast francuskie godzinki pozostały w Dzikowie do 1949 r., kiedy to wraz z ocalałą częścią kolekcji starodruków trafiły do zasobu Biblioteki Narodowej w Warszawie.

Wszyty do modlitewnika rękopis autorstwa księcia Symeona Samuela Sanguszki nie był jedynym nośnikiem treści interesującej nas genealogii. Zapotrzebowanie na dziełko było na tyle duże, że oryginał szybko posłużył za podstawę nowych odpisów oraz wyciągów w postaci tablic genealogicznych. Dla niniejszej edycji pierwszorzędne znaczenie mają zawierające cały tekst kopie utworu. Dysponujemy informacjami o czterech tego typu zabytkach, przy czym dwa z nich zachowały się do naszych czasów.

Najstarszą znaną kopią genealogii jest rękopis księcia Hieronima Władysława Sanguszki sporządzony ok. 1640 r. Hieronim Władysław (1611-1657) był drugim synem Symeona Samuela i wybrał karierę duchowną ${ }^{47}$. O istnieniu rękopisu dowiadujemy się dzięki Kasprowi Niesieckiemu, który opracowując herbarz Korona polska, korzystał z „genealogii domu tego książęcego od Hieronima księżęcia Sanguszka biskupa smoleńskiego zebraną koło roku 1640"48. Informacje, które przytacza dalej Niesiecki (por. dalej), nie pozostawiają wątpliwości, że była to kopia in extenso genealogii Symeona Samuela. Niestety rękopisu tego nie udało się odnaleźć.

O kolejnej kopii dziełka dysponujemy jeszcze mniejszą liczbą informacji. Fakt jej istnienia został ustalony na podstawie analizy dwóch XVIII-wiecznych rękopisów genealogii, które znajdują się w Archi-

39 F. Radziszewski, Wiadomości historyczno-statystyczne o znakomitych bibliotekach i archiwach publicznych i prywatnych tak niegdyś bytych jako i obecnie istniejacych, Kraków 1875, s. 52.

40 Tamże.

${ }^{41}$ Zapiski z wycieczek po kraju, „Czas”, 31 VII 1852, s. 1.

42 Inwentarze księgozbioru dzikowskiego nie odnotowują modlitewnika. Sprawdzono następujące katalogi biblioteki w Dzikowie: AN, Archiwum Dzikowskie Tarnowskich, sygn. 284, Alfabetyczny katalog biblioteki dzikowskiej, 1801-1842; tamże, sygn. 286, Katalog książek biblioteki dzikowskiej w językach obcych, 1801-1842; tamże, sygn. 313, Spis biblioteki w sali Perseusza, 1833 r.; tamże, sygn. 334, Katalog nowszych dzieł w bibliotece dzikowskiej, 1820-1850.

43 Odnotował to autor Zapisek z wycieczek po kraju: „Powiadano mi, że książę Sanguszko z Tarnowa ofiarował już za ten drogi dla jego rodziny zabytek pięknego konia”; „Czas”, 31 VII 1852, s. 1.

${ }_{44}$ AN, ASang, rkps 558, s. 55: karteczka z 1890 r. zachowana przy transkrypcji rękopisu Symeona Samuela Sanguszki (por. dalej) świadczy, że był on wtedy własnością Jana Tarnowskiego. Dwa lata później modlitewnik miał w rękach Marian Sokołowski, który przebywając w Dzikowie, opisał druk oraz rękopis w pracy: Miniatury włoskie, s. $23 \mathrm{n}$.

45 J. Grala, Kolekcja Michała Marczaka, s. 230.

46 Tamże, s. 223.

47 B. Kumor, Sanguszko Hieronim Władysław, w: PSB, t. 34, s. 482-484: Hieronim Władysław Sanguszko był jezuitą, święcenia kapłańskie otrzymał w 1636 r., w 1644 r. został sufraganem wileńskim, a w 1655 r. wstąpił na biskupstwo smoleńskie.

${ }^{48}$ K. Niesiecki, Herbarz polski, t. 8, s. 234. 
wum Narodowym w Krakowie (por. dalej). Obydwa rękopisy zawierają pomyłki na tyle specyficzne, że nie mogły one zostać skopiowane z oryginału, ale z jakiegoś późniejszego manuskryptu. Świadczy o tym poniższe zestawienie fragmentów oryginału z błędami obecnymi w obu XVIII-wiecznych rękopisach:

\begin{tabular}{|l|l|l|}
\hline \begin{tabular}{|l|l|} 
Rkps Symeona Samuela Sanguszki, \\
$\mathbf{1 6 2 5}-\mathbf{1 6 3 4}$
\end{tabular} & \multicolumn{1}{|c|}{$\begin{array}{c}\text { Rkps N.N. (Pawła Karola } \\
\text { Sanguszki?), 1709/1711 }\end{array}$} & Rkps Krystyny Sanguszkówny, 1743 \\
\hline Witenes z Ejrgoły & Witenes Feragolii & Witenes Feragulii \\
\hline $\begin{array}{l}\text { przybył za króla polskiego Władysława } \\
\text { Łokietka }\end{array}$ & ab argentia ab argena książę pestańskie & ab argena książę pestańskie \\
\hline Za żonę dał mu & Awżan [sic!] dał mu & Aużan [sic!] dał mu \\
\hline
\end{tabular}

Na ich podstawie można jednak wysnuć kilka istotnych wniosków dotyczących owego nieznanego źródła. Po pierwsze, zostało ono sporządzone pomiędzy 1692 a 1709/1711 r. ${ }^{49}$, po drugie zaś znajdowało się w Białej u wspomnianej wyżej księżnej Anny Radziwiłłówny. Należy więc przypuszczać, że interesujący nas nieznany manuskrypt powstał z inicjatywy księżnej, która była wówczas posiadaczką modlitewnika z oryginałem genealogii. Fakt ten ewidentnie wskazuje na okoliczności, w jakich zdecydowano o stworzeniu owej kopii. Już wtedy musiały się pojawić problemy z korzystaniem z rękopisu Symeona Samuela, który spisany drobnym duktem na niewielkich kartach był trudno czytelny ${ }^{50}$.

Kolejne znane rękopisy to wspomniane XVIII-wieczne kopie, które znajdują się w zasobie AN jako część archiwum rodowego Sanguszków. Pierwszy z rękopisów powstał na sześciu kartkach papieru niewielkiego rozmiaru $(165 \times 105 \mathrm{~mm})$, zszytych w formę 12-stronicowego zeszytu, bez oprawy (il. 3) $)^{51}$. Został on spisany nieznaną ręką pomiędzy 1709 a $1711 \mathrm{r}^{52}$ Rękopis nie zawiera niestety żadnych informacji na temat swojego przeznaczenia. Biorąc jednak pod uwagę, że przetrwał w archiwum domu Sanguszków, można zakładać, że - podobnie jak pozostałe znane pełnotekstowe kopie genealogii - powstał on na użytek któregoś z przedstawicieli rodu. W tym czasie mógł to być wyłącznie książę Paweł Karol Sanguszko (1680-1750). Taka atrybucja jest tym bardziej prawdopodobna, że jak wspomniano - modlitewnik z oryginałem genealogii znajdował się wtedy w Białej, u jego starszej siostry Anny Radziwiłłówny. Należy uznać za pewne, że Paweł Karol, jako głowa rodu Sanguszków, wystarał się o własną kopię dziełka, która pozostawała do użytku jego i jego potomstwa. Tą właśnie kopią wydaje się ta zachowana $\mathrm{w}$ archiwum rodowym. Omawiany zabytek został raz uzupełniony, pomiędzy 1768 a 1771 r. Wprowadzone wtedy nieznaną rękę informacje dotyczyły właśnie księcia Pawła Karola, jego kolejnych małżonek oraz potomstwa. To także potwierdza sugerowaną wyżej atrybucję rękopisu.

Ostatnia ze znanych kopii genealogii Sanguszków została sporządzona w 1743 r., w Białej, dla młodszej siostry Pawła Karola, księżnej Krystyny Sanguszkówny (zm. 1756), w latach 1697-1733 żony Władysława Jozafata Sapiehy (il. 4) ${ }^{53}$. Jako jedyna nosi ona tytuł: „Dom Jaśnie Oświeconych Książąt Sanguszków...”, a o jej przeznaczaniu dla księżnej Krystyny informuje wprost autor kopii, niejaki Jakubowski ${ }^{54}$. Rękopis ten został sporządzony w malutkiej papierowej książeczce $(92 \times 60 \mathrm{~mm})$ in $16^{\circ}$, o tekturowej oprawie, mieszcząc się na 28 stronach. Był on uzupełniany dwukrotnie w Lubartowie, niewątpliwie ręką samej właścicielki rękopisu, księżnej Krystyny, która po śmierci męża zamieszkała

49 W latach 1709-1711 powstała pierwsza z kopii nieznanego manuskryptu (por. dalej).

${ }^{50}$ Dotychczasowa kwerenda w AGAD, Archiwum Warszawskie Radziwiłłów nie przyniosła pozytywnego rezultatu i omawiany rękopis pozostaje nieodnaleziony.

${ }^{51}$ AN, ASang, rkps 558, s. 33-42.

${ }^{52}$ Rękopis odnotowuje z jednej strony fakt, że Władysław Jozafat Sapieha sprawuje urząd wojewody brzeskiego (1709), a z drugiej nie uwzględnia objęcia przez Pawła Karola Sanguszkę urzędu podskarbiego nadwornego litewskiego (1711).

${ }_{53}$ AN, ASang, rkps 558, s. 1-32.

54 Strona tytułowa kopii: „Dom Jaśnie Oświeconych Książąt Sanguszków, [...] z której teraz wypisawszy dla Jaśnie Oświeconej Księżnej Jej Mość Dobrodziejki z Sanguszków Krystynie Sapieżynej, wojewodzinie brzeskiej, tą książęczką ofiaruję się. Scripsit Jakubowski"; tamże, s. 3. 


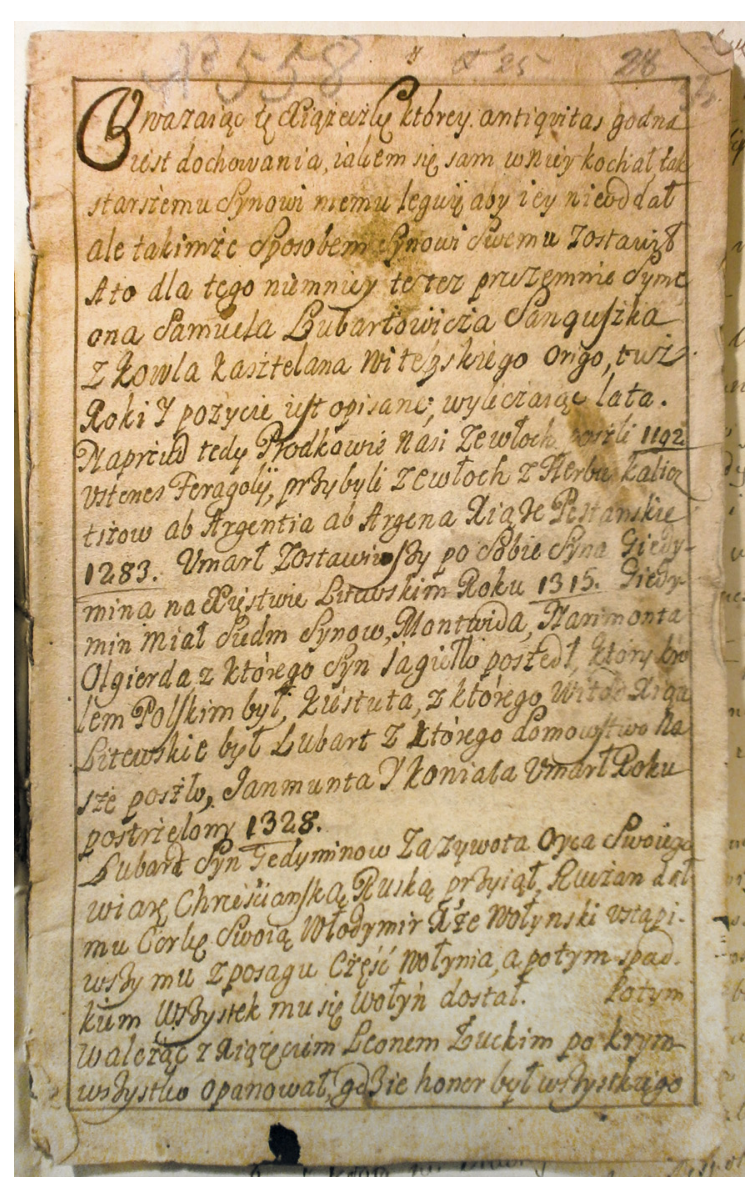

Il. 3. Pierwsza strona rękopisu N.N. (Pawła Karola Sanguszki?) z 1709/1711 r.; AN, Archiwum Sanguszków, rkps 558, s. 33

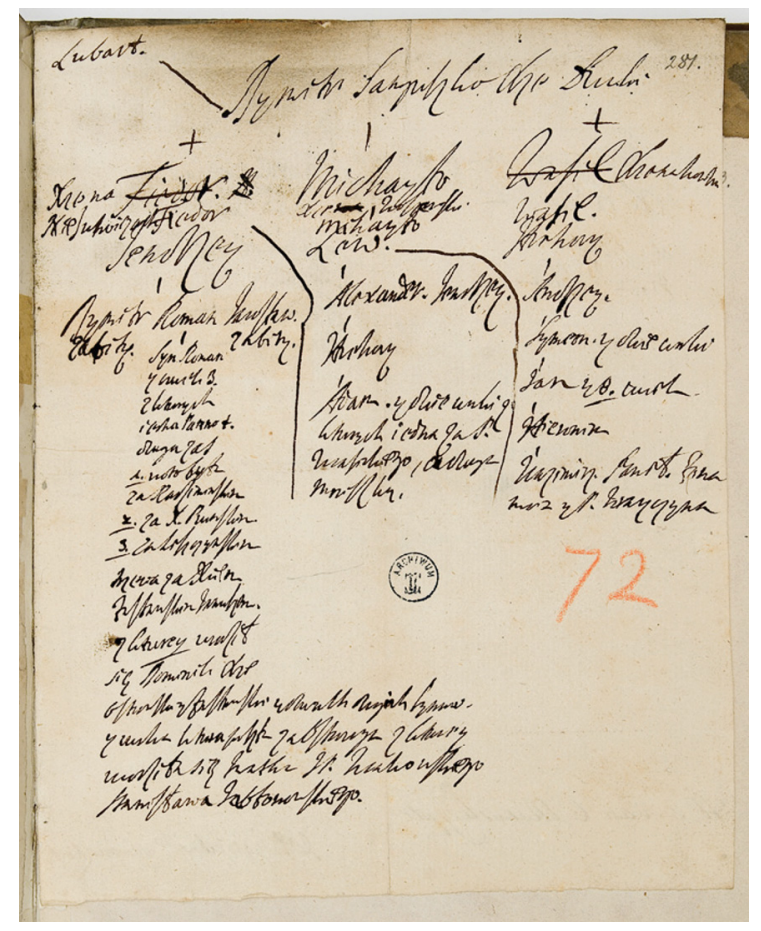

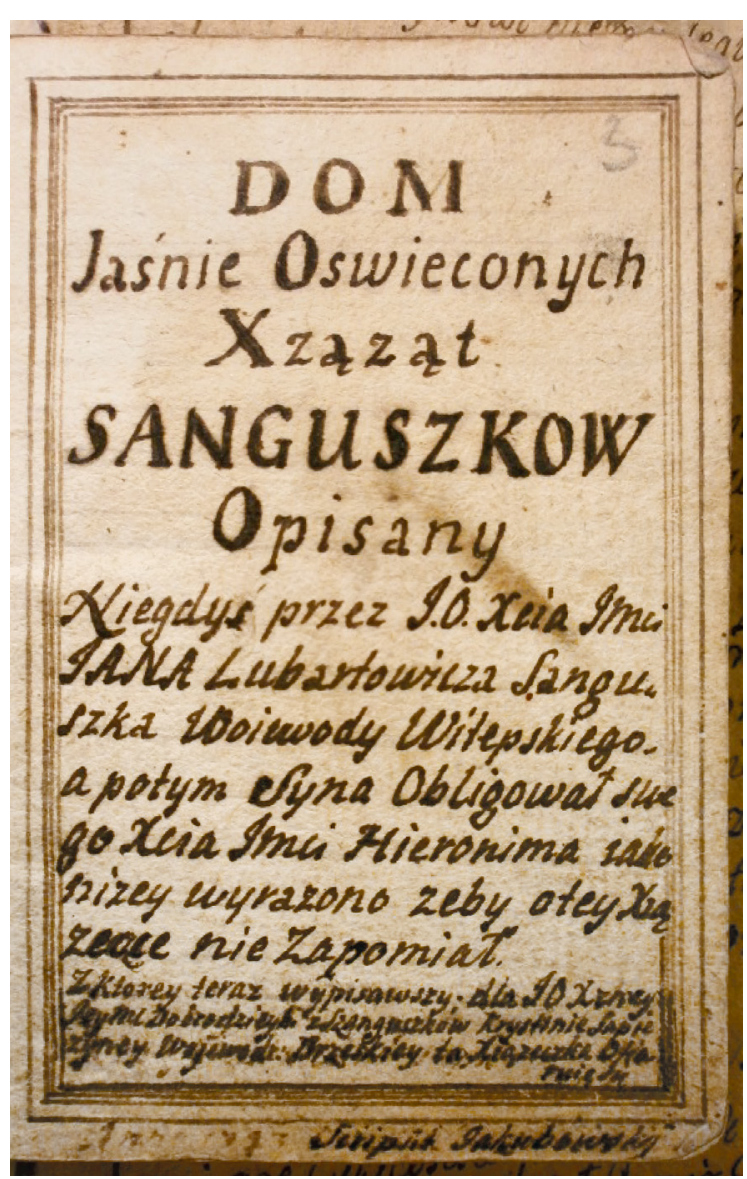

Il. 4. Pierwsza strona rękopisu księżnej Krystyny Sanguszkówny z 1743 r.; AN, Archiwum Sanguszków, rkps 558, s. 1
Il. 5. Tablica genealogiczna sporządzona na podstawie genealogii Sanguszków autorstwa Symeona Samuela Sanguszki, początek XVIII w.; BCzart., rkps 223, s. 281 
w rezydencji swojego brata. W 1749 i 1750 r. odnotowała ona w swojej genealogii fakty z życia swojego brata Pawła Karola, jego małżonek oraz dzieci.

Z powyższych ustaleń wynika, że obecnie znane pełnotekstowe kopie genealogii powstawały w XVII i XVIII w. na użytek przedstawicieli rodu Sanguszków, którzy nie mając na co dzień dostępu do modlitewnika francuskiego, pragnęli posiadać własny egzemplarz genealogii domowej (rys. 2). Jak jednak wspomniano, dziełko to funkcjonowało także w postaci wyciągów mających postać tablic genealogicznych. Jak się wydaje, takie zabytki powstawały zasadniczo na zlecenie innych rodów, jako uzupełnienie gromadzonych przez nich kolekcji genealogii rodowych. Taka tablica, wykonana na luźnej kartce papieru, zachowała się w Bibliotece Książąt Czartoryskich w Krakowie (il. 5) ${ }^{55}$. Pochodzi ona z początku XVIII w. i była bez wątpienia użytkowana przez Czartoryskich. Analiza treści pozwala jedynie domniemywać, że tablica powstawała na podstawie nieznanego rękopisu z Białej lub manuskryptu przypisywanego Pawłowi Karolowi Sanguszce ${ }^{56}$. Być może taką też postać miała także genealogia, którą chwalił się Józef Andrzej Załuski w cytowanym wyżej liście z 1731 r.

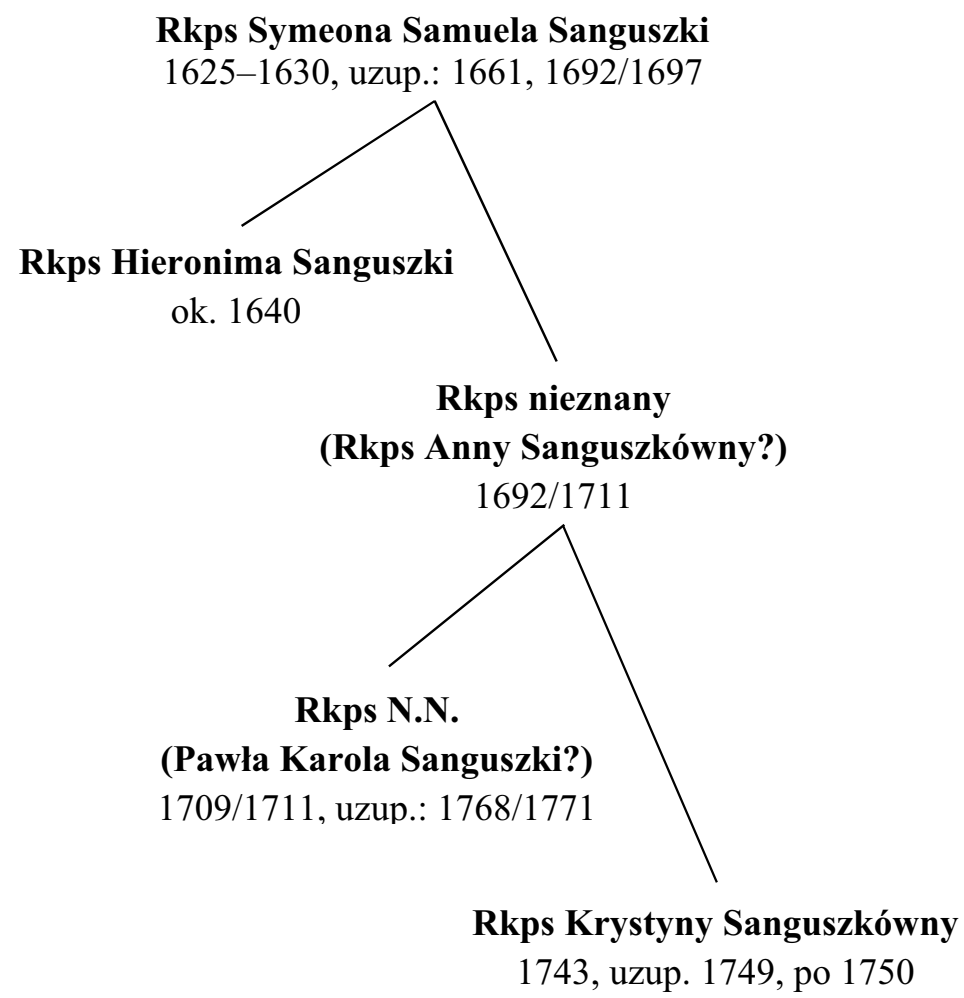

Rys. 1. Filiacja ustalonych rękopisów genealogii rodu Sanguszków autorstwa księcia Symeona Samuela Sanguszki z XVII-XVIII w.

\section{Źródła informacji}

Genealogia Symeona Samuela jest niewielkim utworem dziejopisarskim, który ukazuje dzieje rodu Sanguszków w porządku genealogicznym: poczynając od protoplasty, prezentuje biogramy (lub fakty biograficzne) przedstawicieli kolejnych generacji familii, porządkując ich według poszczególnych gałęzi rodowych. Analiza takiego zabytku wymaga w pierwszym rzędzie postawienia pytania o źródła

${ }_{55}$ BCzart., rkps 223, s. 281-282.

${ }^{56}$ Podstawą tych przypuszczeń jest fakt, że ostatnim przedstawicielem Sanguszków odnotowanym w tej tablicy jest książę Kazimierz Antoni Sanguszko, zmarły w 1706 r. 
podawanych w nim informacji. To podstawowa kwestia dla rozpoznania kultury historycznej, której owocem było powstanie tego tekstu. Analiza źródeł i sposobu korzystania z nich pozwala określić metody, jakie autor genealogii stosował przy odtwarzaniu dziejów swojego rodu, czyli poznać jego warsztat historyczny, a także określić zasięg i rodzaj wspomnień utrwalających się w pamięci reprezentowanej przezeń wspólnoty, co oznacza rozpoznanie kultury pamięci rodu Sanguszków.

\section{Piśmiennictwo historyczne}

$\mathrm{Na}$ pierwszej stronie swojej genealogii, relacjonując walki protoplasty rodu, księcia Lubarta Giedyminowicza, z królem Kazimierzem Wielkim, Symeon Samuel Sanguszko kładzie znamienną uwagę: „co szyrzej w kronice”. Odnośnik ten jasno wskazuje, że książę korzystał z jakiegoś zabytku piśmiennictwa historycznego, nigdzie jednak nie opisuje go dokładniej. Dopiero drobiazgowe porównanie treści genealogii z XVI-wiecznymi kronikami polskimi i litewskimi pozwala ustalić, że korzystał on z Kroniki polskiej, litewskiej, żmódzkiej i wszystkiej Rusi autorstwa Macieja Stryjkowskiego, wydanej w Królewcu w 1582 r. $^{57}$

Poniższe zestawienie dwóch fragmentów genealogii z odpowiadającymi im ustępami z kroniki Stryjkowskiego ukazuje nie tylko zbieżność zawartych treści, ale także ewidentne podobieństwo sformułowań obecnych w obu utworach. Potwierdza to, że Symeon Samuel Sanguszko czerpał informacje ze wspomnianego wyżej dzieła:

Genealogia, s. 1:

Za żonę dał mu [Lubartowi - J.R.] córkę swoją Włodzimierz książę wołyńskie, ustąpiwszy mu w posagu części Wołynia, a potem spadkiem wszystek mu się Wołyń dostał. Potem, walcząc z książęciem Leonem łuckim, po którym wszystko opanował, gdzie panem był wszystkiego Wołynia, i wiele ruskich książąt podbiwszy wojną, aż do węgierskich gór panowat.
Kronika, t. 2, s. 21

Lubart zaś, iż był pojął w małżeński stan córkę u Włodimirza kniazia wołodimirskiego i wołyńskiego wziął był po niej w posagu część udzieloną na Wołyniu, a [...] potym Giedymin [...] wziął wszystko księstwo włodimirskie i wołyńskie [...] i dał je Lubartowi synowi, który też miał tych księstw dziedziczkę za małżonkę, [...] a potym i łuckie księstwo, gdy był także [...] Lew kniaź łucki od Litwy zabity, Lubartowi spadkiem przyszło, a tak na ruskich księstwach [...] aż do Lwowa i węgierskich gór [...] państwo swoje spadkami i wojną w ruskich księstwach był rozciągnął.

Genealogia, s. 1:

Potem, za nastąpieniem króla Kazimierza polskiego, który zebrawszy wojsko niemałe, dobywał Lwowa pod Lubartem i wziął go przez podanie roku 1340, gdzie wszystkie państwa jego opanował, a z ugody, choć przez niechęć, niektóre wrócił, obowiązując się sobie przez to każdego nieprzyjaciela, o czem są listy w skarbie i teraz.

\section{Kronika, t. 2, s. 20:}

Kazimierz, król polski, roku 1340 [...] naprzód Lwów obległ i [...] wziął miasto z obiema zamkami przez podanie. [...] Potym zaś Kazimierz [...] z wojskiem dla podbicia ostatka Rusi [...] ciągnął [...] i wszytkie onych wołości zamki pobrał, i tak aż do Krzemieńca $\mathrm{z}$ wojskiem bez odporu przyszedt, o który jednak z umowy z [...] książęty litewskimi [...] zgodził się, iż Jurgi Narymuntowic miał [...] na Krzemieńcu panować, [...] a włodimirskie, łuckie, bełskie, chełmińskie, brzeskie państwa [...]

\footnotetext{
${ }^{57}$ M. Stryjkowski, Która przedtym nigdy świata nie widziała kronika polska, litewska, żmódzka i wszystkiej Rusi kijowskiej, moskiewskiej, siewierskiej, wotyńskiej, podolskiej, podgorskiej, podlaskiej etc., Królewiec 1582 (nowe wyd.: Kronika polska, litewska, żmódzka i wszystkiej Rusi Macieja Stryjkowskiego, t. 1-2, Warszawa 1846).
} 
przy litewskich książętach zostawił [...] potym Kiejstut i Olgierd to postanowienie [...] odnowili i jest zapis ich teraz w skarbie królewskim na zamku krakowskim.

Jak widać, książę Symeon Samuel streszczał całe ustępy kroniki Stryjkowskiego. W ten sposób powstało ok. 40\% jego genealogii: cały początek utworu, czyli opis czynów Lubarta Giedyminowicza, a także znaczna część biogramu księcia Romana Sanguszki, sławnego hetmana litewskiego, pogromcy Moskali. Ponadto z kroniki litewskiego dziejopisa książę zaczerpnął niemal wszystkie daty: tylko w dwóch przypadkach daty z genealogii nie znajdują potwierdzenia w kronice. Dzięki temu, że ta część genealogii stanowi wyciąg ze Stryjkowskiego, odznacza się ona pewnym poziomem literackim.

Z dzieła litewskiego dziejopisa Symeon Samuel korzystał bezkrytycznie, wiernie przepisując daty i fakty dotyczące interesujących go osób. W kilku miejscach występują co prawda odstępstwa od przekazu kroniki, są to jednak niewątpliwie pomyłki, wskazujące, że autor mógł opierać się na wcześniej sporządzonych notatkach ${ }^{58}$. Było to typowe dla myślenia historycznego tamtych czasów: wzmianka odnaleziona $\mathrm{w}$ wielkim dziele kronikarskim uchodziła de facto za niepodważalny pewnik (można ją było zakwestionować, tylko weryfikując z innym tego typu dziełem). Dlatego też mówiąc o warsztacie historycznym księcia Symeona Samuela, należy zwrócić uwagę na inną kwestię. Po pierwsze, był on w stanie zlokalizować w ówczesnym piśmiennictwie historycznym taką kronikę, w której informacji o jego rodzie było najwięcej, a po drugie - potrafił skrupulatnie odnaleźć wszystkie wzmianki i dokonać ich kompilacji. Wnikliwa analiza treści genealogii pokazuje bowiem, że ta część, która powstała na bazie kroniki Stryjkowskiego, stanowi kompilację około trzydziestu ustępów znajdujących się w różnych jej miejscach.

Korzystając z omawianej kroniki, Symeon Samuel nie był jednak aż tak bezkrytyczny jak może się wydawać z powyższych konstatacji. W przypadku dwóch, jakże kluczowych informacji, zignorował on przekaz swojego głównego źródła. Dotyczy to przede wszystkim fundamentalnej kwestii protoplasty rodowego. Stryjkowski nie pozostawił w swojej kronice wątpliwości, że Sanguszkowie wywodzili się od szóstego syna Olgierda, którym był „Fiedor Sanguszko, z którego naród książąt kosserskich i kowelskich Sanguszków”59. Tymczasem według Symeona Samuela: „Giedymin miał siedm synów: [...] Lubarta, z którego domostwo nasze poszło" (s. 1/177).

Koncepcję Lubartowego pochodzenia zaczerpnąć musiał z piśmiennictwa historycznego, gdyż - jak wspomniano - przekaz z jednego źródła można było podważyć tylko na podstawie informacji zawartej w innym. Ponadto, jak się zaraz przekonamy, w pamięci fundacyjnej Sanguszków jeszcze w początkach XVI w. funkcjonowało przeświadczenie o Olgierdowym rodowodzie. W tej sytuacji staje się pewne, że opracowując swoje dziełko, Symeon Samuel Sanguszko korzystał także z dzieł historyków Korony Polskiej z drugiej połowy XVI w.: herbarzy Bartosza Paprockiego, który jako pierwszy wskazał Lubarta jako protoplastę Sanguszków, bądź też kroniki Joachima Bielskiego, który powtórzył tę informację Paprockiego w swoim bardzo popularnym dziele ${ }^{60}$. Niestety, tekst genealogii nie zawiera żadnej wskazówki, z którym konkretnym dziełem mógł mieć kontakt Symeon Samuel i wykorzystać jako źródło informacji.

Nie wydaje się prawdopodobne, aby przy tak skrupulatnym korzystaniu z kroniki Stryjkowskiego Symeon Samuel mógł przeoczyć informację o Fiodorze Sanguszce, szóstym synu Olgierda. Należy

58 Dotyczy to przede wszystkim fragmentu genealogii: „Witenes z Ejrgoły z herbu Kolumnów przybył za króla polskiego Władysława Łokietka [roku] 1283” (Aneks, s. 1/177), tymczasem M. Stryjkowski, Kronika, t. 1, s. 331, podaje, że rok 1283 był datą objęcia przez Witenesa władzy na Litwie i że nastąpiło to za panowania w Polsce Leszka Czarnego.

${ }_{59}$ M. Stryjkowski, Kronika, t. 2, s. 57.

${ }^{60}$ B. Paprocki, Gniazdo cnoty, skąd herby rycerstwa sławnego Królestwa Polskiego, Wielkiego Księstwa Litewskiego, Kraków 1578, s. 1142; tenże, Herby rycerstwa polskiego, wyd. K.J. Turowski, Kraków 1858, s. 828; J. Bielski, Kronika polska Marcina Bielskiego nowo przez Joachima Bielskiego syna jego wydana, Kraków 1597, s. 622. 
stwierdzić, że w tym, jakże ważnym, punkcie świadomie odrzucił on przekaz Stryjkowskiego, uznając za wiarygodne dzieła koronnych historyków. Jak wytłumaczyć ten zadziwiający fakt? Wydaje się, że wpływ na taką decyzję miała wielka siła oddziaływania dzieł Paprockiego i Bielskiego za jego czasów, nie tylko w Koronie, ale też na Litwie. Symeon Samuel pragnął, aby zrekonstruowana przez niego wizja dziejów rodu pozostawała w pełnej zgodzie z przekonaniami genealogicznymi dominującymi w świadomości historycznej szlachty Rzeczypospolitej. Niewątpliwe sam podzielał te przekonania, skoro z taką energią postanowił ugruntować u swoich potomnych koncepcję Lubartowego pochodzenia. Przypomnijmy, że wprowadził on do imiennictwa gałęzi kowelskiej przydomek Lubartowicz, który miał utrwalić taką wizję początków familii.

Drugą zaś kwestią, w której książę Symeon Samuel zignorował kronikę Stryjkowskiego, były mityczne korzenie familii. Co prawda nie miał on wątpliwości co do rzymskiego pochodzenia tak Sanguszków, jak i całej szlachty litewskiej, ale kwestię tę zamknął lapidarnym stwierdzeniem: „Naprzód tedy przodkowie nasi z Włoch poszli” (s. 1/177), przesuwając przy tym w czasie moment przybycia Rzymian na Litwę dopiero na przełom XII i XIII w. I to wydaje się zaskakujące, gdyż na podstawie samej tylko kroniki Stryjkowskiego mógł on poprowadzić rodowód Sanguszków aż do I w. p.n.e., do samego Palemona i Prospera Kolumny ${ }^{61}$. Wyraźnie jednak nie był zainteresowany mitycznymi pradziejami swojego rodu, nad którymi z taką skwapliwością rozwodzili się staropolscy panegiryści. Był skoncentrowany wyłącznie na odtworzeniu właściwego rodowodu książąt Sanguszków.

Warsztat historyczny Symeona Samuela Sanguszki cechował się więc z jednej strony pragmatyzmem, skupiającym się na wydobyciu jak największej liczby zaszczytnych informacji o dziejach rodu Sanguszków, z drugiej zaś swoistym racjonalizmem, aby te wiadomości były w pełni wiarygodne i przekonujące.

\section{Pamięć rodu}

Tam, gdzie kończył się przekaz kronik, autor genealogii zmuszony był sięgnąć do własnej wiedzy o dziejach familii. Zasób wiadomości, jakim Symeon Samuel Sanguszko dysponował w tym zakresie, obejmował nie tylko fakty znane mu z autopsji. Jego wiedza musiała być znacznie bardziej rozległa, w przeciwnym wypadku nie byłby w stanie stworzyć kompletnej genealogii swojej familii. Pozostałą część informacji o swoich przodkach i krewnych zdobył dzięki kontaktom z innymi członkami rodu (zwłaszcza z jego bocznej gałęzi) albo zaczerpnął z zabytków kultury materialnej, tworzonych lub gromadzonych przez Sanguszków jako nośniki ważnych dla wspólnoty informacji. Pamięć autora składała się zatem nie tylko z komponentu biograficznego, ale także komunikacyjnego i kulturowego, co pozwala mówić o pamięci całego rodu jako źródle genealogii ${ }^{62}$. W rezultacie tę część dziełka, której treść nie pochodzi z kronik i herbarzy, można uznać za eksternalizację pamięci zbiorowej Sanguszków na początku XVII w.

Wspomnienia pochodzące z pamięci rodu zapełniają ponad połowę treści genealogii Symeona Samuela (ok. 60\% tekstu), co pokazuje, jak obfite było to źródło wiadomości. O ile jednak informacje te wyróżniają się pod względem ilościowym, o tyle znacznie gorzej prezentuje się ich jakość. Analizując treść, z łatwością można oddzielić fakty zaczerpnięte z kroniki od tych pochodzących z pamięci rodu. Te ostatnie są zwięzłe, pozbawione - poza nielicznymi przypadkami - dat, ograniczają się do podstawowych faktów genealogicznych (filiacja, koicja, urzędy).

Co zaś szczególnie widoczne, są to dane mocno niekompletne. To właśnie w tej części genealogii Symeon Samuel pozostawił wiele wolnych miejsc w celu uzupełnienia nieznanych mu bądź zapomnianych wiadomości. Najczęściej dotyczy to imion wzmiankowanych osób: aż 33 osób zostało odnotowanych bez imienia. Częste są także przypadki, gdy autorowi nie udało się przytoczyć jakiejkolwiek informacji biograficznej o danej osobie: dotyczy to 13 przypadków. Co więcej, dane przywołane z pamięci są

${ }^{61}$ M. Stryjkowski w obszernym rozdziale wywodzi Litwinów od Palemona albo Publiusza Libona; tenże, Kronika, t. 1, s. 65-81.

${ }^{62}$ Koncepcja pamięci zbiorowej za: M. Halbwachs, Społeczne ramy pamięci, tłum. i wstęp M. Król, Warszawa 1969; J. Assmann, Pamięć kulturowa, s. 45-71. 
w kilku miejscach przeinaczone (dotyczy to zwłaszcza imion i nazwisk), uproszczone i błędne ${ }^{63}$. Oparta na pamięci rodowej część genealogii ma postać „suchego” wykazu faktów genealogicznych, uszeregowanych według linii i pokoleń, stąd też nie ma żadnej wartości literackiej.

Z powyższej charakterystyki wynika, że informacje przytoczone z pamięci rodu mają znamiona typowe dla sposobu działania ludzkiej pamięci, zniekształcającej i zacierającej wspomnienia wraz z upływem czasu. Rzeczywiście, analiza tych informacji wykazuje, że autor dziełka nie korzystał z zabytków, które można by określić mianem pamięci kulturowej rodu, a które gwarantowałyby dokładność i kompletność zaczerpniętych stąd faktów. Może to zaskakiwać, skoro wiadomo, że Sanguszkowie od początku gromadzili i dbali o archiwalia rodowe ${ }^{64}$. Nawet współcześni byli przekonani, że genealogia księcia Symeona Samuela powstała na bazie ,autentyków domowych" - jak to wyraził Kasper Niesiecki ${ }^{65}$. Tymczasem autor dziełka nie korzystał z archiwów rodowych, gdyż nawet te nieliczne wzmianki z genealogii, które mogłyby wskazywać na sięgnięcie do takich materiałów, okazują się w istocie zniekształconymi wspomnieniami, niepokrywającymi się z rzeczywistością historyczną ${ }^{66}$. Omawiana treść utworu stanowi zapis całej wiedzy księcia, jaką zdobył on o swoich przodkach i krewnych z autopsji lub dzięki kontaktom $\mathrm{z}$ innymi przedstawicielami rodu.

Pomimo niedoskonałości tak pozyskanej wiedzy, zasób faktów genealogicznych odnotowanych przez Symeona Samuela jest imponujący, co stawia kulturę pamięci Sanguszków mimo wszystko w pozytywnym świetle. W części powstałej na bazie omawianego źródła wymienionych jest aż 76 osób: 43 z nich to książęta i księżne wywodzące się z rodu Sanguszków, 31 to osoby spokrewnione lub spowinowacone (głównie małżonkowie Sanguszków) oraz 2 osoby niezwiązane genealogicznie z rodem, ale mające istotny wpływ na dzieje familii. Ponadto 43 osoby zostały odnotowane z imienia i nazwiska, w przypadku 19 osób podano tytulaturę urzędniczą, a cały tekst wymienia w sumie 22 tytuły urzędnicze. Wśród wzmiankowanych członków rodu znalazły się nawet osoby zmarłe na początku XVI w., czyli ok. 120 lat przed spisaniem genealogii. Biorąc pod uwagę fakt niekorzystania z materiałów archiwalnych, musi to wzbudzać niemały podziw ${ }^{67}$. Co jednak szczególnie istotne - żadna z wymienionych w dziełku osób nie jest fikcyjna. Mimo że możemy wskazać braki, przeinaczenia lub pomyłki, ta część genealogii księcia Symeona Samuela opiera się wyłącznie na historycznych postaciach, i pod tym względem góruje nawet nad częścią opartą na kronice Stryjkowskiego ${ }^{68}$.

Analiza tej części pokazuje rodzaj i zakres wspomnień utrwalających się w pamięci zbiorowej Sanguszków. Najwięcej wiadomości odnosiło się do najbliższego kręgu rodzinnego autora i jego bezpośrednich przodków. Pamięć rodowodu Symeona Samuela sięgała nawet dalej niż 100 lat i obejmowała

${ }^{63}$ Najważniejsze błędy popełnione przez Symeona Samuela są następujące: księcia Michała Sanguszkowicza uznał za protoplastę wszystkich linii rodu (Aneks, s. 2/179); całkowicie pominął postać księcia Aleksandra Sanguszkowicza, założyciela linii koszyrskiej i niesuchojeskiej; księcia Fiodora z linii niesuchojeskiej, syna Andrzeja Aleksandrowicza, uznał za ojca tegoż Andrzeja (tamże, s. 2/179-180); księcia Lwa z linii koszyrskiej, syna Aleksandra i wnuka Andrzeja, uznał za ojca obu tych książąt (tamże, s. 5/182).

${ }^{64}$ Zob. K. Syta, Dzieje archiwum, s. 98 n.

${ }^{65}$ K. Niesiecki, Herbarz polski, t. 8, s. 234.

${ }^{66}$ Na korzystanie przez Symeona Samuela Sanguszkę z materiałów archiwalnych wskazywała informacja o księciu Romanie Sanguszce, że pisał się on „na Niesuchojeżach” (Aneks, s. 3/180), jednakże w świetle licznych dokumentów tegoż księcia opublikowanych w: Archiwum XX. Sanguszków w Stawucie, t. 6: 1549-1577, t. 7: 1554-1572 (Dyplomatariusz gałęzi niesuchojeżskiej, t. 1-2), oprac. Z.L. Radzimiński, B. Gorczak, Lwów 1910, passim, nie ulega wątpliwości, że książę Roman nigdy nie posługiwał się takim przydomkiem (podobnie jak pozostali przedstawiciele linii niesuchojeskiej nie używał on żadnej odmiejscowej nazwy osobowej). Podobne wrażenie można odnieść w miejscu, gdzie Symeon Samuel cytuje inskrypcję widniejącą na płycie nagrobnej księcia Dymitra Fiodorowicza Sanguszki (Aneks, s. 2/180), jednak porównanie tego fragmentu z rzeczywistą treścią tegoż epitafium (opublikowane w: Monografia XX. Sanguszków, t. 2, cz. 1, il. do s. 122; S. Zagórska, Halszka z Ostroga. Między faktami a mitami, Warszawa 2006, s. 44), wskazuje, że książę przytaczał tekst z pamięci.

${ }^{67}$ Jak pokazują ustalenia antropologów, tzw. pamięć komunikacyjna sięgała około 80-100 lat wstecz; J. Assmann, Pamięć kulturowa, s. 64-64.

${ }^{68}$ M. Stryjkowski, Kronika, t. 2, s. 75, na podstawie błędnego przekazu wcześniejszych kronik połączył w jedną postać księcia Lubarta i jego syna Fiodora Lubartowicza, tworząc fikcyjną postać Fiodora Lubarta. 
prapradziada Michała, zmarłego na początku XVI w. ${ }^{69} \mathrm{~W}$ wywodzie własnych przodków książę nie popełnił żadnego błędu i przedstawił precyzyjne informacje. W następnej kolejności w pamięci rodu utrwalały się informacje o przedstawicielach bocznych gałęzi. Tutaj pamięć Symeona Samuela już szwankowała, pojawiały się poważne błędy, niemniej jednak niemal cały rodowód, sięgający 100 lat wstecz, był możliwy do odtworzenia. Natomiast, jak już wspomniano, w pamięci zbiorowej bardzo rzadko utrwalały się informacje inne oprócz najważniejszych faktów biograficznych ${ }^{70}$, a jeszcze rzadziej - jakiekolwiek daty. Jakże znamienny jest fakt, że pisząc drugą część genealogii w latach 1629-1634, książę nie był w stanie podać daty rocznej swojego trzeciego ślubu - z Heleną z Gosiewskich, który odbył się w... $1627 \mathrm{r}^{71}$

\section{„Dryfująca luka”}

Tylko dla jednej osoby odnotowanej w genealogii nie sposób wskazać źródła informacji. Mowa o Dymitrze Lubartowiczu Sanguszce, który według informacji z genealogii miał być synem Lubarta Giedyminowicza, księciem łuckim, zmarłym w 1449 r., a pochowanym w łuckim zamku (Aneks, s. 2/179). Nie odnajdujemy go też w dziele Stryjkowskiego ani w żadnej innej XVI-wiecznej kronice polskiej i litewskiej. Fakt, że Niesiecki napisał o tej postaci, że „więcej o nim nigdzie czytać mi się nie dostało”, zdaje się potwierdzać, że informacja ta nie mogła pochodzić z tradycji kronikarskiej ${ }^{72}$. Z drugiej strony zaś ów Dymitr nie mógł funkcjonować w pamięci rodowej, gdyż wyżej pokazano już, iż w tym obszarze utrwalały się wspomnienia o postaciach historycznych, a takiego księcia nie odnajdujemy w rodowodzie Sanguszków. Wydaje się zresztą mało prawdopodobne, aby Symeon Samuel, bez podpierania się źródłami, był w stanie pamiętać przodka zmarłego blisko 150 lat przed spisaniem genealogii.

Wydaje się zatem, że sporządzając swoje dziełko, książę napotkał typowy przypadek tzw. dryfującej luki. Według badań antropologicznych powstaje ona pomiędzy pamięcią fundacyjną a pamięcią komunikacyjną wspólnoty i poszerza się wraz z upływem czasu i rotacją pokoleń (stąd też określenie „dryfująca” ${ }^{73}$. Początki familii, które Symeon Samuel odtworzył na podstawie kronik, kończyły się w 1397 r. na śmierci Lubarta Giedyminowcza. Tymczasem najstarszy „pamiętany” przezeń przedstawiciel rodu, prapradziad Michał, miał umrzeć dopiero w 1490 r., czyli aż 93 lata później (rys. 2). Autor genealogii musiał mieć świadomość, że w pierwszej połowie XV w. żył jakiś nieznany mu książę, będący „łącznikiem” pomiędzy Lubartem a najdawniejszymi pokoleniami, do których sięgał pamięcią. Pragnąc stworzyć dzieło kompletne, musiał tę lukę wypełnić. $Z$ trudnych do ustalenia przyczyn nazwał nieznanego księcia Dymitrem i wskazał dokładną datę jego śmierci: 1449 r. Znamienne, że od śmierci Lubarta i Michała Sanguszkowicza datę tę oddziela niemal taki sam okres, wynoszący około 50 lat. Wskazując tak dokładną datę śmierci oraz podając tytulaturę książęcą i miejsce pochówku, Symeon Samuel mógł dążyć do uwiarygodnienia fikcyjnej postaci, której wprowadzenie było konieczne dla zachowania kompletności familijnej genealogii.

${ }^{69}$ Symeon Samuel Sanguszko podaje datę śmierci Michała Sanguszkowicza: 1490 (Aneks, s. 2/179), która jednak w świetle ustaleń J. Wolffa, Kniaziowie, s. 448, nie jest poprawna (wg Wolffa najmłodszy syn księcia Sanguszki zmarł ok. 1511).

${ }^{70}$ Spośród innych ważnych wydarzeń z dziejów rodu Symeon Samuel Sanguszko odnotował jedynie fakt wymiany dóbr wołyńskich na majątki w województwach witebskim i mińskim, dokonany przez jego pradziada Wasyla z królową Boną w 1547 r. (Aneks, s. 5/182, brak daty rocznej). Przeprowadzka na wschodnie rubieże Wielkiego Księstwa Litewskiego dotyczyła jednak tylko linii kowelskiej, w związku z czym było to wydarzenie ważne przede wszystkim dla tej gałęzi rodu.

${ }^{71}$ Symeon Samuel Sanguszko podał jedynie pierwsze trzy cyfry daty: „162”, pozostawiając miejsce obok na uzupełnienie ostatniej cyfry (Aneks, s. 8/184). Ślub księcia z Heleną Marcybelą Gosiewską odbył się 6 V 1627 w Wilnie; M. Nagielski, Sanguszko Samuel Szymon, s. 512. Fakt ten może wskazywać, że druga część dziełka powstała bliżej 1634 niż 1629 r.

${ }^{72}$ K. Niesiecki, Herbarz polski, t. 8, s. 235.

${ }^{73}$ Zjawisko „dryfującej luki” (ang. floating gap) jest spotykane w genealogiach szlachty nowożytnej. Keith Thomas, na przykładzie genealogii rodów szlacheckich nowożytnej Anglii, tak opisał to zjawisko: „Niezliczone genealogie przeskakiwały od mitycznych praprzodków bezpośrednio do współczesności, będąc, jak wyraził się pewien antykwariusz, niczym głowa i nogi bez korpusu, dwa końce bez środka"; K. Thomas, Vergangenheit, Zukunft, Lebensalter. Zeitvorstellungen in England der früher Neuzeit, Berlin 1988, s. 27, cyt. za: J. Assmann, Pamięć kulturowa, s. 65. 


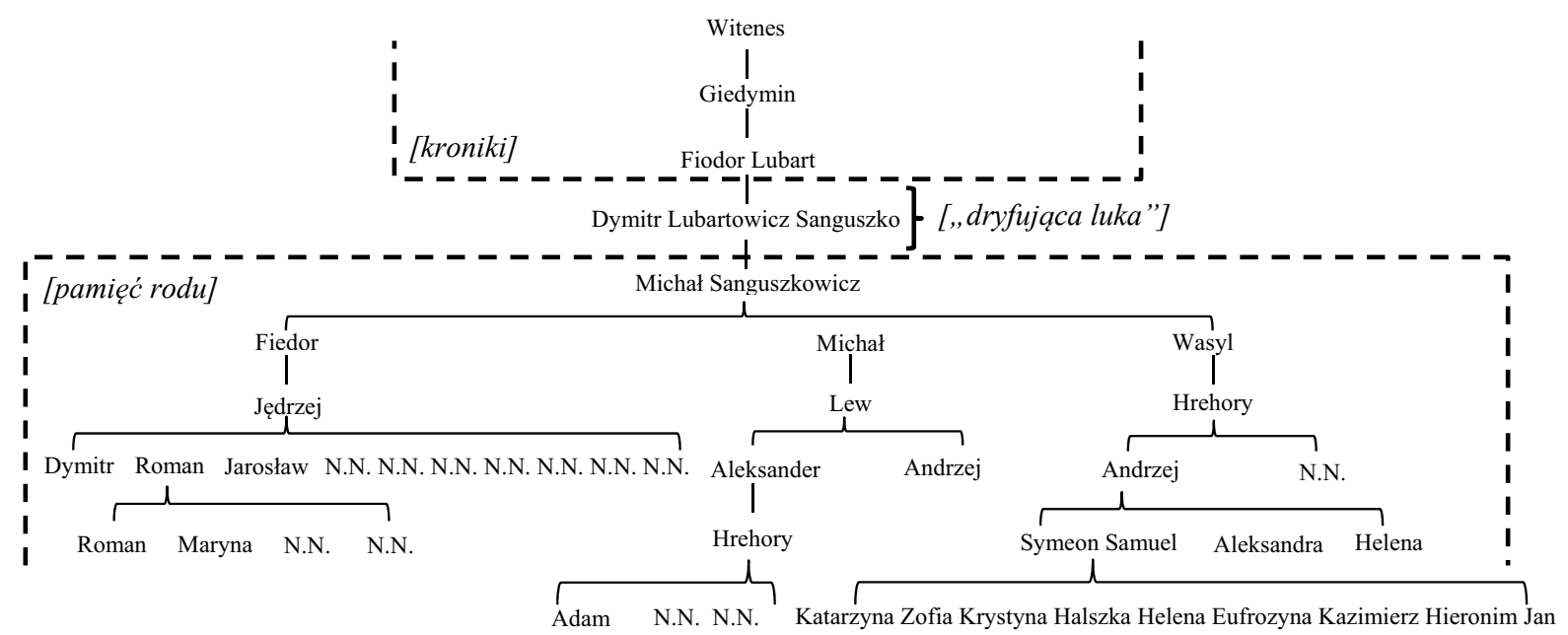

Rys. 2. Rodowód Sanguszków według genealogii Symeona Samuela Sanguszki, pokazujący zasięg danych zaczerpniętych w przeważającej mierze z kronik oraz z pamięci rodu, a także zasięg tzw. dryfującej luki

\section{Znaczenie genealogii}

Omawiany zabytek był nie tylko pokłosiem historyczno-genealogicznej pasji księcia Symeona Samuela. Dziełko to zostało stworzone dla określonych celów. Po pierwsze, genealogia miała wytworzyć „nową” tożsamość Sanguszków jako potomków Lubarta Giedyminowicza. Po drugie zaś miała przyczynić się do rozwiania wątpliwości w zakresie rodowodu Sanguszków, z którym na początku XVII w. kronikarze i heraldycy mieli spory kłopot.

\section{Waga zabytku dla rodu Sanguszków}

Aby w pełni zrozumieć, dlaczego książę Symeon Samuel tak bardzo zainteresował się dziejami swojej familii, należy cofnąć się do ostatnich dekad XVI w., kiedy to w rodzie Sanguszków nastąpiły poważne zmiany tożsamościowe ${ }^{74}$. Były one wywołane unią lubelską, wskutek której doszło do weryfikacji pozycji i znaczenia ruskiej magnaterii w Polsce i na Litwie. Na przełomie XVI i XVII w. kresowi książęta musieli na nowo określić swoją rangę i wywalczyć sobie odpowiednio wysokie miejsce w hierarchii elit Rzeczypospolitej.

W tych okolicznościach ród Sanguszków dokonał reorganizacji obrazu własnej przeszłości. Na plan pierwszy wysunięte zostały te informacje, które były źródłem największej dumy i sławy, wykraczającej poza granice Litwy i obejmującej Koronę (przede wszystkim pokrewieństwo z Jagiellonami oraz sławne czyny wybitnych przedstawicieli familii). Natomiast na plan dalszy odsunięto i w końcu zmarginalizowano te wspomnienia, które przynosiły ograniczony splendor. Dotyczyło to przede wszystkim właściwego protoplasty familii, księcia Sanguszki, który przez długi czas był podstawowym czynnikiem samoidentyfikacji wspólnoty. Mimo to Sanguszko został pod koniec XVI w. zapomniany przez swoich potomków, a zanik patronimiku Sanguszkowicz, używanego w roli nazwiska rodowego, był tego najlepszym świadectwem. W takich okolicznościach w pamięci familii wytworzyła się luka, którą należało „wypełnić” nowym protoplastą, tak aby wzmocnić tożsamość rodu i potwierdzić prawa do książęcego tytułu. W tym to celu Sanguszkowie ze starszej gałęzi, koszyrskiej, wprowadzili na początku XVI w. nowy patronimik: Olgierdowicz. Olgierdowy rodowód od samego początku stanowił element tożsamości familii, nie może więc dziwić, że do tych właśnie wspomnień odwołali się książęta ze starszej

74 Jako że przemiany tożsamościowe Sanguszków na przełomie XVI i XVII w. obszernie omawiam w artykule Nowożytny ród szlachecki, s. 509-523, nie przytaczam tu odniesień do obszernych źródeł i literatury, odsyłając do wspomnianego artykułu. 
linii rodu. Opozycyjne stanowisko zajął jednak Symeon Samuel Sanguszko, który, jak wiemy, uznał w latach 20. XVI w. ród Sanguszków za potomków Lubarta Giedyminowicza,

Zastanawiające, dlaczego wskazał on jako protoplastę familii właśnie księcia Lubarta. Bardziej zaszczytnym przodkiem musiał być przecież wielki książę Olgierd, praprzodek dynastii Jagiellonów. Decyzję Symeona Samuela należy thumaczyć wspomnianą wyżej chęcią ,adaptacji” pamięci rodu do wizji początków Sanguszków, która w początkach XVII w. upowszechniała się w świadomości genealogicznej Rzeczypospolitej za sprawą dzieł Paprockiego i Bielskiego. Nie chcąc stać w sprzeczności z tymi dziełami, książę postanowił wykorzystać tę sytuację na korzyść swojej familii. Zgodność z herbarzami Paprockiego zapewniała pamięci o dynastycznym rodowodzie Sanguszków nadzwyczaj trwałe zabezpieczenie w postaci dzieł, które uchodziły niemal za niekwestionowane źródło wiedzy o genealogii rodów szlacheckich. Ranga Sanguszków jako książęcej familii wywodzącej z „królewskiego narodu książąt litewskich" stawała się prawdą powszechną i niepodważalną.

Nie może zatem dziwić, że książę Symeon Samuel dołożył wszelkich starań, aby taka właśnie pamięć fundacyjna na trwałe zakorzeniła się w świadomości potomnych. W tym właśnie celu wprowadził on szereg nowych symboli rodowych: patronimik Lubartowicz, herb Kolumny czy przydomek: z Kowla. Niemniej kluczową rolę w tym procesie miała odegrać genealogia rodowa Sanguszków. Jak pamiętamy, została spisana na pergaminie i połączona $\mathrm{z}$ drogocennym modlitewnikiem francuskim. W ten sposób powstała swego rodzaju ,relikwia” rodowa, która zgodnie z zaleceniem autora miała być przekazywana z pokolenia na pokolenie. Informacje i wspomnienia eksternalizowane na kartach dziełka zostały wyniesione do rangi obligatoryjnego zasobu wiedzy dla każdego członka wspólnoty rodowej. Dzięki temu pamięć o Lubartowym pochodzeniu miała już nigdy nie zaniknąć w świadomości książąt Sanguszków.

Genealogia Symeona Samuela odniosła ogromny sukces na polu utrwalenia „nowej” wizji dziejów rodu. Od początku dziełko funkcjonowało w rodzie Sanguszków jako kanon wiedzy genealogicznej o dziejach familii. Ustalony wyżej fakt, że niemal każdy z potomków Symeona Samuela w XVII i XVIII w. posiadał własny egzemplarz dziełka, świadczy o tym najlepiej. Sporządzając nowe kopie, Sanguszkowie przepisywali zasadniczy tekst genealogii literalnie, zachowując nawet nieaktualne sformułowania, np. mające charakter osobistych wyznań autora ${ }^{75}$. W ten sposób treść uległa „kanonizacji”, stając się odporna na działanie czasu ${ }^{76}$. Dysponując własnymi kopiami, Sanguszkowie dodawali do genealogii informacje o kolejnych generacjach rodu. Dzięki temu każdy kolejny przedstawiciel familii mógł z łatwością wskazać swoje miejsce w rodowodzie, sięgającym samego Lubarta Giedyminowicza. Nie dziwi zatem, że przekonanie o pochodzeniu od tego księcia niezwykle mocno utrwaliło się w świadomości Sanguszków. Prawnuk autora genealogii, książę Paweł Karol Sanguszko, założywszy nową rezydencję rodową w Lewartowie na Lubelszczyźnie, doprowadził w 1744 r. do zmiany nazwy miejscowości na Lubartów ${ }^{77}$, a jeszcze długo w XIX w. jego potomkowie byli nazywani Lubartowiczami ${ }^{78}$.

\section{Znaczenie źródła dla staropolskiej genealogii}

W latach 20. XVII w., gdy książę Symeon Samuel pisał genealogię, w staropolskim piśmiennictwie historycznym panowała niezgodność co do rodowodu książąt Sanguszków. Jak już wspomniano, powstałe na Litwie kroniki Macieja Stryjkowskiego, opierając się na wcześniejszych latopisach litewskich,

75 Najlepszym tego przykładem jest fragment genealogii, w którym książę Symeon Samuel Sanguszko pisze w pierwszej osobie: „Potym z woli Bożej pojąłem znowu za małżonkę Helenę Marcybellę Korwinównę Gosiewską, wojewodziankę smoleńską, roku 162[.] dnia [.] maja" (Aneks, s. 8/184). Fragment ten został literalnie (pomijając drobne pomyłki) skopiowany w rękopisie N.N. (Pawła Karola Sanguszki?) z 1709/1711 (AN, ASang, rkps 558, s. 10) i rękopisie Krystyny Sanguszkówny z 1743 r. (tamże, s. 20), musiał więc znajdować się także w nieznanym rękopisie z 1692/1711 r.

${ }^{76} \mathrm{O}$ znaczeniu „kanonu” dla struktury konektywnej wspólnot opartych na pamięci zob. J. Assmann, Pamięć kulturowa, s. 34.

77 H. Seroka, Geneza i symbolika herbu Lubartowa, w: Lubartów i ziemia lubartowska, red. W. Śladkowski, B. Gąsior, Lubartów 1993, s. 33-39.

${ }^{78}$ Harfiarz. Zbiór pieśni patriotycznych i narodowych opracowany przez Stefana Surzyńskiego i wydany w 1890 r. w Tarnowie został zadedykowany „Jaśnie Oświeconemu Księciu Eustachemu Lubartowicz-Sanguszce” (tamże, s. III). 
wskazywały Olgierda jako praprzodka rodu. Z kolei dzieła z obszaru Korony Polskiej, autorstwa Bartosza Paprockiego i Joachima Bielskiego, twierdziły, że protoplastą był Lubart Giedyminowicz. Wiedza o innych przedstawicielach familii ograniczała się do kilku sławnych kniaziów z gałęzi niesuchojeskiej, głównie hetmana Romana Sanguszki ${ }^{79}$. O dwóch pozostałych liniach, koszyrskiej i kowelskiej, zaledwie wiedziano, że istnieją. Stryjkowski był jeszcze w stanie wymienić obie gałęzie ${ }^{80}$, ale już Paprocki wspomniał tylko o jednej z nich, koszyrskiej, o kowelskiej nie czyniąc nawet najmniejszej wzmianki ${ }^{81}$.

Jako bibliofil i pasjonat dziejów szlacheckich, książę Symeon Samuel musiał mieć świadomość, jak niewiele informacji o Sanguszkach, a zwłaszcza o gałęzi kowelskiej, można odnaleźć we współczesnych mu kronikach i herbarzach. Był to z pewnością kolejny powód, dla którego zajął się on dziejami familii i podjął próbę ostatecznego uregulowania kwestii rodowodu. Genealogia powstała zatem nie tylko na wewnętrzny użytek Sanguszków, to jest dla wzmocnienia ich tożsamości oraz dumy, ale także w celach - nazwijmy to - naukowych. Miała bowiem skorygować i uzupełnić ówczesny stan wiedzy o dziejach rodu Sanguszków. O takim przeznaczeniu najlepiej świadczy fakt, że autor oraz jego potomkowie udostępniali treść dziełka obcym osobom zainteresowanym historią familii. Już kaznodzieje głoszący mowy na pogrzebie autora utworu w 1639 r., Andrzej Hączel Mokrski i Tomasz Dygoń, musieli znać jej treść, skoro obaj wspomnieli Dymitra Lubartowicza Sanguszkę, księcia, jak pamiętamy, „wykreowanego" przez Symeona Samuela ${ }^{82}$. Z kolei w 1731 r., jak wspomniano, genealogia została udostępniona Józefowi Andrzejowi Załuskiemu, o czym ten nie omieszkał pochwalić się w jednym ze swoich listów.

Nie zaskakuje zatem, że genealogia Symeona Samuela już w latach 40. XVII w. zaczęła oddziaływać na staropolskie piśmiennictwo historyczno-genealogiczne. Pierwszym dziełem, w którym odnajdujemy informacje z interesującego nas utworu, jest Orbis Polonus Szymona Okolskiego. Na kartach trzeciego tomu tego herbarza, wydanego w Krakowie w 1645 r., ukazany został rodowód Sanguszków. Rzecz ciekawa, według Okolskiego protoplastą familii był, owszem, książę Lubart, ale nie Giedyminowicz, lecz Olgierdowicz ${ }^{83}$. Dominikanin podjął zatem próbę pogodzenia sprzecznych koncepcji pochodzenia Sanguszków, próbę nieudaną, gdyż zamiast rozstrzygać problem, gmatwał go jeszcze bardziej, tworząc trzecią - Olgierdowo-Lubartową - wersję rodowodu. Natomiast wśród kolejnych pokoleń ukazanych w Orbis Polonus odnajdujemy Dymitra Lubartowicza Sanguszkę oraz jego synów: Fiodora, Michała i Wasyla, od których wywiedzione zostały trzy gałęzie rodu ${ }^{84}$. Informacje o tych książętach zostały zaczerpnięte $\mathrm{z}$ genealogii Sanguszków, są to jednak jedyne takie przypadki w całym herbarzu.

Z treści Orbis Polonus wynika jasno, że Okolski nie znał genealogii z autopsji, w przeciwnym wypadku nie podejmowałby karkołomnej próby pogodzenia Olgierdowej i Lubartowej koncepcji rodowodu. Natomiast wiedzę o owym Dymitrze i jego synach zaczerpnął od Andrzeja Hączla Mokrskiego, który wymienił tych samych książąt w kazaniu wygłoszonym na pogrzebie Symeona Samuela, a opublikowanym w Wilnie w 1639 r. Biorąc pod uwagę, że Okolski nie wspomniał o Dymitrze i jego potomkach w pierwszym tomie, przy okazji wzmianki o koszyrskiej gałęzi Sanguszków, można założyć, że zapoznał się z kazaniem Mokrskiego w latach 1641-1645 ${ }^{85}$. Choć w przypadku Orbis Polonus wpływ genealogii Symeona Samuela okazuje się tylko pośredni i ograniczony do kilku zaledwie informacji, przekaz utworu umożliwił, po raz pierwszy w staropolskiej historiografii, zaprezentowanie pełnego rodowodu Sanguszków, obejmującego wszystkie trzy gałęzie. Niemniej kwestia pochodzenia familii, zagmatwana dodatkowo przez Okolskiego, nadal pozostawała nierozstrzygnięta. Najlepiej świadczy

\footnotetext{
${ }^{79}$ M. Stryjkowski, Kronika, t. 2, s. 406-407, 416-419, wspomina tylko dwóch Sanguszków: Dymitra Fiodorowicza oraz jego młodszego brata Romana. Natomiast B. Paprocki (tenże, Gniazdo cnoty, s. 1142-1143; tenże, Herby rycerstwa, s. 830-831) wymienia czterech książąt (Fiodor Andrzejewicz, Dymitr Fiodorowicz, Roman Fiodorowicz, Roman Romanowacz) oraz trzy księżne (nieznaną z imienia córkę Fiodora oraz córki Romana Fiodorowicza: Mariannę, Aleksandrę i Fiodorę).

${ }^{80}$ M. Stryjkowski, Kronika, t. 2, s. 57.

81 B. Paprocki, Herby rycerstwa, s. 831.

82 A. Hączel Mokrski, Pogonia, k. B4v; T. Dygoń, Przemiana koni, k. B4r.

${ }^{83}$ S. Okolski, Orbis Polonus, t. 1-3, Kraków 1641-1645, tu t. 3, s. 81: „Linea Illustrissimae Domus Sanguszkonum: Lubarth sextus filius Olgierdi".

84 Tamże, s. 81-83.

85 Tamże, t. 1, s. 542.
} 
o tym dzieło Phoenix redivivus Jakuba Suszy z 1646 r., dedykowane księciu Adamowi Aleksandrowi Sanguszce z linii koszyrskiej, określonemu mianem „Olgierdowicza”"86.

Przełom w wiedzy o Sanguszkach nastąpił dopiero w latach 50. XVII w. Stało się to za sprawą kolejnego z wielkich staropolskich heraldyków, Wojciecha Kojałowicza-Wijuka. W swoim Herbarzu rycerstwa Wielkiego Księstwa Litewskiego zajął on jednoznaczne stanowisko w kwestii pochodzenia Sanguszków, uznając ich za potomków księcia Lubarta Giedyminowicza ${ }^{87}$. Co prawda w znanych partiach dzieła nie stwierdził on wprost, że czerpał informacje z genealogii Symeona Samuela, niemniej analiza przedstawionego przezeń rodowodu Sanguszków nie pozostawia co do tego żadnych wątpliwości. Najdobitniej świadczą o tym obecne w herbarzu daty śmierci książąt Dymitra Lubartowicza i jego syna Michała, odpowiednio 1449 i 1495 r.: nie ulega wątpliwości, że zostały zaczerpnięte z dziełka księcia Symeona Samuela ${ }^{88}$. Fakt ten dowodzi nie tylko, że Kojałowicz korzystał bezpośrednio z genealogii, ale też uznawał ja za wiarygodne źródło do dziejów Sanguszków. Z pewnościa jej przekaz miał istotny wpływ na to, że ostatecznie uznał on Lubarta Giedyminowicza za protoplastę familii ${ }^{89}$. Biorąc pod uwagę, że jeszcze w Historia Litvanae z 1650 r. Kojałowicz twierdził, że Sanguszkowie pochodzą od Olgierda, należy stwierdzić, że do genealogii Symeona Samuela dotarł na początku lat 50. XVII w..$^{90}$

Niemniej litewski dziejopis w swoim herbarzu nie odwzorował wiernie rodowodu przedstawionego na kartach genealogii. Dokonał on kilku modyfikacji. Najważniejszymi było wprowadzenie drugiego syna Lubarta Giedyminowicza, Michała, który miał być założycielem rodu Czartoryskich, oraz ograniczenie liczby synów Dymitra Lubartowicza do dwóch: Fiodora, który miał założyć linię niesuchojeską, oraz Michała, protoplastę gałęzi koszyrskiej i kowelskiej ${ }^{11}$. O ile więc Kojałowicz nie podważał genealogii w fundamentalnej kwestii pochodzenia Sanguszków, o tyle nie uznawał dziełka za źródło niepodważalne, zajmując polemiczne stanowisko wobec dalszych jego fragmentów.

Herbarz rycerstwa Wielkiego Księstwa Litewskiego ugruntował Lubartową wersję rodowodu Sanguszków, rozstrzygając problem pochodzenia familii w staropolskiej historiografii. Od połowy XVII w. historycy i panegiryści działający w Koronie i na Litwie nie mieli wątpliwości, że Sanguszkowie byli potomkami Lubarta Giedyminowcza ${ }^{92}$. Istotny wpływ na ten proces miał także fakt, że w $1653 \mathrm{r}$. wygasła starsza gałąź rodu, koszyrska, która do końca podtrzymywała pamięć o Olgierdowych korzeniach familii. Drukowana genealogia Sanguszków, wydana w Warszawie w 1689 r. pt. Philosophia universa honori..., potwierdza recepcję Lubartowej koncepcji w historiografii staropolskiej w drugiej połowie XVII w. ${ }^{93}$

${ }^{86}$ J. Susza, Phoenix redivivus albo obraz starożytny chetmski Panny Matki Przenaświętszej, Zamość 1646.

${ }^{87}$ Herbarz znany z dwóch redakcji: łacińskojęzycznego Nomenclatora oraz polskojęzycznego Compendium. Jako że ta pierwsza nie zachowała się w całości, rodowód Sanguszków znamy tylko z Compendium; W. Kojałowicz-Wijuk, Herbarz rycerstwa W. X. Litewskiego tak zwany Compendium czyli o klejnotach albo herbach których familie stanu rycerskiego w prowincyach Wielkiego Xięstwa Litewskiego zażywaja, wyd. F. Piekosiński, Herold Polski, Kraków 1897, s. 10-13. W Nomenclatorze zachował się jednak fragment poświęcony Czartoryskim, w którym znalazła się także wzmianka o Sanguszkach: obydwa rody został określone potomkami Lubarta Giedyminowicza; tenże, Herbarz szlachty Wielkiego Księstwa Litewskiego zwany Nomenclator, wyd. F. Piekosiński, Herold Polski, Kraków 1905, s. 108.

${ }^{88}$ W. Kojałowicz-Wijuk, Herbarz rycerstwa... Compendium, s. 10-11. Nieco inna data śmierci księcia Michała jest niezawodnie przeoczeniem Kojałowicza.

${ }^{89}$ Według tenże, Herbarz szlachty... Nomenclator, s. 107-108, głównym argumentem Kojałowicza na rzecz Lubartowego pochodzenia Czartoryskich i blisko z nimi spokrewnionych Sanguszków był dokument Władysława Warneńczyka z 1442 r., który przyznawał Iwanowi, Aleksandrowi i Michałowi Czartoryskim prawo używania pieczęcie ze znakiem Pogoni. Na podstawie faktu, że król określił tych książąt mianem braci, a nie bratanków, Kojałowicz stwierdził, że nie mogli pochodzić od syna Olgierdowego, lecz brata Olgierda, co oznaczało, że ich przodkiem był Lubart Giedyminowicz. Można jednak domniemywać, że wzmianka o genealogii znajdowała się w tej partii Nomenclatora, która była poświęcona Sanguszkom.

90 W. Kojałowicz-Wijuk, Historia Litvanae, t. 1, Danzig 1650, s. 353-354, gdzie jako protoplasta Sanguszków: „Theodorus Lubartus, Sanguszkonum parens, a quo Kovelscii et Koszyrscii duces".

91 Tenże, Herbarz rycerstwa... Compendium, s. 11-12.

92 Nie oznaczało to jednak, że nie zdarzały się odstępstwa od takiej wizji dziejów rodowych. Najlepszym tego przykładem jest opis pogrzebu księcia Pawła Karola Sanguszki z 1751 r. autorstwa Pawła Giżyckiego, który inscenizował całą uroczystość. Opierając się na dziele Orbis Polonus Okolskiego, Giżycki zaprezentował zmarłego księcia jako potomka Lubarta Olgierdowicza; zob. P. Giżycki, Bieg życia chwalebny [...] Pawła Karola, Olgerdo Lubartowicza Sanguszka, Lublin 1751. Warto jednak podkreślić, że i dla Giżyckiego nie podlegało najmniejszej wątpliwości, iż protoplasta Sanguszków nosił imię Lubart.

93 J. Głuchowski, Philosophia universa honori et gloriae immortali [...] Casimiri Iosephi Antonii Sanguszko, Warszawa 1689. 
Genealogia ta była kopią rodowodu, który przestawił w swoim herbarzu Wojciech Kojałowicz-Wijuk. Fakt ten najlepiej pokazuje, jak wielką rolę odegrał litewski historyk w upowszechnianiu wersji dziejów Sanguszków zgodnej z genealogią księcia Symeona Samuela.

Ostatnim heraldykiem staropolskim, który korzystał z omawianego dziełka, był, o czym już wielokrotnie wspominano, Kasper Niesiecki. Wybitny polski historyk powołał się na genealogię w czwartym tomie swojego herbarza Korona Polska z 1743 r. ${ }^{94}$ Podobnie jak Kojałowicz, uznał przekaz genealogii za w pełni wiarygodny dla kwestii pochodzenia rodu. Opowiadając się jednoznacznie za Lubartową koncepcją, stwierdził, że ma tego „fundament” w postaci „genealogii domu tego książęcego [...], która, a znać z autentyków domowych od Lubarta Giedyminowicza, nie od Olgierdowicza, początki swoje zasięga" ${ }^{95}$. W rezultacie jako kolejny staropolski heraldyk wywiódł Sanguszków od Lubarta Giedyminowicza i jego syna Dymitra, ostatecznie potwierdzając swoim autorytetem taką wersję pochodzenia familii. Już jednak w dalszej części rodowodu nie czerpał tak bezkrytycznie z dziełka Symeona Samuela. Tam, gdzie jego treść nie wytrzymywała konfrontacji z innymi źródłami, zwłaszcza dokumentami, odrzucał przekaz genealogii. Tak samo jak Kojałowicz, Niesiecki ograniczył liczbę synów Dymitra Lubartowicza do dwóch, lecz za tzw. metryką wołyńską z 1528 r. podał inne ich imiona: Michał i Aleksander ${ }^{96}$.

Podsumowując, należy stwierdzić, że dziełko Symeona Samuela Sanguszki bardzo szybko stało się istotnym źródłem wykorzystywanym przez staropolskich historyków w celu odtworzenia genealogii rodu Sanguszków. O ile jednak historycy i heraldycy XVII i XVIII w. uznawali pełną wiarygodność utworu w odniesieniu do najdawniejszych dziejów, o tyle dysponując lepszymi materiałami źródłowym dla późniejszych pokoleń familii, krytykowali jego treść. Niemniej jednak księciu Symeonowi Samuelowi udało się osiągnąć najważniejszy „naukowy” cel, jaki postawił sobie przy opracowywaniu genealogii. Dzięki niej zdołał wpłynąć na piśmiennictwo historyczno-genealogiczne, tak aby ostatecznie rozstrzygnąć kwestię rodowodu swojej familii i znacząco poszerzyć zakres wiedzy o jej dziejach. Miarą sukcesu księcia może być fakt, że Lubartowa koncepcja pochodzenia Sanguszków mocno zakorzeniła się w polskiej literaturze genealogicznej i przetrwała aż do połowy XIX w. Ostatecznie została obalona dopiero przez Józefa Wolffa w 1886 r., który dowiódł, że Sanguszkowie bynajmniej nie wywodzili się od Lubarta Giedyminowicza, ale od kniazia Sanguszki, syna Fiodora Olgierdowicza ${ }^{97}$.

\section{Podstawa i zasady edycji}

Poniższa edycja jest rekonstrukcją oryginalnego tekstu genealogii Sanguszków, autorstwa księcia Symeona Samuela Sanguszki, z lat 1625-1634. Jej podstawą jest rękopis przechowywany w AGAD, w szóstym tomie kolekcji Michała Marczaka, na czterech kartkach pergaminowych oznaczonych jako s. 7-14 (paginacja późniejsza). Kartki te zostały wycięte z zeszyciku pergaminowego wszytego do modlitewnika francuskiego Horae Dive Virginis Marie secundum verum usum Romanum (Paryż 1505), dlatego też mają nieregularny kształt, wielkość ok. $16,5 \mathrm{x}$ ok. $10,5 \mathrm{~cm}^{98}$. Wykonano go z pergaminu nie najwyższej jakości - grubego i szorstkiego.

Tekst genealogii pisany jest staranną kursywą, w jednej kolumnie, z różną liczbą wierszy na stronie. Piszący starał się zachowywać marginesy: boczny (od zewnętrznej strony kartki), górny i dolny, nie mają one jednak równych wymiarów. Na marginesie bocznym dwukrotnie wprowadzono uzupełnienia do tekstu właściwego. Właściwy tekst dzieli się na akapity. Ich wydzielanie nie jest regularne: raz następuje wraz z biogramem kolejnego przedstawiciela rodu, innym razem wraz z nową informacją biograficzną. Naczelną

94 K. Niesiecki, Herbarz polski, t. 8, s. 234-241.

95 Tamże, s. 234.

96 Tamże, s. 236.

${ }^{97}$ Lubartową koncepcję pochodzenia Sanguszków podważył jako pierwszy K. Stadnicki, Synowie Gedymina, s. 261. Fakt pochodzenia rodu od Fiodora Olgierdowicza udowodnił J. Wolff, Ród Gedimina. Dodatki i poprawki do dzieł hr. K. Stadnickiego ,,Synowie Gedymina”, „, Olgierd i Kiejstut” i „Bracia Władysława Jagielly”, Kraków 1886, s. 119-121.

${ }^{98}$ Wymiary kolejnych kart są następujące: 1) ok. 162 x ok. $\left.10,5 \mathrm{~cm}, 2\right)$ ok. 16,6 x ok. 10,6 mm, 3) ok. 16,3 x ok. 10,4 cm, 4) ok. $16,1 \mathrm{x}$ ok. $10,5 \mathrm{~cm}$. Wskazuje to, że zeszycik in $8^{\mathrm{vo}}$, który Symeon Samuel dołączył do modlitewnika, powstał z jednej karty pergaminu o wymiarach ok. $42 \times 33 \mathrm{~cm}$. 
regułą wydaje się jednak poświęcanie nowych ustępów biogramom poszczególnych członkom wspólnoty, i taką też zasadę przyjęto $\mathrm{w}$ edycji. W tekście jest wiele pustych miejsc, pozostawionych bądź dla uzupełnienia brakujących informacji, bądź wprowadzenia nowych faktów biograficznych. Najczęściej są to niewielkie „okienka” przewidziane dla jednego wyrazu lub daty. Obok nich występują też większe luki, od jednego do sześciu wierszy, zostawione dla wprowadzenia informacji genealogicznych, a nawet całych biogramów.

W rękopisie występują trzy ręce: 1) autora genealogii, księcia Symeona Samuela Sanguszki, którą spisana została zasadnicza część dziełka w latach 1621-163499; 2) księżnej Katarzyny, wnuczki Symeona Samuela, którą dodano uzupełnienia w 1661 r.; 3) ręka nieznana (księżnej Anny, prawnuczki księcia Symeona Samuela?), którą wprowadzono uzupełnienia w 1692/1697 r.

Rękopis księcia Symeona Samuela Sanguszki zachował się w bardzo złym stanie. Tekst genealogii jest w wielu miejscach całkowicie wyblakły. Dotyczy to zwłaszcza pierwszych dwóch oraz ostatniej strony, które niemal w całości są obecnie niemożliwe do odczytania. Te fragmenty tekstu zrekonstruowano na podstawie późniejszych kopii genealogii. Najważniejszą z nich jest transkrypcja oryginału, która powstała w XIX w. w Dzikowie i zachowała się w Archiwum Narodowym w Krakowie ${ }^{100}$. Została ona wykonana bardzo starannie: zaznaczono w niej nieodczytane wyrazy, puste miejsca w tekście, początek stron i wersów. Porównanie jej treści z czytelnymi obecnie partiami rękopisu wskazuje nie tylko na wysoki poziom zgodności z oryginałem, ale także na umiejętność nieznanego autora odczytywania tekstu z epoki (był on zapewne archiwistą). Dlatego też omawiana transkrypcja posłużyła za najważniejsze źródło pozwalające ustalić nieczytelne obecnie fragmenty genealogii Symeona Samuela Sanguszki. W edycji oznaczono je przypisem tekstowym „a-a”.

Omówiona wyżej XIX-wieczna transkrypcja nie zawiera jednak wszystkich nieznanych obecnie partii dziełka, gdyż w chwili jej powstania oryginał był już w wielu miejscach niemożliwy do odczytania. W tych przypadkach postanowiono oprzeć się na przekazie dwóch XVIII-wiecznych kopii genealogii: rkps N.N. (Pawła Karola Sanguszki?) z 1709/1711 r. oraz rkps Krystyny Sanguszkówny z 1743 r. Chociaż nie powstały one na bazie oryginału, ale nieznanego rękopisu z przełomu XVII i XVIII w., mogą być pomocne w rekonstrukcji treści genealogii. Wynika to z faktu, że - jak już wskazano - dziełko to było traktowane jako tekst kanoniczny, stąd też starano się je kopiować możliwie najbardziej wiernie. Świadczy o tym także porównanie treści z oryginałem: rozbieżności okazują się w większości marginalne, niemające wpływu na zasadniczy przekaz utworu. Największą wiarygodność należy przypisać tym fragmentom, które występują w obu XVIII-wiecznych kopiach: fragmenty zrekonstruowane w ten sposób zostały oznaczone w edycji przypisem tekstowym „b-b”. Jednak niektóre partie zaczerpnięto tylko z jednego z tych rękopisów, co z kolei oznaczono odpowiednio przypisami „c-c” i „d-d”. Rozbieżności te wynikają z faktu, że rękopis Symeona Samuela był trudny do odczytania już pod koniec XVII w. (przyczyny tego stanu rzeczy omówiono wyżej).

Pomimo rekonstrukcji treści przy użyciu znanych kopii dziełka, tekst genealogii wciąż pozostaje w kilku miejscach nierozpoznany. Dotyczy to części utworu omawiającej czyny Lubarta Giedyminowicza. Ponieważ, jak wyżej ustalono, wiedzę o protoplaście familii Symeon Samuel Sanguszko czerpał wyłącznie z kroniki Stryjkowskiego, w przypisach rzeczowych zacytowano te fragmenty dzieła, których streszczeniem były niezachowane do dzisiaj partie genealogii.

Niniejszą edycję oparto na Instrukcji wydawniczej dla źródel historycznych od XVI do połowy XIX wieku, opracowanej przez Kazimierza Lepszego w 1953 r. W tekście zmodernizowano ortografię i interpunkcję, poprawiono też oczywiste pomyłki. W nawiasach kwadratowych oznaczono kolejność stron według oryginału. W przypisach rzeczowych podano najważniejsze odmianki tekstowe występujące w XVIII-wiecznych kopiach. W objaśnieniach dotyczących wymienionych osób daty nominacji urzędniczych podano tylko w przypadku urzędów wskazanych w genealogii.

99 Jakkolwiek we wstępie do genealogii Symeon Samuel Sanguszko otwarcie przyznaje się do autorstwa utworu, ostateczne potwierdzenie tożsamości jego ręki przynosi porównanie pisma rękopisu z pismem z listów tegoż księcia.

100 Transkrypcja przechowywana razem z omówionymi wyżej XVIII-wiecznymi kopiami genealogii; AN, ASang, rkps 558. O tym, że powstała na bazie oryginału, świadczy dołączony do niej krótki opis podstawy źródłowej: „Genealogia niniejsza znajduje się spisana na 4 kartach pergaminu grubego, wszytych na końcu książeczki do nabożeństwa in 80 [...] będącej niegdyś w posiadaniu Mikołaja Bogusława Zenowicza, potem Symeona Samuela Sanguszki i jego syna następnie”; tamże. 


\section{Aneks \\ Genealogia rodu Sanguszków księcia Symeona Samuela Sanguszki z lat 1625-1634}

aUważając tę książkę, której antiquitas godna jest zachowania, jakom się sam w niej kochał, tak starszemu synowi memu leguję, abya cjej nie oddawałc, aale takimże sposobem synowi swemu zostawił. A to dlatego ${ }^{a}{ }^{c}$ niemniejc, ${ }^{a} \dot{z} e$ tak tu przez mię Symeona ${ }^{a}{ }^{c}$ Samuela Lubartowicza Sanguszka z Kowlac, akasztelana witebskiego, origo familii [i] pożycie jest opisane ${ }^{a}$.

${ }^{\mathrm{b}}$ Naprzód tedy przodkowie nasi z Włoch poszli [roku] $1192^{\mathrm{b} 1}$. ${ }^{\mathrm{a}}$ Witenes $^{2} \mathrm{z}$ Ejrgoły ${ }^{\mathrm{a} 3} \mathrm{~b}_{\mathrm{z}}$ herbu ${ }^{\mathrm{c}} \mathrm{Ko}-$ lumnó $w^{c 4}$ aprzybył [?] za króla polskiego Władysława Łokietka [roku] $\underline{1283^{5}}$. Umarł, zostawiwszy po sobie syna Giedymina ${ }^{6}$ na Księstwie Litewskim roku $1315^{7}$. Giedymin miał 7 synów: Monwida; Narymunta; Olgierda, [z] którego syn Jagiełło poszedł, który królem polskim był; Kiejstuta, z którego Witold książę litewskie był; Lubarta, z którego domostwo nasze poszło ${ }^{8}$; Jawnuta i Koriata ${ }^{9}$. Umarł roku, ${ }^{\mathrm{a}}$ postrzelony, ${\underline{1328^{\mathrm{c}}}}^{\mathrm{p}}$.

${ }^{a}$ Lubart, syn Giedyminow[y], za żywota ojca swego wiarę chrześciańską ${ }^{\mathrm{b}}{ }^{\mathrm{b}} \mathrm{ruską}^{\mathrm{b}}{ }^{\mathrm{a}} \mathrm{przyjąq}^{11}$. Za żonę dał mu córkę swoją Włodzimierz książę wołyńskie ${ }^{12}$, ustąpiwszy mu w posagu części Woły-

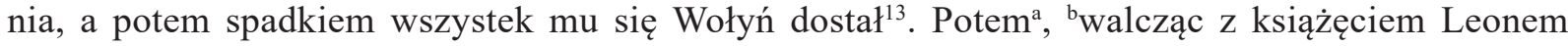

${ }^{a-a}$ - na podstawie transkrypcji oryginału z XIX w.; ${ }^{b-b}-$ na podstawie dwóch XVIII-wiecznych kopii: rkps N.N. (Pawła Karola Sanguszki?) z 1709/1711 oraz rkps Krystyny Sanguszkówny z 1743 r.; ${ }^{c-c}$ - tylko na podstawie rkps N.N. (Pawta Karola Sanguszki?) z 1709/1711 r.; ${ }^{d-d}$ tylko na podstawie rkps Krystyny Sanguszkówny z 1743 r.; ${ }^{\text {e-e }}$ - na marginesie; ${ }^{f}$ - puste miejsce na jeden wyraz; ${ }^{g}$ - pusty wers; ${ }^{h}$ - ok. 6 pustych wersów; ${ }^{i-i}$ - na marginesie; ${ }^{j-j}$ - przekreślone; ${ }^{k-k}$ - dopisane ręka Katarzyny Sanguszkówny w $1661 \mathrm{r}$; ${ }^{1-l}$ - dopisane nieznana ręka (Anny Sanguszkówny?) w 1692/1697 r.

${ }^{1}$ Nie jest jasne, na jakiej podstawie Symeon Samuel Sanguszko podał taką datę przybycia Rzymian na Litwę. Według M. Stryjkowski, Kronika, t. 1, s. 81, miało to nastąpić w 48 r. p.n.e.

${ }^{2}$ Witenes, zm. ok. 1316, wielki książę litewski, starszy brat (prawdopodobnie stryjeczny) Giedymina, z którym władał jako submonarcha; J. Tęgowski, Pierwsze pokolenia, s. 15-17.

${ }^{3}$ Ejragoła, miasto na Litwie, nad rz. Dubissą, w okręgu kowieńskim, $55 \mathrm{~km}$ na północ od Kowna; wg tradycji miejsce pochodzenia Giedyminowiczów; wg S. Zajączkowskiego, Przyczynki do hipotezy o pochodzeniu dynastii Giedymina ze Żmudzi, „Ateneum Wileńskie”, 4, 1927, s. 392 n., dynastia istotnie wywodziła się ze Żmudzi.

${ }^{4}$ Według rkps Krystyny Sanguszków z 1743 r. fragment ten brzmiał „z herbu Pogońców”: rozbieżność ta wynikała z nieczytelności fragmentu, o czym też świadczy rkps N.N. z 1709/1711 r., gdzie słowo Kolumnów jest mocno zniekształcone. Niemniej nie ulega wątpliwości, że pierwotnie tak brzmiał omawiany fragment, identyczne sformułowanie znajduje się bowiem u M. Stryjkowskiego, Kronika, t. 1, s. 331. Jako dodatkowy argument należy przytoczyć fakt, że Symeon Samuel Sanguszko wprowadził Kolumny do ówczesnej heraldyki rodowej Sanguszków. Wg legendy Witenes miał wywodzić się z Kolumnów, jednego z czterech rzymskich rodów, które przybyły na Litwę wraz z Palemonem i dały początek szlachcie litewskiej.

${ }_{5}$ Za: M. Stryjkowski, Kronika, t. 1, s. 331, przy czym M. Stryjkowski podaje, że rok 1283 był datą objęcia przez Witenesa władzy na Litwie, a nastąpiło to za panowania w Polsce Leszka Czarnego; wg J. Tęgowskiego, Pierwsze pokolenia, s. 15, Witenes objął władzę na Litwie dopiero ok. 1294 r., po śmierci Budiwida (Pukewera), prawdopodobnie swojego ojca.

${ }^{6}$ Giedymin, zm. 1341, wielki książę litewski, protoplasta Giedyminowiczów; J. Tęgowski, Pierwsze pokolenia, s. 20.

7 Za: M. Stryjkowski, Kronika, t. 1, s. 353; wg J. Tęgowskiego, Pierwsze pokolenia, s. 15, Giedymin objął władzę na Litwie ok. 1296 r. jako submonarcha Witenesa, a dopiero po jego śmierci rządził samodzielnie.

${ }^{8}$ Koncepcja Lubartowego pochodzenia Sanguszków za: B. Paprocki, Gniazdo cnoty, s. 1142; tenże, Herby rycerstwa, s. 828; J. Bielski, Kronika, s. 622.

9 Za: M. Stryjkowski, Kronika, t. 1, s. 381; wg J. Tęgowskiego, Pierwsze pokolenia, s. 19, Giedymin miał 8 synów, którzy urodzili się w następującej kolejności: Narymunt, Witold, Olgierd, Koriat, Jawnuta, Kiejstut, Lubart, Monwid.

${ }^{10}$ Za: M. Stryjkowski, Kronika, t. 1, s. 385; wg J. Tęgowskiego, Pierwsze pokolenia, s. 20, Giedymin został prawdopodobnie otruty.

11 Za: M. Stryjkowski, Kronika, t. 2, s. 29; wg J. Tęgowskiego, Pierwsze pokolenia, s. 235-237, Lubart, zm. przed 1384, ochrzczony prawdopodobnie ok. 1340 r. przy okazji ślubu z księżniczką wywodzącą się z Rurykowiczów wołyńskich; literatura przychyla się do poglądu, żeby była to córka lub siostra znanego w XIV w. Daniela Ostrogskiego.

${ }^{12}$ Na przełomie XIII i XIV w. władcą księstwa halicko-wołyńskiego był Jerzy I Lwowic; D. Dąbrowski, Rodowód Romanowiczów książąt halicko-wotyńskich, s. 197-217.

13 Za: M. Stryjkowski, Kronika, t. 1, s. 382; wg H. Paszkiewicza, Polityka ruska Kazimierza Wielkiego, wyd. 2, Kraków 2002, s. 85, Lubart opanował część Wołynia dopiero w 1340 r., po śmierci Bolesława Jerzego II. 
łuckim ${ }^{14}$, po którym wszystko ${ }^{\mathrm{b}}$ opanował, gdzie panem była ${ }^{\mathrm{b}}{ }_{\text {Wszystkiego }}{ }^{\mathrm{b}}$ Wołynia, i wiele ruskich ${ }^{\mathrm{a}}$ ${ }^{b} k s i a ̨ z ̇ a ̨ t ~ p o d b i w s z y{ }^{\mathrm{b}}{ }^{\mathrm{a}}$ wojną, aż do węgierskich gór panował roku $\underline{1330}^{15}$. Podjął potym wojnę przeciw Łokietkowi królowi polskiemu, z którym długo walczył, wiele bitew szczęśliwych mając ${ }^{16}$. Potym, za nastąpieniem króla Kazimierza polskiego, który zebrawszy wojsko niemałe, dobywał Lwowa ${ }^{\mathrm{b}}$ pod Lubartem $^{\mathrm{b}}{ }^{\mathrm{a}} \mathrm{w}$ wziął go przez ${ }^{\mathrm{a}}$ podanie roku $1340,{ }^{\mathrm{b}} \mathrm{gdzie}^{\mathrm{b}}{ }^{\mathrm{a}} \mathrm{w}$ szystkie państwa jego opanował, $\mathrm{a}^{\mathrm{a}}{ }^{\mathrm{b}} \mathrm{z}$ ugody, choć przez niechęć, niektóre wrócił, obowiązując się sobie przez to każdego ${ }^{\mathrm{a}}{ }^{\mathrm{a}}$ nieprzyjaciela, o czem są listy w skarbie ${ }^{a}$ bi teraz ${ }^{\text {b17 }}$. Czego jednak król polski nie strzymawszy, roku 1349 wojsko zebrawszy znowu, [pod] ${ }^{a}$ Lubartem, Fiedorem na chrzcie mianowanym ${ }^{\text {a18 }}$, łucki i włodzimierski zamek ${ }^{a}$ wziął $[\ldots]^{19}$. Lubart $^{\mathrm{a}}[\ldots]$, z wojskiem podciągnąwszy roku $1350,{ }^{b}$ swoje ${ }^{\mathrm{b}}$ a zamki $^{\mathrm{a}}{ }^{\mathrm{b}}$ odzyskał, $\mathrm{a}^{\mathrm{b}}{ }^{\mathrm{a}}$ Lwowa nie mogąc dobyć, wszystkie włości około niego ${ }^{\mathrm{a}}$ splądrował, ${ }^{\mathrm{a}} \mathrm{i}$ tak pohulawszy, sobie te zamki ${ }^{\mathrm{a}}{ }^{\mathrm{Wydzierali}}{ }^{20}$. $\mathrm{Jako}^{\mathrm{b}}$ roku 1351 znowu Kazimierz, wziąwszy na pomoc króla Ludwika węgierskiego, pobrał zamki i brata Kiejstuta pojmał, ${ }^{b} k_{\text {tóry }}{ }^{\mathrm{b}}$ obietnicą ${ }^{\mathrm{a}}{ }^{\mathrm{b}}$ okrzczenia ${ }^{\mathrm{b}}$ abył wypuszczony ${ }^{\mathrm{a}}$, gdzie znowu z Lubartem Wołynia dobył, ${ }^{\mathrm{a}} \mathrm{Zamki}^{\mathrm{a}}{ }^{\mathrm{b}} \mathrm{zbiwszy}^{\mathrm{b} 21}$. ${ }^{\mathrm{a}} \mathrm{A}$ Kazimierz ${ }^{\mathrm{a}}$ podtenczas do Litwy ciągnął, o czem się dowiedziawszy, ${ }^{a}$ Lubart z Kiejstutem ${ }^{\mathrm{a}}{ }^{\mathrm{b}}$ sędomirską ${ }^{\mathrm{a}} \mathrm{z}$ ziemię aż do Zawichosta ${ }^{22}$ zwojował, mając wodza Pszonkę Pola$\mathrm{ka}^{\mathrm{a} 23}$, ${ }^{\mathrm{b}}$ który jednak ${ }^{\mathrm{b}}$ na Wiśle oszukanie uczynił, ${ }^{\mathrm{b}}$ co szyrzej w kronice ${ }^{\mathrm{b} 24}$. ${ }^{\mathrm{d}} \mathrm{Znow}{ }^{\mathrm{d}}$ roku 1353 , zebrawszy

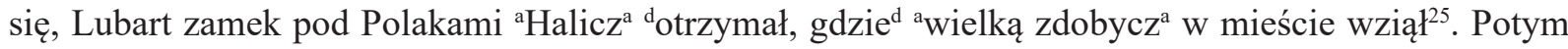
pociągnął ${ }^{\mathrm{a}}$ pod Zawichost ${ }^{\mathrm{a}}{ }^{\mathrm{d}}$ tamże i mieczem ${ }^{\mathrm{d}}$ siła państw popsował ${ }^{\mathrm{d}}$ Koronie Polskiej ${ }^{\mathrm{d} 26}$. Kazimierz,

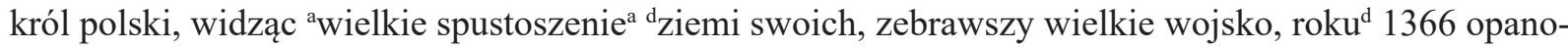
wał ${ }^{\mathrm{a}}$ wszystkie zamki wołyńskie ${ }^{27}$. Co widząc ${ }^{\mathrm{a}}$, ${ }^{\mathrm{d}}$ Lubart uciekł do Kazimierza ${ }^{\mathrm{d}}$ [...] ${ }^{\mathrm{a}}$ mając potęgę, nie chciał, i tak tego roku [wygnany był] ${ }^{28}$. Ale Kazimierz roku 1370 umarła ${ }^{\mathrm{d}}$ Tegoż roku Lubart, znowu

${ }^{14}$ Lew II Juriewicz, zm. 1323, ks. halicko-włodzimierski, panował wspólnie ze starszym bratem Andrzejem II; po ich jednoczesnej śmierci władcą księstwa został Bolesław Jerzy II; D. Dąbrowski, Rodowód Romanowiczów, s. 249-255.

15 Za: M. Stryjkowski, Kronika, t. 1, s. 382; wg H. Paszkiewicza, Polityka ruska, s. 16, nic nie wiadomo o działaniach zbrojnych Lubarta Giedyminowica w latach 20. i 30. XIV w.; wg J. Tęgowskiego, Pierwsze pokolenia ..., s. 235-236, Lubart móg1 być wtedy jeszcze zbyt młody.

${ }_{16}$ M. Stryjkowski, Kronika, t. 2, s. 7-9, przy czym imię Lubarta nie pojawia się wśród podanych tam książąt litewskich.

17 Za: tamże, s. 21; wg H. Paszkiewicza, Polityka ruska, s. 85-87, 108, w 1340 r. Lubart opanował część księstwa halicko-włodzimierskiego z Włodzimierzem, Łuckiem, Chełmem i Bełzem; Ruś Halicka znalazła się w rękach polskich.

${ }^{18}$ Za: M. Stryjkowski, Kronika, t. 2, s. 4, 41; wg J. Tęgowskiego, Pierwsze pokolenia, s. 235, na chrzcie Lubart otrzymał imię Dymitr; przypisywanie mu imienia Fiodor wynika z utożsamiania go z synem Fiodorem Lubartowicem.

19 Tu streszczenie fragmentu: M. Stryjkowski, Kronika, t. 2, s. 27: „[Kazimierz Wielki] tak bardzo za małą pracą jednego tego lata Luska albo Lucka, Włodimirza, Chełma i Brześcia zamków pod Litwą i Rusakami mocą dobył i obsadził Polakami, insze zaś zamki i twierdze dobrowolnie się podawały, za czym wołyńską wszystkę i belską, także beresciejską ziemię w moc swoję przywiódł”; wg H. Paszkiewicza, Polityka ruska, s. 117-119, w 1349 r. Kazimierz Wielki zorganizował wielką wyprawę na Ruś, w trakcie której opanował niemal całe władztwo Bolesława Jerzego II; w wyniku układu z królem polskim Lubart zachował Łuck.

20 Za: M. Stryjkowski, Kronika, t. 2, s. 28-29; wg H. Paszkiewicza, Polityka ruska, s. 120-123, w 1350 r. miała miejsce wyprawa litewska, powstrzymana dopiero pod Lwowem, w jej trakcie Lubart odzyskał Ruś włodzimierską.

${ }^{21}$ Za: M. Stryjkowski, Kronika, t. 2, s. 29; wg H. Paszkiewicza, Polityka ruska, s. 128-134, w 1351 r. Kazimierz Wielki wyruszył na Ruś z Ludwikiem Wielkim, w Lublinie król polski zachorował, a dowództwo na dalszą wyprawą objął Ludwik. Wobec wyraźnej przewagi wojska polsko-węgierskiego strona litewska zdecydowała się na układy: Kiejstut zgodził się na chrzest i inne ustępstwa, ale Polacy nie odzyskali księstwa włodzimierskiego. W 1352 r. miała miejsce kolejna wspólna wyprawa polsko-węgierska, lecz zakończyła się fiaskiem; być może w połowie tego roku Litwini dokonali odwetowego najazdu na Ruś.

22 Zawichost, miasto w woj. świętokrzyskim, nad rz. Wisłą, 17 km na północny zachód od Sandomierza.

${ }^{23}$ Piotr Pszonka, h. Nowina, rycerz polski, jeden z przewodników wypraw litewskich na ziemie polskie; B. Paprocki, Herby rycerstwa, s. 44.

24 Za: M. Stryjkowski, Kronika, t. 2, s. 29-30; wg H. Paszkiewicza, Polityka ruska, s. 134-135, pod koniec 1352 r. Kazimierz Wielki zorganizował wyprawę, w jej trakcie zawarł rozejm z książętami litewskimi.

${ }^{25}$ Za: M. Stryjkowski, Kronika, t. 2, s. 30; wg H. Paszkiewicza, Polityka ruska, s. 167-170, pomimo zawartego rozejmu, w 1353 r. Lubart trzykrotnie najechał Królestwo Polskie, niszcząc Lwów, Halicz i docierając pod Zawichost.

26 Za: M. Stryjkowski, Kronika, t. 2, s. 30.

27 Za: tamże, s. 41; wg H. Paszkiewicza, Polityka ruska, s. 231-232, w 1366 r. Kazimierz Wielki zorganizował wyprawę przeciwko Lubartowi, w jej trakcie opanował ziemię wołyńską.

${ }^{28}$ Tu streszczenie fragmentu: M. Stryjkowski, Kronika, t. 2, s. 41: „A Lubart, Fiedor na chrzcie, rzeczony książę włodimirskie, gdy prosił łaski, nie chciał na to pozwolić król, ale zaraz na Wołyń w dierżawy jego z wojskiem się ruszył i ciągnął dalej 
Kiejstuta brata na pomoc wziąwszy, dobył Włodzimirza ${ }^{\mathrm{d}} .[\ldots]^{\mathrm{a}}{ }^{\mathrm{z}}$ wojskiem Polskę splądrował ${ }^{29}$. [...] Za króla [węgierskiego] Ludwika [...] [Lubart] około Sędomierza, Lublina, aż do Zawichostu pociągnął [...] aż do Tarnowa mieczem i ogniem spustoszył przez krakowską [...] splądrował ${ }^{30}$. [2] Lubart, jako mógł, użytkował swoje zamki. Po śmierci króla Ludwika pokupił dwa starostwa roku $1382^{31}$. Roku 1386, gdy Jagiełło na Królestwo Polskie, Księstwo Litewskie mając, był wzięty, tedy Fiedor Lubart Sanguszko, książę łuckie, wołyńskie i włodzimierskie, za Jagiełła synowca się swego zapisował ${ }^{32}$. Potem roku 1396 otrzymał od króla Jagiełła siwierskie państwa, obowiązując się być pod posłuszeństwem, na co i listy dał, które w skarbie są ${ }^{\mathrm{a} 33}$. ${ }^{\mathrm{e}} 1397^{\mathrm{e}}$ umarł tego roku, ${ }^{\mathrm{a}} \mathrm{zostawiwszy}{ }^{\mathrm{a}}$ po sobie syna Dymitra Sanguszka, książęcia łuckiego.

Ten zmarł anno 1449 . Pochowany w łuckim zamku³.

Michajło Sanguszkowic ${ }^{35}$ miał trzech synów: Fiedora, Michajła, Wasyla. ${ }^{a}$ Sam umarła roku 1490.

Z ${ }^{a}$ Fiedora ${ }^{36}$ Jędrzej $^{37}$ syn $^{\text {a }}$, który miał żonę Despota, wojewody wołoskiego, [córkę] ${ }^{38}$. Miał trzech synów: Dymitra, Romana, Jarosława. Ten Fiedor znaczne dzieła swe, znosząc nieraz Tatary, okazując, umarł anno [ł]. Córek [miał] 7:

do włodimirskiego kraju, gdzie gdy żadnego odporu nie miał, Łucka, Włodimirza i Oleska zamków mocą dobył, a drugich przygrodków snadnie przez podanie dostał. A tak Lubarta Gedminowica, brata Olgerdowego i Kiejstutowego, z Wołynia wygnawszy i on wszystek kraj podbiwszy i zhołdowawszy”. Wg H. Paszkiewicza, Polityka ruska, s. 232-237, na mocy układu Kazimierza Wielkiego z książętami litewskimi z 1366 r., Lubart zachował Łuck, pozostałą część Wołynia podzielono między innych książąt.

${ }^{29}$ Tu streszczenie fragmentu: M. Stryjkowski, Kronika, t. 2, s. 45: „A potym [...] Lubart wołyński prosto od Włodimirza z gotowym wojskiem litewskim i ruskim ciągnęli do Polski, a przeszedłszy lubelską ziemię i zwojowawszy w niej wszystki wołości, wtargnęli do sendomirskiej ziemie, którą także zburzyli i splundrowali, aż do Łysej Góry”. Wg S.M. Kuczyńskiego, Lubart, w: PSB, t. 17, Wrocław 1972, s. 576, po śmierci Kazimierza Wielkiego w 1370 r., Lubart z książętami litewskimi odzyskał ziemię włodzimierską.

${ }^{30}$ Tu streszczenie fragmentu: M. Stryjkowski, Kronika, t. 2, s. 50-51: „A w tym czasie [roku 1376] [...] Lubart też Fiedor książę wołyńskie z Łucka i Włodimirza [...] z Wołyńcami i z Rusakami przez wielkie pustynie przyszli do lubelskiej ziemie, a tam złączywszy wszyscy mocy swoje i potym rozszykowawszy się na różne zagony, z lubelskiej ziemie, przez sendomirską ciągnąc, przyszli aż do Sanu rzeki na Podgórze, [...] tam wszytki krainy polskie między Sanem i Wisłą rzekami leżące wszerz i wzdłuż zwojowali aż do Tarnowa i za Sendomirz daleko w drugą stronę, [...] bardzo wielką wielkość ludzi i slachty, także Bogaczów, w domach bezpiecznych brali i wiązali, a drugich niewczas uciekających, po drogach i polach różnych imali”. Wg S.M. Kuczyńskiego, Lubart, s. 576, w 1376 r. Lubart wziął udział w najeździe na Polskę, który w kolejnym roku spowodował odwetową wyprawę Ludwika Węgierskiego i zajęcie Wołynia; Ludwik nadał ziemie włodzimierską i łucką Lubartowi jako swojemu lennikowi.

${ }^{31}$ Za: M. Stryjkowski, Kronika, t. 2, s. 69-70. Wg S.M. Kuczyńskiego, Lubart, s. 576, po śmierci Ludwika Węgierskiego w 1382 r. Lubart kupił od starostów węgierskich Kamieniec, Olesko, Horodło, Łopatyn, Krzemieniec, Peremyl i Siestratyn.

${ }^{32}$ Za: M. Stryjkowski, Kronika, t. 2, s. 75; wg J. Tęgowskiego, Pierwsze pokolenia, s. 240, w tym czasie Lubart Giedyminowic już nie żył, a gwarantem unii Polski i Litwy w 1386 r. był jego syn Fiodor Lubartowic, zm. ok. 1431, ks. łucki i włodzimierski.

${ }_{33}$ Nowogród Siewierski, miasto na Ukrainie, nad rz. Desną, w obwodzie czernichowskim, ok. 170 km na północny wchód od Czernichowa; za: M. Stryjkowski, Kronika, t. 2, s. 108; wg J. Tęgowskiego, Pierwsze pokolenia, s. 240-241, w 1393 r. Fiodor Lubartowicz otrzymał księstwo siewierskie w zamian za utracone księstwo włodzimierskie; wcześniej, w 1386 r., utracił księstwo łuckie.

${ }^{34}$ Fiodor Lubartowic nie pozostawił po sobie spadkobierców; J. Tęgowski, Pierwsze pokolenia, s. 241. Dymitr Sanguszko, niewzmiankowany przez M. Stryjkowskiego, jest postacią fikcyjną, wprowadzoną przez Symeona Samuela Sanguszkę w celu zachowania ciągłości genealogicznej pomiędzy protoplastą Lubartem a znanymi mu przedstawicielami rodu Sanguszków.

${ }^{35}$ Michał Sanguszkowic, zm. ok. 1511, ks., najmłodszy syn księcia Sanguszki (zm. 1454/1463), miał 2 synów: Jarosława i Wasyla; J. Wolff, Kniaziowie, s. 448.

${ }^{36}$ Fiodor Sanguszko, zm. 1547/1548, ks. z linii niesuchojeskiej, starosta włodzimierski, bracławski i winnicki, marszałek ziemi wołyńskiej, syn Andrzeja Sanguszki (por. niżej), miał 4 synów: Dymitra, Andrzeja, Romana i Jarosława oraz 2 córki: Fiodorę i Marię, jeden z najbardziej zasłużonych książąt wołyńskich w walkach z Tatarami i Moskwą, m.in. inicjator napadu Kozaków na Oczaków z 1545 r.; M. Machynia, Sanguszko (Sanguszkowicz) Fiodor (Fedor, Teodor), w: PSB, t. 34, s. $480-482$.

37 Andrzej Sanguszko, zm. 1534/1535, syn Aleksandra Sanguszkowicza, ks. z linii niesuchojeskiej, starosta włodzimierski, marszałek ziemi wołyńskiej, miał 2 synów: Romana i Fiodora (por. wyżej) oraz 7 córek: Zofię, Marię, Fiodorę, Wasylisę, Helenę, Hannę, N.N.; Sanguszko (Sanguszkowicz) Andrzej Aleksandrowicz, w: PSB, t. 34, s. 468-469.

${ }^{38}$ Hanna Despotówna, zm. 1579, córka Jovana Brankovicia, syna ostatniego despoty Serbii, ż. 1v. Fiodora Sanguszki, 2v. Mikołaja Zbaraskiego; M. Machynia, Sanguszko (Sanguszkowicz) Fiodor (Fedor, Teodor), s. 482. 
Wydał pierwszą ${ }^{39}\left[^{\mathrm{g}}\right]$ Drugą ${ }^{40}\left[^{\mathrm{g}}\right]$ Trzecią ${ }^{41}\left[^{\mathrm{g}}\right]$ Czwartą ${ }^{42}\left[^{\mathrm{g}}\right]$ Piątą ${ }^{43}\left[{ }^{\mathrm{g}}\right]$ Szóstą ${ }^{44}\left[{ }^{\mathrm{g}}\right]$ Siódmą $^{45}\left[^{\mathrm{g}}\right]$

${ }^{a}$ Syn Dymitr Sanguszko ${ }^{46}, w^{\mathrm{a}}$ młodym wieku swoim będąc ${ }^{a}$ pobudzony od książęcia Ostrogskiego ${ }^{\mathrm{a} 47}$, najachawszy na Ostróg ${ }^{48}$, wziął księżną Ilianę [sic!] Ostrogską ${ }^{49}$, która już była zmówiona za Zgórkę [sic! ${ }^{50}$, o co się król August wziął. ${ }^{a} Z$ a czem do Czech $^{\mathrm{a}}$ do Jaromierza ${ }^{51}$ zjachał i z panną, ale Zborowski ${ }^{52}$, niespodziewanie w kilkuset człeka napadłszy, pannę odjął, samego długo broniącego się zabił, gdzie z cesarskiego rozkazania epitafium z napisem wystawiono: „Tut leżit Dimitr Sanguszko kniezia wielikoje litewskie okrutnie od "Zborowskiego a szlachcica polskiego zdradziecko i okrutnie zamordowany" 53 , roku $1553^{54}$.

[3] Drugi syn Fiedorow[y], Roman Sanguszko ${ }^{55}$, na Niesuchojeżach ${ }^{56}$ się pisał, wojewoda bracławski, hetman polny Wielkiego Księstwa Litewskiego, włodzimierski, żytomierski [starosta]. Ten ojczyźnie służąc, znacznie w młodym wieku swym Tatary bijał. Potym hetmański regiment wziąwszy, naprzód mając wojsko pod swym regimentem, szedł ku granicom moskiewskim. Tamże na polach czaśnickich ${ }^{57}$, mając 1800 człeka i z piechotą, zbił Moskwy do $\underline{8}$ tysięcy, ni mając w swym wojsku tylo $\underline{12}$ zabitych, a ranionych $\underline{30}$, roku $1567 \underline{20}$ dnia lipca ${ }^{58}$. Znowu tegoż roku Moskwa z Uły ${ }^{59}$ do Suszy $^{60}$ w kilku tysięcy, mając 3 tysiące Tatarów, ciągnęła, starszych mając Osipa Szczerbatego ${ }^{61}$, a kniazia Juria Boratyńskiego ${ }^{62}$,

39 Zofia Sanguszkówna, zm. ok. 1540, księżna z linii niesuchojeskiej, ż. Fiodora Zasławskiego; Sanguszko (Sanguszkowicz) Andrzej Aleksandrowicz, s. 469.

${ }^{40}$ Maria Sanguszkówna, księżna z linii niesuchojeskiej, ż. Jerzego Holszańskiego Dubrowieckiego; tamże.

${ }^{41}$ Fiodora Sanguszkówna, zm. po 1557, księżna z linii niesuchojeskiej, ż. Michała Bohowitynowicza; tamże.

${ }^{42}$ Wasylisa Sanguszkówna, zm. 1576/1577, księżna z linii niesuchojeskiej, ż. Andrzeja Druckiego Sokolińskiego; tamże.

${ }^{43}$ Helena Sanguszkówna, zm. 1561, księżna z linii niesuchojeskiej, ż. 1v. Piotra Massalskiego, 2v. Stanisława Skopa; tamże.

${ }^{44}$ Hanna Sanguszkówna, zm. 1561, księżna z linii niesuchojeskiej, ż. Iwana Sapiehy; tamże.

${ }^{45}$ N.N., księżna z linii niesuchojeskiej, ż. Fiodora Czartoryskiego; tamże.

${ }^{46}$ Dymitr Sanguszko, zm. 1554, ks. z linii niesuchojeskiej, starosta żytomierski, czerkaski i kaniowski. Starając się o rękę Halszki Ostrogskiej, przy poparciu Konstantego Ostrogskiego, najechał w 1553 r. Ostróg, poślubił ją siłą i uprowadził. Znieważony Zygmunt August, jako opiekun księżnej, skazał go w 1554 r. na infamię i gardło. Uciekając do Austrii, Dymitr został doścignięty przez Marcina Zborowskiego nieopodal Jaromierza w Czechach i pojmany, zmarł w wyniku poniesionych w trakcie walki ran, prawdopodobnie dobity; M. Machynia, Sanguszko Dymitr, w: PSB, t. 34, s. 471-473.

${ }^{47}$ Konstanty Wasyl Ostrogski, ok. 1526-1608, ks., marszałek ziemi wołyńskiej, wojewoda kijowski; J. Wyrozumski, Ostrogski Konstanty Wasyl, w: tamże, s. 489-495.

${ }^{48}$ Ostróg, miasto na Ukrainie, nad rz. Wilią, w obwodzie rówieńskim, ok. $110 \mathrm{~km}$ na południowy wschód od Łucka.

49 Elżbieta (Halszka) Ostrogska, 1539-1582, córka Ilii (Eliasza) Ostrogskiego i Beaty Kościeleckiej, ż. 1v. Dymitra Sanguszki, 2v. Łukasza Górki, 3v. Siemiona Olelkowicza; R. Żelewski, Górkowa Elżbieta, w: PSB, t. 8, Wrocław 1959-1960, s. 424-426.

${ }^{50}$ Łukasz Górka, ok. 1533-1573, wojewoda poznański; W. Dworzaczek, Górka Łukasz, w: tamże, s. 412-414.

${ }^{51}$ Jaromierz, miasto w Czechach, w kraju hradeckim, ok. 122 km na północny wschód od Pragi.

${ }_{52}$ Marcin Zborowski, zm. 1565, kasztelan kaliski i krakowski, wojewoda poznański; B. Paprocki, Herby rycerstwa, s. $145-146$.

${ }^{53}$ Epitafium w kościele św. Mikołaja w Jaromierzu wystawiono staraniem Romana Sanguszki na przełomie lat 50. i 60. XVI w.: na płycie znajduje się herb Pogoń oraz 2 inskrypcje: po polsku (?) i po łacinie. Inskrypcja polskojęzyczna: THV LIESZY KNIZE DIMITHR SANDUSCKOWYCZ STAROSTA CZYRKAWSKI Y KAYNOWSKY RODV WYELKIEGO KNIZE LYTHEWSKIE OLGIERDOWA KTHVREGO ZAMORDOWAL Y ZABIL NIESZLIACHTEHNICK MARCZIN ZBOROWSKI NIEMYAWSZY DO NIEGO ZADNY PRZYCINY 1554; cyt. za: Monografia XX. Sanguszków, t. 2, cz. 1, il. do s. 122.

${ }^{54}$ Data za: M. Stryjkowski, Kronika, t. 2, s. 406-407.

55 Roman Sanguszko, ok. 1537-1571, ks. z linii niesuchojeskiej, starosta żytomierski (1557), wojewoda bracławski (1566), hetman dworny litewski (1567 sprawca hetmaństwa dwornego, 1569 hetman dworny), jeden z najsłynniejszych i najwybitniejszych litewskich wodzów epoki; miał syna Romana Fiodora i 3 córki: Mariannę, Aleksandrę i Fiodorę; M. Machynia, Sanguszko (Sanguszkowicz) Roman, w: PSB, t. 34, s. 500-505.

56 Obecnie: Wola, wieś na Ukrainie, nad rz. Turią, w obwodzie wołyńskim, ok. 90 km na północ od Łucka. Roman Sanguszko nie pisał się „,na Niesuchojeżach”, gdyż nie używał żadnej odmiejscowej nazwy własnej; zob. dokumenty księcia w: Archiwum XX. Sanguszków, t. 7, passim.

${ }^{57}$ Czaśniki, miasto na Białorusi, nad rz. Ułłą, w obwodzie witebskim, ok. $80 \mathrm{~km}$ na południowy zachód od Witebska.

58 Za: M. Stryjkowski, Kronika, t. 2, s. 416.

59 Ułła, wieś na Białorusi, nad rz. Ułła, w obwodzie witebskim, ok. $70 \mathrm{~km}$ na zachód od Witebska.

${ }^{60}$ Susza, uroczysko między rz. Suszą i Ułłą, w obwodzie witebskim, ok. 100 km na wschód od Mohylewa.

${ }^{61}$ Osip Michałowicz Szczerbatow, zm. 1578, ks., wódz moskiewski; B. Paprocki, Herby rycerstwa, s. 830.

62 Jurij Fiodorowicz Boratyński, ks., wódz moskiewski; tamże. 
a nad Tatary Segit Murza ${ }^{63}$. Tamże za stoczeniem bitwy pogromił wojsko, starszych do więzienia wziąwszy i $\underline{80}$ innych znacznych, nie straciwszy tylo 3 zabitych, a rannych $\underline{30^{64}}$. Roku zaś $\underline{1568}$ września $\underline{20}$ dnia Ułę, zamek moskiewski, gdzie go przedtym nieraz dobywano, z wielką sławą swoją szturmem wzią ${ }^{65}$. Roku 1569 na sejmie chorągwie i więźnie oddawał ${ }^{66}$. Roku 1571 umarł gorączką, 12 dnia maja, wieku $34^{67}$. Miał małżonkę [ $\left.{ }^{7}\right]$ Chodkiewiczównę ${ }^{68}$ jedynaczkę, po której wziął był wiele majętności, dzieląc się z Pawłem Sapiehą ${ }^{69}$, kasztelanem kijewskim, który siostrę rodzona miał za soba z Hrehora Chodkiewicza ${ }^{70}$. Potomstwo Romanowe: syn Roman ${ }^{71}$ abez potomstwa ${ }^{a}$ zszedł. 3 zaś córki:

[4] Jedna, księżna ${ }^{\mathrm{M} M a r y n a}{ }^{\mathrm{a} 72}$, panną umarła.

Druga, księżna ${ }^{73}[\mathrm{f}]$, szła za pana [f] Radzimińskiego ${ }^{74}$ wojewodę podlaskiego, który w Moskwie bezpotomnie ${ }^{75}$ na poselstwie umarł, zapisawszy Radzymin [i] insze majętności; szła potym za księcia Prońskiego ${ }^{76}$ pana trockiego, z którym miała 2 synów $^{77}$ i córkę ${ }^{78}$, co teraz za panem Rafałem Leszczyńskim $^{79}$, wojewodą bełskim; szła potym za trzeciego, pana [ $\left.{ }^{\dagger}\right]$ Leszczyńskiego ${ }^{80}$, wojewodę brzeskiego kujawskiego, z którym nie mając potomstwa, umarła.

Trzecia, księżna ${ }^{81}$ [†], szła za książęcia Zasławskiego Janusza ${ }^{82}$, wojewodę wołyńskiego, z którą

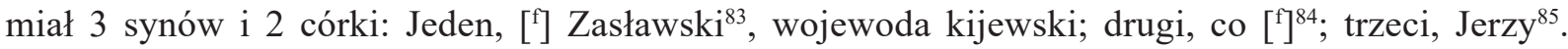

${ }^{63}$ Segit Murza, wódz tatarski; tamże.

${ }^{64}$ Za: M. Stryjkowski, Kronika, t. 2, s. 417. Bitwa na Suszy miała miejsce w sierpniu bądź na początku września 1567 r.; M. Machynia, Sanguszko (Sanguszkowicz) Roman, s. 502.

${ }_{65}$ Za: M. Stryjkowski, Kronika, t. 2, s. 417.

${ }^{66}$ Za: tamże, s. 418. Przekazanie jeńców i 4 dział zdobytych pod Ułłą nastąpiło 31 V 1569 na sejmie w Lublinie; M. Machynia, Sanguszko (Sanguszkowicz) Roman, s. 502.

${ }^{67}$ Za: M. Stryjkowski, Kronika, t. 2, s. 419.

${ }^{68}$ Aleksandra Chodkiewicz, zm. 1570, ż. Romana Sanguszki, córka Hrehorego Chodkiewicza (por. dalej), miała dwóch braci: Andrzeja i Aleksandra oraz siostrę Hannę (Annę), ż. Pawła Sapiehy (por. dalej); J. Jasnowski, Chodkiewicz Grzegorz, w: PSB, t. 3, Kraków 1937, s. 359 (błędnie podaje, że drugą córką Chodkiewicza była Zofia, ż. Filona Kmity). Synowie Hrehorego Chodkiewicza zmarli bezpotomnie w 1578 r. i dopiero wtedy potomstwo Romana Sanguszki i Aleksandry z Chodkiewiczów, występując razem z ciotką Hanną, przejęło fortunę brzostowickiej linii Chodkiewiczów; J. Wolff, Kniaziowie, s. 434.

${ }^{69}$ Paweł Sapieha, zm. 1580, starosta lubecki, kasztelan kijowski (1566); H. Lulewicz, Sapieha Pawet, w: PSB, t. 35, Warszawa-Kraków 1994, s. 131.

${ }^{70}$ Hrehory Chodkiewicz, ok. 1513-1572, hetman wielki litewski, kasztelan wileński, wojewoda witebski i kijowski; J. Jasnowski, Chodkiewicz Grzegorz, s. 359.

${ }^{71}$ Roman (Fiodor) Sanguszko, zm. 1591, ostatni ks. z linii niesuchojeskiej; M. Machynia, Sanguszko (Sanguszkowicz) Roman, S. 504.

72 Marianna Sanguszkówna, zm. przed 1587, księżna z linii niesuchojeskiej, zmarła jako panna; tamże.

${ }^{73}$ Fiodora Sanguszkówna, zm. 1597/1598, księżna z linii niesuchojeskiej, żona 1v. Stanisława Radzimińskiego, 2v. Aleksandra Prońskiego (ok. 1592), 3v. Andrzeja Leszczyńskiego (1596); M. Machynia, Sanguszko (Sanguszkowicz) Roman, s. 504.

${ }^{74}$ Stanisław Radzimiński, zm. ok. 1591, starosta liwski, kasztelan zakroczymski i czerski, wojewoda podlaski (1588); J. Choińska-Mika, Radzimiński Stanisław, w: PSB, t. 30, Wrocław 1987, s. 104.

75 Z małżeństwa z Fiodorą Sanguszkówną miał córkę Annę (ok. 1586-1604), ż. Rafała Leszczyńskiego (ok. 1604) (por. niżej) oraz syna Jana, studenta uniwersytetów w Bazylei, Strasburgu, Genewie i Padwie, zmarłego w młodym wieku; tamże, s. 104.

${ }^{76}$ Aleksander Proński, ok. 1550-1595, ks., starosta łucki, kasztelan trocki (1591); R. Żelewski, Proński Aleksander, w: PSB, t. 28, Wrocław 1984-1985, s. 507-509.

77 Juliusz Eliasz Proński, zm. 1613, oraz Aleksander Oktawian Proński, zm. 1638; tamże.

${ }^{78}$ Córka Fiodory Sanguszkówny, Anna, nie pochodziła z małżeństwa z Aleksandrem Prońskim, ale ze Stanisławem Radzimińskim (por. wyżej).

79 Rafał Leszczyński, 1579-1636, kasztelan wiślicki i kaliski, wojewoda bełski (1619); M. Sipayłło, Leszczyński Rafał, w: PSB, t. 17 , s. $135-138$.

${ }^{80}$ Andrzej Leszczyński, ok. 1559-1606, starosta nakielski, wojewoda brzeski kujawski (1591); W. Dworzaczek, Leszczyński Andrzej, w: tamże, s. 101-103.

${ }^{81}$ Aleksandra Sanguszkówna, zm. 1602, księżna z linii niesuchojeskiej, ż. Janusza Januszewicza Zasławskiego (1578); M. Machynia, Sanguszko (Sanguszkowicz) Roman, s. 504.

82 Janusz Zasławski, zm. 1629, ks., wojewoda podlaski i wołyński (1604); J. Wolff, Kniaziowie, s. 601-602.

83 Aleksander Zasławski, zm. 1629, kasztelan wołyński, wojewoda bracławski i kijowski (1628); tamże, s. 603.

${ }^{84}$ Konstanty Zasławski, zm. ok. 1615; tamże, s. 602.

85 Jerzy Zasławski, 1592-1636, starosta włodzimierski; tamże, s. 602. 
Córka jedna ${ }^{86}$ szła za pana Ostroroga ${ }^{87}$, wojewodę poznańskiego; druga ${ }^{88}$ za pana Szczęsnego Herbołta $^{89}$.

Te siła za sobą majętności domu Sanguszków zabrali90.

Trzeci syn Fiedorow[y], Jarosław Sanguszko ${ }^{91}$, ten po zwadzie zdradziecko przez sekret zabity.

Tu się skończyła analogia [sic!] pierwszego syna Michajłowego, Fiedora. [5] Poczyna się analogia drugiego syna a Michajłowego ${ }^{a}$, Michajła też.

Michajło $^{92}$ miał syna Lwa ${ }^{93}$, ten na Koszarzu ${ }^{94}$ został.

Lew miał syna Aleksandra ${ }^{95}$ i Andrzeja ${ }^{96}$.

Aleksander miał z Ościkówny ${ }^{97}$ Hrehora.

Hrehory Sanguszko ${ }^{98}$ na Koszyrsku, kasztelan brasławski, pojął za małżonkę Annę Hołowczyńską99, z której miał syna książęcia Adama ${ }^{100}$ i 2 córki: jedna szła do klasztoru ${ }^{101}$, druga ${ }^{102}$ za pana Krasickiego $^{103}$, starostę odolińskiego.

Książę Adam Sanguszko ${ }^{104}$, wojewoda podolski, a teraz wołyński, pojął za małżonkę pannę [†] Uchańską $\left.{ }^{105} \cdot{ }^{[}\right]$

Tu się poczyna analogia trzeciego syna Michajłowego, Wasyla.

Wasyl Sanguszko ${ }^{106}$ na Kowlu ${ }^{107}$ został, który [6] " ${ }^{\text {potym }}$ a przefrymarczył z królową Boną Sforzą na wianowne jej dobra, na Smolany ${ }^{108}$, Obolce ${ }^{109}$ i Horwol ${ }^{110}$. Pojął za małżonkę [ ${ }^{\mathrm{f}}$ ] Skoruciankę ${ }^{111}$, miał i drugą [żonę] Zofią Łoszczankę ${ }^{112}$. Ze Skorucianki miał syna ${ }^{113}$.

${ }^{86}$ Zofia, ż. Jana Ostroroga; tamże, s. 602-603.

${ }^{87}$ Jan Ostroróg, 1565-1622, kasztelan poznański, wojewoda poznański (1610); W. Dworzaczek, Ostroróg Jan, w: PSB, t. 24, Wrocław 1979, s. 506-511.

${ }^{88}$ Elżbieta, ż. 1v. Jana Szczęsnego Herburta, 2v. Maksymiliana Przerembskiego.

${ }^{89}$ Jan Szczęsny Herburt, 1567-1616, starosta dobromilski, mościcki i wiski, sekretarz królewski.

${ }^{90}$ Dotyczy Fiodory i Aleksandry Sanguszkówien, które jako jedyne dziedziczki fortuny niesuchojeskiej linii Sanguszków wniosły te dobra do obcych domów.

${ }^{91}$ Jarosław Sanguszko, zm. 1564, ks. z linii niesuchojeskiej, 4 IX 1564 w trakcie uczty u Owdotii Czetwertyńskiej w Jarowiczach k. Łucka został skrytobójczo zastrzelony przez rotmistrza Żelecha; J. Wolff, Kniaziowie, s. 433.

${ }_{92}$ Michał Aleksandrowicz Sanguszko, zm. przed 1501, ks. z linii koszyrskiej, miał syna Andrzeja i 2 córki N.N.; tamże, s. $436-437$.

${ }^{93}$ Lew Sanguszko, ok. 1536-1571, ks. z linii koszyrskiej, syn Aleksandra Andrzejewicza, rotmistrz jazdy litewskiej, miał syna Hrehorego; M. Machynia, Sanguszko (Sanguszkowicz) Lew, w: PSB, t. 34, s. 497.

${ }_{94}$ Kamień Koszyrski, miasto na Ukrainie, w obwodzie wołyńskim, ok. 110 km na północ od Łucka.

${ }_{95}$ Aleksander Andrzejewicz Sanguszko, ok. 1508-1565, ks. z linii koszyrskiej, marszałek hospodarski, miał syna Lwa; M. Machynia, Sanguszko (Sanguszkowicz) Aleksander, w: PSB, t. 34, s. 467-468.

${ }^{96}$ Andrzej Michałowicz Sanguszko (zm. 1560), ks. z linii koszyrskiej, marszałek hospodarski, sprawca woj. kijowskiego, starosta łucki, miał syna Aleksandra; M. Machynia, Sanguszko (Sanguszkowicz) Andrzej Michałowicz, w: PSB, t. 34, s. 469-471.

${ }_{97}$ Hanna Ościkówna, zm. 1584, ż. Lwa Sanguszki; M. Machynia, Sanguszko (Sanguszkowicz) Lew, s. 497.

${ }_{98}$ Hrehory Sanguszko, zm. 1602, ks. z linii koszyrskiej, kasztelan lubaczowski i bracławski (1598); I. Kaniewska, Sanguszko (Sanguszkowicz) Hrehory (Grzegorz, Hrihory), w: PSB, t. 34, s. 488-490.

99 Zofia Hołowczyńska, zm. 1605, ż. 1v. Hrehorego Sanguszki (ok. 1593), 2v. Stanisława Mniszcha; tamże, s. 490.

${ }_{100}$ Adam Aleksander Sanguszko (por. dalej, przyp. 104).

101 Aleksandra Sanguszkówna, 1594-1625, lwowska klaryska (ok. 1612), zasłynęła z pobożności; I. Kaniewska, Sanguszko (Sanguszkowicz) Hrehory (Grzegorz, Hrihory), s. 490.

102 Anna Sanguszkówna, ż. Jerzego Krasickiego (1621); tamże.

103 Jerzy Krasicki, zm. 1645, starosta odoliński; K. Chłapowski, Starostowie niegrodowi w Koronie 1565-1795 (Materiały źródtowe), Warszawa 2017, s. 200.

104 Adam Aleksander Sanguszko, ok. 1590-1653, ks. z linii koszyrskiej, kasztelan bracławski i kijowski, wojewoda podolski (1621) i wołyński (1629), ostatni przedstawiciel linii koszyrskiej; W. Kłaczewski, Sanguszko Adam Aleksander, w: PSB, t. 34 , s. $464-467$.

105 Katarzyna Uchańska, zm. 1650, ż. Adama Aleksandra Sanguszki (1615); tamże, s. 467.

106 Wasyl Sanguszko, zm. ok. 1557, ks. z linii kowelskiej, dzierżawca świsłocki i jezierzycki, w 1543 r. dokonał wymiany dóbr z królową Boną: w zamian za Kowel na Wołyniu otrzymał Smolany i Obolce w woj. witebskim i Horwol w woj. mińskim; M. Machynia, Sanguszko Wasyl, s. 513-514.

107 Kowel, miasto na Ukrainie, w obwodzie wołyńskim, ok. $70 \mathrm{~km}$ na północny zachód od Łucka.

108 Smolany, wieś na Białorusi, w obwodzie witebskim, ok. $80 \mathrm{~km}$ na południe od Witebska. 
Hrehory Sanguszko ${ }^{114}$, starościc świsłocki i jezierzycki, pojąwszy małżonkę Zofią Hornostajównę ${ }^{115}$, wojewodziankę brzeską, ${ }^{i}$ ta po [jego] śmierci szła za Kmitę Czarnobylskiego ${ }^{i 116}$, a mając syna Andrzeja i córkę [ $\left.{ }^{\mathrm{f}}\right]$, w młodym wieku umarł. Anno $15^{\left[{ }^{\mathrm{f}}\right]}$

Córka ${ }^{117}$ szła $\left.{ }^{\mathrm{g}}\right]$

Syn Andrzej ${ }^{118}$ pojął za małżonkę Zofią Sapieżankę ${ }^{119}$, kasztelankę kijewską, z Chodkiewiczówny drugiej siostry, co za książęciem Romanem Sanguszkiem była. Z tej miał niemało dzieci, pomarli. Zostali po śmierci: syn Symeon; Aleksandra ${ }^{120}$, panną umarła; Helena ${ }^{121}{ }^{j}$ za Steczyńskiego ${ }^{122}$, podsędka mińskiego, wydana ${ }^{j}$.

Syn Symeon Samuel Lubartowicz Sanguszko ${ }^{123}$ [7] z Kowla, wojewoda witebski, suraski starosta, miał za małżonkę pierwiej ${ }^{\mathrm{i}}$ anno $1606^{\mathrm{i}}$ Annę Zawiszankę ${ }^{124}$, jedynaczkę na Rakowie ${ }^{125}$, z którą mieszkając przez lat 13 , miał z nią $\underline{3}$ synów, a $\underline{8}$ córek.

Jedna, Katarzyna ${ }^{126}$, wydana za pana Stetkiewicza ${ }^{127}$, chorążego orszańskiego.

Druga, Zofia ${ }^{128}$, dorósłszy, panną będąc, umarła anno $\underline{1629}$.

Trzecia, Krystyna ${ }^{129}\left[{ }^{\mathrm{g}}\right]$ Czwarta, Halszka ${ }^{130}\left[{ }^{\mathrm{g}}\right]$ Piąta, Helena ${ }^{131}\left[{ }^{\mathrm{g}}\right]$ Szósta, Eufrozyna ${ }^{132}\left[^{\mathrm{g}}\right]$

A dwie poumierały małemi.

Sama też po porodzeniu Eufrozyny w tydzień umarła dnia 13 alipca anno $1619^{\text {a133 }}$.

Syn ${ }^{\mathrm{a}}$ pierwszy, Kazimierz ${ }^{\mathrm{a} 134},{ }^{\mathrm{k}}$ anno $\underline{1655}$, gdy Moskwa Księstwo Litewskie wojowała, w ucieczce czy też w majętności swej od Moskwy zginął. W bezżeństwie żyłk.

${ }^{109}$ Obolce, wieś na Białorusi, nad rz. Obolanką, w obwodzie witebskim, ok. $85 \mathrm{~km}$ na południe od Witebska.

${ }^{110}$ Horwal, miasto na Białorusi, nad rz. Berezyną, w obwodzie homelskim, ok. 60 km na zachód od Homla.

111 Hanna Skorucianka z Mładetycz, zm. 1533, ż. Wasyla Sanguszki; M. Machynia, Sanguszko Wasyl, s. 514.

112 Zofia Łoszczanka, ż. 1v. Piotra Szumborskiego, 2v. Wasyla Sanguszki; tamże.

113 Oraz 3 córki: Hannę, Mariannę i Magdalenę; tamże.

114 Hrehory Sanguszko, zm. 1555, ks. z linii kowelskiej; J. Wolff, Kniaziowie, s. 451-452.

115 Zofia Hornostajówna, zm. przed 1563, córka Iwana Hornostaja, wojewody nowogrodzkiego, ż. 1v. Hrehorego Sanguszki, 2v. Filona Kmity Czarnobylskiego; tamże, s. 451-452.

116 Filon Kmita Czarnobylski, ok. 1530-1587, rotmistrz, starosta orszański, wojewoda smoleński; J. Eberle, Kmita Filon Czarnobylski, w: PSB, t. 13, Wrocław 1967-1968, s. 88-89.

117 Fiodora Sanguszkówna, księżna z linii kowelskiej, ż. 1v. Zygmunta Giedrojcia, 2v. Piotra Starbrowskiego; J. Wolff, Kniaziowie, s. 452.

118 Andrzej Sanguszko, zm. 1591, ks. z linii kowelskiej; tamże, s. 452.

119 Zofia Sapieżanka, córka Pawła Sapiehy, kasztelana kijowskiego (zob. przyp. 69) i Anny Chodkiewiczówny, siostry Aleksandry, ż. Romana Sanguszki; ż. 1v. Andrzeja Sanguszki, 2v. Andrzeja Tyszkiewicza; tamże, s. 452.

${ }^{120}$ Aleksandra Sanguszkówna, księżna z linii kowelskiej, zmarła jako panna; tamże, s. 452.

${ }^{121}$ Helena Sanguszkówna, księżna z linii kowelskiej, ż. Krzysztofa Żyżemskiego; tamże, s. 452-453.

${ }_{122}$ Mężem Heleny był Krzysztof Żyżemski (zm. 1633), ks., podsędek miński; tamże, s. 452.

${ }^{123}$ Symeon Samuel Sanguszko, zm. 1638, ks. z linii kowelskiej, kasztelan mścisławski i witebski, wojewoda witebski (1626), starosta suraski (ok. 1629); M. Nagielski, Sanguszko Samuel Szymon, s. 510-513.

${ }_{124}$ Anna Zawiszanka, zm. 1619, ż. Symeona Samuela Sanguszki; tamże, s. 513.

${ }^{125}$ Raków, miasto na Białorusi, nad rz. Isłoczą, w obwodzie mińskim, ok. 35 km na zachód od Mińska. Anna Zawiszanka jako dziedziczka Rakowa wniosła tę majętność Sanguszkom; tamże, s. 512.

126 Katarzyna Sanguszkówna, księżna z linii kowelskiej, ż. Jana Stetkiewicza; tamże, s. 512.

127 Jan Stetkiewicz, zm. 1634, chorąży orszański; W. Kojałowicz-Wijuk, Herbarz rycerstwa... Compendium, s. 101.

${ }_{128}$ Zofia Sanguszkówna, zm. 1629, księżna z linii kowelskiej, zmarła jako panna; M. Nagielski, Sanguszko Samuel Szymon, s. 512.

${ }^{129}$ Krystyna Sanguszkówna (zm. przed 1647), księżna z linii kowelskiej, ż. Jana Mikołaja Rudominy Dusiackiego; H. Lulewicz, Rudomina Dusiacki Jan Mikołaj, w: PSB, t. 32, Wrocław 1991, s. 512.

${ }^{130}$ Halszka (Elżbieta Anna) Sanguszkówna, księżna z linii kowelskiej, zakonnica u benedyktynek w Wilnie, imię zakonne Aurea; M. Nagielski, Sanguszko Samuel Szymon, s. 512.

${ }^{131}$ Helena Sanguszkówna, księżna z linii kowelskiej, zakonnica u karmelitanek bosych w Wilnie, imię zakonne Eufrazja od św. Kazimierza, potem przełożona klasztoru; tamże.

132 Eufrozyna Sanguszkówna, księżna z linii kowelskiej, ż. Jerzego Jakuba Szweryna (zm. 1678 lub 1679); A. Sikorski, Szweryn Jan Ulryk, w: PSB, t. 49, Warszawa-Kraków 2014, s. 485-486.

133 Dotyczy Anny Zawiszanki, ż. Symeona Samuela Sanguszki.

${ }^{134}$ Kazimierz Sanguszko, zm. 1655, ks. z linii kowelskiej, zginął w czasie wojny z Moskwą; M. Nagielski, Sanguszko Samuel Szymon, s. 512 
Syn drugi, Hieronim ${ }^{135}$, ${ }^{k}$ był niemały czas biskupem metońskim i sufraganem wileńskim, potym biskupem smoleńskim. Umarł w Odelsku ${ }^{136}$ anno 1657, jakoś in junio. Pałac w Wilnie na Zarzeczu ${ }^{137}$ na górze ${ }^{138}$ piękny zbudowałk.

Syn trzeci, Jan ${ }^{139}$, ${ }^{k}$ miał za sobą Radziwiłłównę Annę ${ }^{140}$ księżną klecką, z której zostawił syna Hieronima $^{141}$, który żyje szczęśliwie duodennis ad annum 1661, ultima spes domostwa zacnego, i Katarzynę $^{142}$ córkę, która żyje szczęśliwie, nobiles annos mając.

Księżna matka ${ }^{143}$ umarła w Rosi ${ }^{144}$, majętności Jego Mości Pana Jerzego Karola Hlebowicza ${ }^{145}$, starosty żmudzkiego, borysowskiego etc., anno 1659, 6 martii, hora 10 mane $^{k}$.

[8] Potym z woli Bożej pojąłem znowu za małżonkę Helenę Marcybellę Korwinównę Gosiewską ${ }^{146}$,

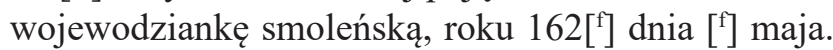

'Roku 1676, in mense januario, książę Jego Mość Hieronim Sanguszko za łaską świętą Boską pojął

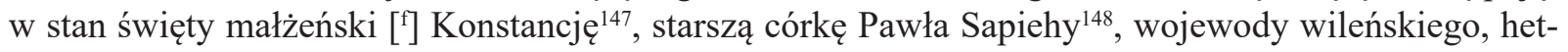
mana litewskiego, i Anny ${ }^{\mathrm{c}} \mathrm{Z}$ domu Kopciównej ${ }^{149}$ córkę, z której czworo dziecic ${ }^{\mathrm{c}}$.

Potomków po sobie zostawił:

Najstarsza córka, Anna ${ }^{150}$, poszła roku 1692 za księcia Jego Mości Radziwiłła ${ }^{151}$ na Ołyce, Nieświeżu i Klecku

Drugi syn, Kazimierz ${ }^{152}\left[{ }^{\mathrm{g}}\right]$

Trzecia córka, Krystyna ${ }^{153}\left[{ }^{\circ}\right]$

Czwarty syn, Pawe ${ }^{154}\left[{ }^{\mathrm{g}}\right]^{1}$

${ }^{135}$ Hieronim Władysław Sanguszko, 1611-1657, ks. z linii kowelskiej, biskup metoneński i sufragan wileński, potem smoleński; B. Kumor, Sanguszko Hieronim Władystaw, s. 482-484.

136 Odelsk, wieś na Białorusi, w obwodzie grodzieńskim, ok. 30 km na południe od Grodna. Hieronim Władysław Sanguszko zm. 5 VII 1657 wskutek zarazy; tamże, s. 484.

137 Zarzecze, część Wilna, na wschód od Starego Miasta, na prawym brzegu rz. Wilejki.

${ }^{138}$ Góra Zbawiciela, wzniesienie na wileńskim Zarzeczu. Barokowy pałac Hieronima Władysława Sanguszki wzniesiono w latach 40. XVII w., na przełomie XVII i XVIII w. wkomponowano go w bryłę kościoła Wniebowstąpienia Pańskiego (misjonarzy); B. Kaczorowski, Zabytki starego Wilna, Warszawa 1991.

139 Jan Władysław Sanguszko, zm. 1652, ks. z linii kowelskiej, starosta suraski, rotmistrz i pułkownik chorągwi husarskiej; M. Nagielski, Sanguszko Samuel Szymon, s. 512.

140 Anna Izabela Radziwiłłówna, zm. 1659, księżna, ż. Jana Władysława Sanguszki; M. Piotrowski, Rodowód książąt Sanguszków Olgierdowiczów, Gumniska 1931, tabl. genealogiczna.

${ }^{141}$ Hieronim Sanguszko, 1649-1684, ks. z linii kowelskiej; tamże.

142 Katarzyna Sanguszkówna, księżna z linii kowelskiej, ż. 1v. Władysława Szmerlinga, 2v. Michała Kryspina Kirszensztajna; tamże.

143 Dotyczy Anny Izabeli Radziwiłłówny.

144 Roś, miasto na Białorusi, w obwodzie grodzieńskim, ok. $60 \mathrm{~km}$ na południowy wchód od Grodna.

145 Jerzy Karol Hlebowicz, 1603-1669, wojewoda smoleński, starosta generalny żmudzki, wojewoda wileński; W. Czapliński, Hlebowicz Jerzy Karol, w: PSB, t. 9, Wrocław 1960-1961, s. 543-544.

${ }^{146}$ Helena Marcybela Korwinówna Gosiewska, zm. 1637, córka wojewody smoleńskiego Aleksandra Gosiewskiego, druga ż. Symeona Samuela Sanguszki, ślub odbył się 6 V 1627 w Wilnie; M. Nagielski, Sanguszko Samuel Szymon, s. 512.

${ }^{147}$ Konstancja Sapieżanka, 1651-1691, od 1676 r. ż. Hieronima Sanguszki; A. Rachuba, Sapieha Pawet Jan, w: PSB, t. 35, s. 147.

148 Paweł Sapieha, 1609-1665, wojewoda witebski i wileński, hetman wielki litewski; tamże, s. 138-148.

149 Anna Barbara Kopeć, 1627-1707, ż. Pawła Sapiehy; tamże, s. 147.

150 Anna Sanguszkówna, 1676-1746, księżna z linii kowelskiej, ż. Karola Stanisława Radziwiłła; A. Rachuba, Radziwiłł Karol Stanisław, w: PSB, t. 30, s. 240-248.

${ }^{151}$ Karol Stanisław Radziwiłł, 1669-1719, ks., stolnik wielki litewski, koniuszy wielki litewski, podkanclerzy i kanclerz wielki litewski; tamże.

152 Kazimierz Antoni Sanguszko, 1677-1706, ks. z linii kowelskiej, marszałek nadworny litewski; R. Marcinek, Sanguszko Kazimierz Antoni, w: PSB, t. 34, s. 496-497.

153 Krystyna Sanguszkówna, zm. 1756, księżna z linii kowelskiej, ż. Władysława Jozafata Sapiehy; A. Rachuba, Sapieha Władysław Jozafat, w: PSB, t. 35, s. 156-158.

154 Paweł Karol Sanguszko, 1680-1750, ks. z linii kowelskiej, podskarbi nadworny litewski, marszałek nadworny i wielki litewski; R. Marcinek, Sanguszko Paweł Karol, w: PSB, t. 34, s. 497-500. 


\section{Genealogy of the Sanguszko Family by Prince Symeon Samuel Sanguszko}

Summary: A genealogy of the Sanguszko Family produced by Symeon Samuel Sanguszko (died 1638) is a short historical text presenting the history of the Sanguszkos in genealogical order: starting with the progenitor, it contains biographic notes of successive members of the family according to family branches. The genealogy made by a member of the family is a record of knowledge of a magnate about his own family, making it a valuable source for research into collective memory and historical culture of magnates of the Polish-Lithuanian Commonwealth of those times. The work is known in three versions: the original and two its eighteenth-century copies. The analysis contains the filiation of known and established manuscript texts, time of their creation, their purpose, and their later archival and library history. Next, the sources of information of the author are established and based on this the historian's craft of the author and the memory culture of his family are discussed. The genealogy was based on historical writings, mainly Maciej Stryjkowski's chronicle, which was used for the reconstruction of the oldest history of the family, and the collective memory of the family, i.e. the knowledge passed down from generation to generation within the family, used to reconstruct the later history. A thorough analysis of the genealogy information revealed that some parts of the work were invented by the author to fill in the gaps between the part reconstructed on the basis of chronicles and that on the basis of family memory ("floating gap"). And finally, the importance of the genealogy for the Sanguszko Family's identity and old-Polish knowledge of genealogy is presented. It turned out that the genealogy had a great impact both on the Sanguszko's identity and the old-Polish genealogical studies, as it gave rise and strengthened the - untrue - conviction among both the family members and old-Polish historians that the Sanguszkos descended from Liubartas son of Gediminas. The annex contains a critical edition of the genealogy text, reconstructed on the basis of three old-Polish manuscripts and a nineteenth-century transcription of the original manuscript.

Notka o Autorze: Jakub Rogulski, mgr historii, doktorant na Wydziale Historycznym Uniwersytetu Jagiellońskiego, pod kierunkiem prof. Zenona Piecha pisze pracę na temat manifestacji splendoru rodowego Sanguszków w epoce nowożytnej. W latach 2014-2016 główny wykonawca grantu Narodowego Centrum Nauki: „Pamięć o dynastycznym pochodzeniu litewskich rodów książęcych w XV-XVIII w."; laureat programu Ministerstwa Nauki i Szkolnictwa Wyższego „Mobilność Plus”, dzięki któremu w 2018 r. odbył staż na Uniwersytecie w Lejdzie pod kierunkiem prof. Jeroena Duindama. Autor kilkunastu artykułów naukowych opublikowanych w czasopismach polskich, angielskich i ukraińskich.

Author: Jakub Rogulski, MA, PhD candidate of the Faculty of History at the Jagiellonian University; under Prof. Zenon Piech he writes a thesis on the family splendour of the Sanguszkos in the early modern era. In 2014-2016 the principal investigator of the National Science Centre grant: "Memory of dynastic origin of Lithuanian ducal families in the fifteenth to eighteenth centuries"; a laureate of the Ministry of Science and Higher Education programme "Mobilność Plus", which enabled him in 2018 to go to internship at the University of Leiden under Prof. Jeroen Duindam. The author of a dozen or so scholarly articles in Polish, English, and Ukrainian journals.

Wydział Historyczny Uniwersytetu Jagiellońskiego

ul. Gołębia 24

31-007 Kraków

e-mail: jakub.rogulski@gmail.com

\section{Bibliografia}

\section{Źródła}

Bielski J., Kronika polska Marcina Bielskiego nowo przez Joachima Bielskiego syna jego wydana, Kraków 1597 Dygoń T., Przemiana koni poszosnych pod lektykę [...] Symeona Samuela Lubartowicza Sanguszka, [Wilno] 1639 Głuchowski J., Philosophia universa honori et gloriae immortali [...] Casimiri Iosephi Antonii Sanguszko, Warszawa 1689

Hączel Mokrski A., Pogonia żałobna [...] Symeona Samuela Lubartowicza Sanguszka, Wilno 1639

Katalog rękopisów archiwum XX. Sanguszków w Sławucie, oprac. B. Gorczak, Sławuta 1902 
Kojałowicz-Wijuk W., Herbarz rycerstwa W. X. Litewskiego tak zwany Compendium czyli o klejnotach albo herbach których familie stanu rycerskiego w prowincyach Wielkiego Xięstwa Litewskiego zażywają, wyd. F. Piekosiński, Herold Polski, Kraków 1897

Kojałowicz-Wijuk W., Herbarz szlachty Wielkiego Księstwa Litewskiego zwany Nomenclator, wyd. F. Piekosiński, Herold Polski, Kraków 1905

Korespondencja Józefa Andrzeja Załuskiego 1724-1736, oprac. B.S. Kupść, K. Muszyńska, Wrocław-Warszawa-Kraków 1967

Niesiecki K., Herbarz polski, t. 8, wyd. J.N. Bobrowicz, Lipsk 1841

Okolski S., Orbis Polonus, t. 1-3, Kraków 1641-1645

Paprocki B., Gniazdo cnoty, skąd herby rycerstwa sławnego Królestwa Polskiego, Wielkiego Księstwa Litewskiego, Kraków 1578

Paprocki B., Herby rycerstwa polskiego, wyd. K.J. Turowski, Kraków 1858

Stryjkowski M., Która przedtym nigdy świata nie widziała kronika polska, litewska, żmódzka i wszystkiej Rusi kijowskiej, moskiewskiej, siewierskiej, wołyńskiej, podolskiej, podgorskiej, podlaskiej etc., Królewiec 1582 (nowe wyd.: Kronika polska, litewska, żmódzka i wszystkiej Rusi Macieja Stryjkowskiego, t. 1-2, Warszawa 1846)

Susza J., Phoenix redivivus albo obraz starożytny chetmski Panny Matki Przenaświętszej, Zamość 1646

Testamenty książą Lubartowiczów-Sanguszków. Wybór tekstów źródłowych z lat 1750-1876, wyd. J.M. Marszalska, W. Graczyk, Kraków 2011

Zapiski z wycieczek po kraju, „Czas”, 30 VII 1852, s. 1-2; 31 VII 1852, s. 1-2

\section{Opracowania}

Assmann J., Pamięć kulturowa. Pismo, zapamiętywanie i polityczna tożsamość w cywilizacjach starożytnych, tłum. A. Kryczyńska-Pham, wstęp i red. R. Traba, wyd. 2, Warszawa 2015

Chłapowski K., Starostowie niegrodowi w Koronie 1565-1795 (Materiały źródłowe), Warszawa 2017

Dacka I., „, Korona polska” Kaspra Niesieckiego. Pomnik staropolskiego piśmiennictwa heraldycznego, Warszawa 2004

Dąbrowski D., Rodowód Romanowiczów książąt halicko-wołyńskich, Poznań-Wrocław 2002

Grala J., Kolekcja Michała Marczaka w zbiorach Archiwum Głównego Akt Dawnych, „Miscellanea Historico-Archivistica", 4, 1994, s. 228-232

Halbwachs M., Społeczne ramy pamięci, tłum. i wstęp M. Król, Warszawa 1969

Karkucińska W., Anna z Sanguszków Radziwiłłowa (1676-1746). Działalność gospodarcza i mecenat, Warszawa 2000

Kozicki Z.D., W sprawie rodowodu X. X. Sanguszków, w: Sprawa początków rodu XX. Sanguszków, Lwów 1901, s. 64

Kuklo C., Demografia Rzeczypospolitej przedrozbiorowej, Warszawa 2011

Marszalska J.M., Biblioteka i archiwum Sanguszków. Zarys dziejów, Tarnów 2000

Marszalska J.M., Fundacje i życie religijne książąt Lubartowiczów-Sanguszków linii koszyrskiej i kowelskiej na przełomie XVII i XVIII stulecia, w: Veritati serviens. Księga pamiątkowa Ojcu Profesorowi Januszowi Zbudniewkowi zp, Warszawa 2009, s. 203-224

Monografia XX. Sanguszków oraz innych potomków Lubarta-Fedora Olgerdowicza x. ratneńskiego, t. 1, oprac. Z.L. Radzimiński, Lwów 1906; t. 2: Linia niesuchojeżska, cz. 1-2, oprac. Z.L. Radzimiński, Lwów 1911-1933; t. 3: Gałaź koszyrska, oprac. B. Gorczak, Lwów 1906

Nestorow R., Smolany Sanguszków w świetle inwentarzy i nieznanych materiatów archiwalnych, w: Wokót Sanguszków. Dzieje - sztuka - kultura. Materiały I Ogólnopolskiej Konferencji Naukowej, 29-30 czerwiec 2006, Ratusz, Muzeum Okręgowe w Tarnowie, red. J. Skrabski, B. Bułdys, Tarnów 2007, s. 109-117

Paszkiewicz H., Polityka ruska Kazimierza Wielkiego, wyd. 2, Kraków 2002

Piotrowski M., Rodowód książąt Sanguszków Olgierdowiczów, tablica genealogiczna, Gumniska 1931

Polski słownik biograficzny, t. 1-49, Wrocław-Warszawa-Kraków 1935-1994 (zwłaszcza t. 34, zawierający biogramy Sanguszków)

Radzimiński Z.L., Wstępne słowo do monografii xięcia Fedora Olgerdowicza Ratneńskiego i jego potomków, w: Sprawa początków rodu XX. Sanguszków, Lwów 1901, s. 3-4

Radziszewski F., Wiadomości historyczno-statystyczne o znakomitych bibliotekach $i$ archiwach publicznych i prywatnych tak niegdyś bylych jako i obecnie istniejacych, Kraków 1875

Rogulski J., ,, Gutullae sanguinis Iagellonici”. Jagiellonian Identity among the Princes of Poland-Lithuania in the Early Modern Period, „Canadian-American Slavic Studies”, 52, 2018, nr 2 (w druku) 
Rogulski J., Memory of Social Elites. What Should not be Forgotten. The Case of the Lithuanian Princes in the Sixteenth to Eighteenth Centuries, „Court Historian”, 22, 2017, nr 2, s. 189-210

Rogulski J., Nowożytny ród szlachecki jako „,wspólnota pamięci”. Przypadek książą Sanguszków (XV-XVIII w.), Przegl. Hist., 108, 2017, nr 3, s. 491-530

Rogulski J., Treści propagandowe herbu złożonego księcia Szymona Samuela Sanguszki z 1626 roku, w: Insignia et splendor. Heraldyka w stużbie rodów szlacheckich i instytucji Kościoła, red. W. Drelicharz, Kraków 2011, s. 9-84

Seroka H., Geneza i symbolika herbu Lubartowa, w: Lubartów i ziemia lubartowska, red. W. Śladkowski, B. Gąsior, Lubartów 1993, s. 33-39

Sokołowski M., Miniatury włoskie Biblioteki Jagiellońskiej i modlitewnik francuski ks. Samuela Sanguszki w bibliotece dzikowskiej, Kraków 1892

Stadnicki K., Synowie Gedymina, t. 2: Lubart xiąże wotyński, Lwów 1853

Syta K., Dzieje archiwum książąt Sanguszków, „Miscellanea Historico-Archivistica”, 11, 2000, s. 97-110

Tęgowski J., Pierwsze pokolenia Giedyminowiczów, Poznań-Wrocław 1999

Thomas K., Vergangenheit, Zukunft, Lebensalter. Zeitvorstellungen in England der früher Neuzeit, Berlin 1988

Wolff J., Kniaziowie litewsko-ruscy od końca czternastego wieku, Warszawa 1895

Wolff J., Ród Gedimina. Dodatki i poprawki do dzieł hr. K. Stadnickiego „,Synowie Gedymina”, „,Olgierd i Kiejstut” i „Bracia Władystawa Jagietty”, Kraków 1886

Zagórska S., Halszka z Ostroga. Między faktami a mitami, Warszawa 2006

Zajączkowski S., Przyczynki do hipotezy o pochodzeniu dynastii Giedymina ze Żmudzi, „Ateneum Wileńskie”, 4, 1927, s. 392-416

Zielińska T., Poczet polskich rodów arystokratycznych, Warszawa 1997

Żychliński T., Zlota księga szlachty polskiej, t. 5, Poznań 1883 